\title{
Class A Orphans (version 2019.5) in the IUPHAR/BPS Guide to Pharmacology Database
}

\author{
Stephen P.H. Alexander ${ }^{1}$, Jim Battey ${ }^{2}$, Helen E. Benson ${ }^{3}$, Richard V. Benya ${ }^{4}$, Tom I. Bonner ${ }^{5}$, Anthony P. \\ Davenport $^{6}$, Satoru Eguchi ${ }^{7}$, Anthony Harmar ${ }^{3}$, Nick Holliday ${ }^{1}$, Robert T. Jensen ${ }^{2}$, Sadashiva Karnik ${ }^{8}$, Evi \\ Kostenis $^{9}$, Wen Chiy Liew ${ }^{3}$, Amy E. Monaghan ${ }^{3}$, Chido Mpamhanga ${ }^{10}$, Richard Neubig ${ }^{11}$, Adam J. Pawson ${ }^{3}$, \\ Jean-Philippe Pin ${ }^{12}$, Joanna L. Sharman ${ }^{3}$, Michael Spedding ${ }^{13}$, Eliot Spindel ${ }^{14}$, Leigh Stoddart ${ }^{15}$, Laura \\ Storjohann ${ }^{16}$, Walter G. Thomas ${ }^{17}$, Kalyan Tirupula ${ }^{8}$ and Patrick Vanderheyden ${ }^{18}$ \\ 1. University of Nottingham, UK \\ 2. National Institutes of Health, USA \\ 3. University of Edinburgh, UK \\ 4. University of Illinois at Chicago, USA \\ 5. National Institute of Mental Health, USA \\ 6. University of Cambridge, UK \\ 7. Temple University, USA \\ 8. Cleveland Clinic Lerner Research Institute, USA \\ 9. University of Bonn, Germany \\ 10. LifeArc, UK \\ 11. Michigan State University, USA \\ 12. Université de Montpellier, France \\ 13. Spedding Research Solutions SARL, France \\ 14. Oregon Health \& Science University, USA \\ 15. University of Glasgow, UK \\ 16. University of Utah, USA \\ 17. University of Queensland, Australia \\ 18. Vrije Universiteit Brussel, Belgium
}

\section{Abstract}

Table 1 lists a number of putative GPCRs identified byNC-IUPHAR [194], for which preliminary evidence for an endogenous ligand has been published, or for which there exists a potential link to a disease, or disorder. These GPCRs have recently been reviewed in detail [150]. The GPCRs in Table 1 are all Class A, rhodopsin-like GPCRs. Class A orphan GPCRs not listed in Table 1 are putative GPCRs with as-yet unidentified endogenous ligands.

Table 1: Class A orphan GPCRs with putative endogenous ligands

$\begin{array}{llllll}\text { GPR3 GPR4 } & \text { GPR6 } & \text { GPR12 } & \text { GPR15 } & \text { GPR17 } & \text { GPR20 } \\ \text { GPR22 GPR26 } & \text { GPR31 } & \text { GPR34 } & \text { GPR35 } & \text { GPR37 } & \text { GPR39 } \\ \text { GPR50 GPR63 } & \text { GRP65 } & \text { GPR68 } & \text { GPR75 } & \text { GPR84 } & \text { GPR87 } \\ \text { GPR88 GPR132 GPR149 } & \text { GPR161 } & \text { GPR183 } & \text { LGR4 } & \text { LGR5 }\end{array}$

In addition the orphan receptors GPR18, GPR55 and GPR119 which are reported to respond to endogenous agents analogous to the endogenous cannabinoid ligands have been grouped together (GPR18, GPR55 and GPR119). 


\section{Contents}

This is a citation summary for Class A Orphans in the Guide to Pharmacology database (GtoPdb). It exists purely as an adjunct to the database to facilitate the recognition of citations to and from the database by citation analyzers. Readers will almost certainly want to visit the relevant sections of the database which are given here under database links.

GtoPdb is an expert-driven guide to pharmacological targets and the substances that act on them. GtoPdb is a reference work which is most usefully represented as an on-line database. As in any publication this work should be appropriately cited, and the papers it cites should also be recognized. This document provides a citation for the relevant parts of the database, and also provides a reference list for the research cited by those parts.

Please note that the database version for the citations given in GtoPdb are to the most recent preceding version in which the family or its subfamilies and targets were substantially changed. The links below are to the current version. If you need to consult the cited version, rather than the most recent version, please contact the GtoPdb curators.

\section{Database links}

\section{Class A Orphans}

http://www.guidetopharmacology.org/GRAC/FamilyDisplayForward?familyld=16 Introduction to Class A Orphans

http://www.guidetopharmacology.org/GRAC/FamilyIntroductionForward?familyld=16

Receptors

$\mathrm{BB}_{3}$ receptor

http://www.guidetopharmacology.org/GRAC/ObjectDisplayForward?objectld=40 GPR3

http://www.guidetopharmacology.org/GRAC/ObjectDisplayForward?objectld=83 GPR4

http://www.guidetopharmacology.org/GRAC/ObjectDisplayForward?objectld=84 GPR6

http://www.guidetopharmacology.org/GRAC/ObjectDisplayForward?objectld=85 GPR42

http://www.guidetopharmacology.org/GRAC/ObjectDisplayForward?objectld=228 GPR12

http://www.guidetopharmacology.org/GRAC/ObjectDisplayForward?objectld=86 GPR15

http://www.guidetopharmacology.org/GRAC/ObjectDisplayForward?objectld=87 GPR17

http://www.guidetopharmacology.org/GRAC/ObjectDisplayForward?objectld=88 GPR18

http://www.guidetopharmacology.org/GRAC/ObjectDisplayForward?objectld=89 GPR19

http://www.guidetopharmacology.org/GRAC/ObjectDisplayForward?objectld=90 GPR20

http://www.guidetopharmacology.org/GRAC/ObjectDisplayForward?objectld=91 GPR21

http://www.guidetopharmacology.org/GRAC/ObjectDisplayForward?objectld=92 GPR22

http://www.guidetopharmacology.org/GRAC/ObjectDisplayForward?objectld=93 GPR25

http://www.guidetopharmacology.org/GRAC/ObjectDisplayForward?objectld=95 GPR26

http://www.guidetopharmacology.org/GRAC/ObjectDisplayForward?objectld=96 GPR27

http://www.guidetopharmacology.org/GRAC/ObjectDisplayForward?objectld=97 GPR31 
http://www.guidetopharmacology.org/GRAC/ObjectDisplayForward?objectld=98 GPR32

http://www.guidetopharmacology.org/GRAC/ObjectDisplayForward?objectld=99 GPR33

http://www.guidetopharmacology.org/GRAC/ObjectDisplayForward?objectld=100 GPR34

http://www.guidetopharmacology.org/GRAC/ObjectDisplayForward?objectld=101 GPR35

http://www.guidetopharmacology.org/GRAC/ObjectDisplayForward?objectld=102 GPR37

http://www.guidetopharmacology.org/GRAC/ObjectDisplayForward?objectld=103 GPR37L1

http://www.guidetopharmacology.org/GRAC/ObjectDisplayForward?objectld=104 GPR39

http://www.guidetopharmacology.org/GRAC/ObjectDisplayForward?objectld=105 GPR45

http://www.guidetopharmacology.org/GRAC/ObjectDisplayForward?objectld=106 GPR50

http://www.guidetopharmacology.org/GRAC/ObjectDisplayForward?objectld=107 GPR52

http://www.guidetopharmacology.org/GRAC/ObjectDisplayForward?objectld=108 GPR55

http://www.guidetopharmacology.org/GRAC/ObjectDisplayForward?objectld=109 GPR61

http://www.guidetopharmacology.org/GRAC/ObjectDisplayForward?objectld=110 GPR62

http://www.guidetopharmacology.org/GRAC/ObjectDisplayForward?objectld=111 GPR63

http://www.guidetopharmacology.org/GRAC/ObjectDisplayForward?objectld=112 GPR65

http://www.guidetopharmacology.org/GRAC/ObjectDisplayForward?objectld=113 GPR68

http://www.guidetopharmacology.org/GRAC/ObjectDisplayForward?objectld=114 GPR75

http://www.guidetopharmacology.org/GRAC/ObjectDisplayForward?objectld=115 GPR78

http://www.guidetopharmacology.org/GRAC/ObjectDisplayForward?objectld=116 GPR79

http://www.guidetopharmacology.org/GRAC/ObjectDisplayForward?objectld=117 GPR82

http://www.guidetopharmacology.org/GRAC/ObjectDisplayForward?objectld=118 GPR83

http://www.guidetopharmacology.org/GRAC/ObjectDisplayForward?objectld=119 GPR84

http://www.guidetopharmacology.org/GRAC/ObjectDisplayForward?objectld=120 GPR85

http://www.guidetopharmacology.org/GRAC/ObjectDisplayForward?objectld=121 GPR87

http://www.guidetopharmacology.org/GRAC/ObjectDisplayForward?objectld=122 GPR88

http://www.guidetopharmacology.org/GRAC/ObjectDisplayForward?objectld=123 GPR101

http://www.guidetopharmacology.org/GRAC/ObjectDisplayForward?objectld=125 GPR119

http://www.guidetopharmacology.org/GRAC/ObjectDisplayForward?objectld=126 GPR132

http://www.guidetopharmacology.org/GRAC/ObjectDisplayForward?objectld=128 GPR135 
http://www.guidetopharmacology.org/GRAC/ObjectDisplayForward?objectld=129 GPR139

http://www.guidetopharmacology.org/GRAC/ObjectDisplayForward?objectld=130 GPR141

http://www.guidetopharmacology.org/GRAC/ObjectDisplayForward?objectld=131 GPR142

http://www.guidetopharmacology.org/GRAC/ObjectDisplayForward?objectld=132 GPR146

http://www.guidetopharmacology.org/GRAC/ObjectDisplayForward?objectld=133 GPR148

http://www.guidetopharmacology.org/GRAC/ObjectDisplayForward?objectld=134 GPR149

http://www.guidetopharmacology.org/GRAC/ObjectDisplayForward?objectld=135 GPR150

http://www.guidetopharmacology.org/GRAC/ObjectDisplayForward?objectld=136 GPR151

http://www.guidetopharmacology.org/GRAC/ObjectDisplayForward?objectld=137 GPR152

http://www.guidetopharmacology.org/GRAC/ObjectDisplayForward?objectld=138 GPR153

http://www.guidetopharmacology.org/GRAC/ObjectDisplayForward?objectld=139 GPR160

http://www.guidetopharmacology.org/GRAC/ObjectDisplayForward?objectld=140 GPR161

http://www.guidetopharmacology.org/GRAC/ObjectDisplayForward?objectld=141 GPR162

http://www.guidetopharmacology.org/GRAC/ObjectDisplayForward?objectld=142 GPR171

http://www.guidetopharmacology.org/GRAC/ObjectDisplayForward?objectld=143 GPR173

http://www.guidetopharmacology.org/GRAC/ObjectDisplayForward?objectld=144 GPR174

http://www.guidetopharmacology.org/GRAC/ObjectDisplayForward?objectld=145 GPR176

http://www.guidetopharmacology.org/GRAC/ObjectDisplayForward?objectld=637 GPR182

http://www.guidetopharmacology.org/GRAC/ObjectDisplayForward?objectld=146 GPR183

http://www.guidetopharmacology.org/GRAC/ObjectDisplayForward?objectld=81 LGR4

http://www.guidetopharmacology.org/GRAC/ObjectDisplayForward?objectld=147 LGR5

http://www.guidetopharmacology.org/GRAC/ObjectDisplayForward?objectld=148 LGR6

http://www.guidetopharmacology.org/GRAC/ObjectDisplayForward?objectld=149 MAS1

http://www.guidetopharmacology.org/GRAC/ObjectDisplayForward?objectld=150 MAS1L

http://www.guidetopharmacology.org/GRAC/ObjectDisplayForward?objectld=151 MRGPRD

http://www.guidetopharmacology.org/GRAC/ObjectDisplayForward?objectld=152 MRGPRE

http://www.guidetopharmacology.org/GRAC/ObjectDisplayForward?objectld=153 MRGPRF

http://www.guidetopharmacology.org/GRAC/ObjectDisplayForward?objectld=154 MRGPRG

http://www.guidetopharmacology.org/GRAC/ObjectDisplayForward?objectld=155 MRGPRX1 
http://www.guidetopharmacology.org/GRAC/ObjectDisplayForward?objectld=156 MRGPRX2

http://www.guidetopharmacology.org/GRAC/ObjectDisplayForward?objectld=157 MRGPRX3

http://www.guidetopharmacology.org/GRAC/ObjectDisplayForward?objectld=158 MRGPRX4

http://www.guidetopharmacology.org/GRAC/ObjectDisplayForward?objectld=159 P2RY8

http://www.guidetopharmacology.org/GRAC/ObjectDisplayForward?objectld=164 P2RY10

http://www.guidetopharmacology.org/GRAC/ObjectDisplayForward?objectld=165

\section{TAAR2}

http://www.guidetopharmacology.org/GRAC/ObjectDisplayForward?objectld=167 TAAR3

http://www.guidetopharmacology.org/GRAC/ObjectDisplayForward?objectld=168 TAAR4P

http://www.guidetopharmacology.org/GRAC/ObjectDisplayForward?objectld=169 TAAR5

http://www.guidetopharmacology.org/GRAC/ObjectDisplayForward?objectld=170 TAAR6

http://www.guidetopharmacology.org/GRAC/ObjectDisplayForward?objectld=171 TAAR8

http://www.guidetopharmacology.org/GRAC/ObjectDisplayForward?objectld=172 TAAR9

http://www.guidetopharmacology.org/GRAC/ObjectDisplayForward?objectld=173

\section{References}

1. (2006) Retraction. Sphingosylphosphorylcholine is a ligand for ovarian cancer G-protein-coupled receptor 1. Nat. Cell Biol. 8: 299 [PMID:16508674]

2. Aalto Y, El-Rifa W, Vilpo L, Ollila J, Nagy B, Vihinen M, Vilpo J and Knuutila S. (2001) Distinct gene expression profiling in chronic lymphocytic leukemia with 11q23 deletion. Leukemia 15: 1721-8 [PMID:11681413]

3. Adams F, Grassie M, Shahid M, Hill DR and Henry B. (2003) Acute oral dexamethasone administration reduces levels of orphan GPCR glucocorticoid-induced receptor (GIR) mRNA in rodent brain: potential role in HPA-axis function. Brain Res. Mol. Brain Res. 117: 39-46 [PMID:14499479]

4. Adams JW, Wang J, Davis JR, Liaw C, Gaidarov I, Gatlin J, Dalton ND, Gu Y, Ross J, Behan D, Chien K and Connolly D. (2008) Myocardial expression, signaling, and function of GPR22: a protective role for an orphan G protein-coupled receptor. Am. J. Physiol. Heart Circ. Physiol.295: H509-21 [PMID:18539757]

5. Adrian K, Bernhard MK, Breitinger HG and Ogilvie A. (2000) Expression of purinergic receptors (ionotropic P2X1-7 and metabotropic P2Y1-11) during myeloid differentiation of HL60 cells. Biochim. Biophys. Acta 1492: 127-38 [PMID:11004484]

6. Afrasiabi E, Blom T, Ekokoski E, Tuominen RK and Törnquist K. (2006) Sphingosylphosphorylcholine enhances calcium entry in thyroid FRO cells by a mechanism dependent on protein kinase C. Cell. Signal. 18: 1671-8 [PMID:16490345]

7. Agrawal A and Lynskey MT. (2009) Candidate genes for cannabis use disorders: findings, challenges and directions. Addiction 104: 518-32 [PMID:19335651]

8. Alaerts M, Venken T, Lenaerts AS, De Zutter S, Norrback KF, Adolfsson R and Del-Favero J. (2006) Lack of association of an insertion/deletion polymorphism in the $\mathrm{G}$ protein-coupled receptor 50 with bipolar disorder in a Northern Swedish population. Psychiatr. Genet. 16: 235-6 [PMID:17106423]

9. Albright AV, Shieh JT, Itoh T, Lee B, Pleasure D, O'Connor MJ, Doms RW and González-Scarano F. (1999) Microglia express CCR5, CXCR4, and CCR3, but of these, CCR5 is the principal coreceptor for human immunodeficiency virus type 1 dementia isolates. J. Virol.73: 205-13 [PMID:9847323]

10. Alenina N, Bader M and Walther T. (2002) Imprinting of the murine MAS protooncogene is restricted to its antisense RNA. Biochem. Biophys. Res. Commun. 290: 1072-8 [PMID:11798184]

11. Alenina N, Baranova T, Smirnow E, Bader M, Lippoldt A, Patkin E and Walther T. (2002) Cell type-specific expression of the Mas proto-oncogene in testis. J. Histochem. Cytochem. 50: 691-6 [PMID:11967280]

12. Alexander SP. (2012) So what do we call GPR18 now?Br. J. Pharmacol. 165: 2411-3 [PMID:22014123] 
13. Ali H. (2016) Mas-related G protein coupled receptor-X2: A potential new target for modulating mast cellmediated allergic and inflammatory diseases. J Immunobio/ 1: [PMID:28090599]

14. Ali S, Lamont BJ, Charron MJ and Drucker DJ. (2011) Dual elimination of the glucagon and GLP-1 receptors in mice reveals plasticity in the incretin axis. J. Clin. Invest. 121: 1917-29 [PMID:21540554]

15. Allia E, Tarabra E, Volante M, Cerrato M, Ghigo E, Muccioli G and Papotti M. (2005) Expression of cortistatin and MrgX2, a specific cortistatin receptor, in human neuroendocrine tissues and related tumours. J. Pathol. 207: 336-45 [PMID:16161007]

16. Alper P, Azimioara M, Cow C, Mutnick D, Nikulin V, Michellys PY, Wang Z, Reding E, Paliotti M and Li kt al.. (2014) Discovery of structurally novel, potent and orally efficacious GPR119 agonists.Bioorg. Med. Chem. Lett. 24: 2383-7 [PMID:24751443]

17. Amann D, Avidan N, Kanyas K, Kohn Y, Hamdan A, Ben-Asher E, Macciardi F, Beckmann JS, Lancet D and Lerer B. (2006) The trace amine receptor 4 gene is not associated with schizophrenia in a sample linked to chromosome 6q23. Mol. Psychiatry 11: 119-21 [PMID:16189505]

18. Ambroz C, Clark AJ and Catt KJ. (1991) The mas oncogene enhances angiotensin-induced [Ca2+]i responses in cells with pre-existing angiotensin II receptors. Biochim. Biophys. Acta1133: 107-11 [PMID:1721543]

19. Amisten S, Braun OO, Bengtsson A and Erlinge D. (2008) Gene expression profiling for the identification of G-protein coupled receptors in human platelets. Thromb. Res. 122: 47-57 [PMID:17920662]

20. Amoh Y, Aki R, Hamada Y, Niiyama S, Eshima K, Kawahara K, Sato Y, Tani Y, Hoffman RM and Katsuoka K. (2012) Nestin-positive hair follicle pluripotent stem cells can promote regeneration of impinged peripheral nerve injury. J. Dermatol. 39: 33-8 [PMID:22098554]

21. An S, Tsai C and Goetzl EJ. (1995) Cloning, sequencing and tissue distribution of two related G proteincoupled receptor candidates expressed prominently in human lung tissue. FEBS Lett. 375: 121-4 [PMID:7498459]

22. Anavi-Goffer S, Baillie G, Irving AJ, Gertsch J, Greig IR, Pertwee RG and Ross RA. (2012) Modulation of L- $\alpha$-lysophosphatidylinositol/GPR55 mitogen-activated protein kinase (MAPK) signaling by cannabinoids. J. Biol. Chem. 287: 91-104 [PMID:22027819]

23. Andradas C, Caffarel MM, Pérez-Gómez E, Salazar M, Lorente M, Velasco G, Guzmán M and Sánchez C. (2011) The orphan G protein-coupled receptor GPR55 promotes cancer cell proliferation via ERK. Oncogene 30: 245-52 [PMID:20818416]

24. Aoki K, Sun YJ, Aoki S, Wada K and Wada E. (2002) Cloning, expression, and mapping of a gene that is upregulated in adipose tissue of mice deficient in bombesin receptor subtype-3. Biochem. Biophys. Res. Commun. 290: 1282-8 [PMID:11812002]

25. Arumugam S, Thandavarayan RA, Palaniyandi SS, Giridharan VV, Arozal W, Sari FR, Soetikno V, Harima M, Suzuki K and Kodama M et al.. (2012) Candesartan cilexetil protects from cardiac myosin induced cardiotoxicity via reduction of endoplasmic reticulum stress and apoptosis in rats: involvement of ACE2Ang (1-7)-mas axis. Toxicology 291: 139-45 [PMID:22120037]

26. Assou S, Le Carrour T, Tondeur S, Ström S, Gabelle A, Marty S, Nadal L, Pantesco V, Réme T, Hugnot JP, Gasca S, Hovatta O, Hamamah S, Klein B and De Vos J. (2007) A meta-analysis of human embryonic stem cells transcriptome integrated into a web-based expression atlas. Stem Cells 25: 961-73 [PMID:17204602]

27. Avula LR, Buckinx R, Alpaerts K, Costagliola A, Adriaensen D, Van Nassauw L and Timmermans JP. (2011) The effect of inflammation on the expression and distribution of the MAS-related gene receptors MrgE and MrgF in the murine ileum. Histochem. Cell Biol. 136: 569-85 [PMID:21912971]

28. Azimi E, Reddy VB and Lerner EA. (2017) Brief communication: MRGPRX2, atopic dermatitis and red man syndrome. Itch (Phila) 2: [PMID:28367504]

29. Azimi E, Reddy VB, Shade KC, Anthony RM, Talbot S, Pereira PJ and Lerner EA. (2016) Dual action of neurokinin-1 antagonists on Mas-related GPCRs. JCl Insight 1: e89362 [PMID:27734033]

30. Azimioara M, Alper P, Cow C, Mutnick D, Nikulin V, Lelais G, Mecom J, McNeill M, Michellys PY and Wang $Z$ et al.. (2014) Novel tricyclic pyrazolopyrimidines as potent and selective GPR119 agonists.Bioorg. Med. Chem. Lett. 24: 5478-83 [PMID:25455488]

31. Bab I, Smoum R, Bradshaw H and Mechoulam R. (2011) Skeletal lipidomics: regulation of bone metabolism by fatty acid amide family. Br. J. Pharmacol. 163: 1441-6 [PMID:21557736]

32. Badolato M, Carullo G, Caroleo MC, Cione E, Aiello F and Manetti F. (2019) Discovery of 1,4Naphthoquinones as a New Class of Antiproliferative Agents Targeting GPR55 ACS Medicinal Chemistry Letters

33. Baens M, Finalet Ferreiro J, Tousseyn T, Urbankova H, Michaux L, de Leval L, Dierickx D, Wolter $P$, Sagaert $X$ and Vandenberghe $P$ et al.. (2012) $t(X ; 14)(p 11.4 ; q 32.33)$ is recurrent in marginal zone 
lymphoma and up-regulates GPR34. Haematologica 97: 184-8 [PMID:22058210]

34. Baker D, Pryce G, Davies WL and Hiley CR. (2006) In silico patent searching reveals a new cannabinoid receptor. Trends Pharmacol. Sci. 27: 1-4 [PMID:16318877]

35. Balabanian K, Lagane B, Infantino S, Chow KY, Harriague J, Moepps B, Arenzana-Seisdedos F, Thelen M and Bachelerie F. (2005) The chemokine SDF-1/CXCL12 binds to and signals through the orphan receptor RDC1 in T lymphocytes. J. Biol. Chem. 280: 35760-6 [PMID:16107333]

36. Balenga NA, Aflaki E, Kargl J, Platzer W, Schröder R, Blättermann S, Kostenis E, Brown AJ, Heinemann A and Waldhoer M. (2011) GPR55 regulates cannabinoid 2 receptor-mediated responses in human neutrophils. Cell Res. 21: 1452-69 [PMID:21467997]

37. Bang S, Xie YK, Zhang ZJ, Wang Z, Xu ZZ and Ji RR. (2018) GPR37 regulates macrophage phagocytosis and resolution of inflammatory pain. J. Clin. Invest. 128: 3568-3582 [PMID:30010619]

38. Barker N and Clevers H. (2010) Leucine-rich repeat-containing G-protein-coupled receptors as markers of adult stem cells. Gastroenterology 138: 1681-96 [PMID:20417836]

39. Barrett P, Ivanova E, Graham ES, Ross AW, Wilson D, Plé H, Mercer JG, Ebling FJ, Schuhler S, Dupré SM, Loudon A and Morgan PJ. (2006) Photoperiodic regulation of cellular retinol binding protein, CRBP1 [corrected] and nestin in tanycytes of the third ventricle ependymal layer of the Siberian hamster. J. Endocrinol. 191: 687-98 [PMID:17170225]

40. Barrowcliffe TW, Gutteridge JM and Dormandy TL. (1975) The effect of fatty-acid autoxidation products on blood coagulation. Thromb Diath Haemorrh 33: 271-7 [PMID:1138422]

41. Bassilana F, Carlson A, DaSilva JA, Grosshans B, Vidal S, Beck V, Wilmeringwetter B, Llamas LA, Showalter TB and Rigollier $P$ et al.. (2014) Target identification for a Hedgehog pathway inhibitor reveals the receptor GPR39. Nat. Chem. Biol. 10: 343-9 [PMID:24633354]

42. Batailler M, Mullier A, Sidibe A, Delagrange P, Prévot V, Jockers R and Migaud M. (2012) Neuroanatomical distribution of the orphan GPR50 receptor in adult sheep and rodent brains. $J$. Neuroendocrinol. 24: 798-808 [PMID:22512326]

43. Bates B, Zhang L, Nawoschik S, Kodangattil S, Tseng E, Kopsco D, Kramer A, Shan Q, Taylor N, Johnson J, Sun Y, Chen HM, Blatcher M, Paulsen JE and Pausch MH. (2006) Characterization of Gpr101 expression and G-protein coupling selectivity. Brain Res. 1087: 1-14 [PMID:16647048]

44. Bechtold DA, Sidibe A, Saer BR, Li J, Hand LE, Ivanova EA, Darras VM, Dam J, Jockers R and Luckman SM et al.. (2012) A role for the melatonin-related receptor GPR50 in leptin signaling, adaptive thermogenesis, and torpor. Curr. Biol. 22: 70-7 [PMID:22197240]

45. Becker JA, Befort K, Blad C, Filliol D, Ghate A, Dembele D, Thibault C, Koch M, Muller J, Lardenois A, Poch $\mathrm{O}$ and Kieffer BL. (2008) Transcriptome analysis identifies genes with enriched expression in the mouse central extended amygdala. Neuroscience 156: 950-65 [PMID:18786617]

46. Befort K, Filliol D, Ghate A, Darcq E, Matifas A, Muller J, Lardenois A, Thibault C, Dembele D, Le Merrer J, Becker JA, Poch O and Kieffer BL. (2008) Mu-opioid receptor activation induces transcriptional plasticity in the central extended amygdala. Eur. J. Neurosci. 27: 2973-84 [PMID:18588537]

47. Bektas M, Barak LS, Jolly PS, Liu H, Lynch KR, Lacana E, Suhr KB, Milstien S and Spiegel S. (2003) The G protein-coupled receptor GPR4 suppresses ERK activation in a ligand-independent manner.

Biochemistry 42: 12181-91 [PMID:14567679]

48. Bender E, Buist A, Jurzak M, Langlois X, Baggerman G, Verhasselt P, Ercken M, Guo HQ, Wintmolders C and Van den Wyngaert I et al.. (2002) Characterization of an orphan $G$ protein-coupled receptor localized in the dorsal root ganglia reveals adenine as a signaling molecule. Proc. Natl. Acad. Sci. U.S.A.99: 8573-8 [PMID:12084918]

49. Benned-Jensen T and Rosenkilde MM. (2008) Structural motifs of importance for the constitutive activity of the orphan 7TM receptor EBI2: analysis of receptor activation in the absence of an agonist. Mol. Pharmacol. 74: 1008-21 [PMID:18628402]

50. Benned-Jensen T and Rosenkilde MM. (2010) Distinct expression and ligand-binding profiles of two constitutively active GPR17 splice variants. Br. J. Pharmacol. 159: 1092-105 [PMID:20148890]

51. Bhatnagar S, Mishra S and Pathak R. (2011) Mining human genome for novel purinergic P2Y receptors: a sequence analysis and molecular modeling approach. J. Recept. Signal Transduct. Res. 31: 75-84 [PMID:21142848]

52. Bhattacharyya S, Luan J, Challis B, Keogh J, Montague C, Brennand J, Morten J, Lowenbeim S, Jenkins S, Farooqi IS, Wareham NJ and O'Rahilly S. (2006) Sequence variants in the melatonin-related receptor gene (GPR50) associate with circulating triglyceride and HDL levels. J. Lipid Res. 47: 761-6 [PMID:16436372]

53. Bi Y, Dzierba CD, Fink C, Garcia Y, Green M, Han J, Kwon S, Kumi G, Liang Z and Liu Yet al.. (2015)

The discovery of potent agonists for GPR88, an orphan GPCR, for the potential treatment of CNS 
disorders. Bioorg. Med. Chem. Lett. 25: 1443-7 [PMID:25754495]

54. Bikkavilli RK, Tsang SY, Tang WM, Sun JX, Ngai SM, Lee SS, Ko WH, Wise H and Cheung WT. (2006) Identification and characterization of surrogate peptide ligand for orphan $G$ protein-coupled receptor mas using phage-displayed peptide library. Biochem. Pharmacol. 71: 319-37 [PMID:16336942]

55. Birkenbach M, Josefsen K, Yalamanchili R, Lenoir G and Kieff E. (1993) Epstein-Barr virus-induced genes: first lymphocyte-specific G protein-coupled peptide receptors. J. Virol. 67: 2209-20 [PMID:8383238]

56. Bjursell M, Gerdin AK, Jönsson M, Surve VV, Svensson L, Huang XF, Törnell J and Bohlooly-Y M. (2006) G protein-coupled receptor 12 deficiency results in dyslipidemia and obesity in mice. Biochem. Biophys. Res. Commun. 348: 359-66 [PMID:16887097]

57. Blaak H, Boers PH, Gruters RA, Schuitemaker H, van der Ende ME and Osterhaus AD. (2005) CCR5, GPR15, and CXCR6 are major coreceptors of human immunodeficiency virus type 2 variants isolated from individuals with and without plasma viremia. J. Virol. 79: 1686-700 [PMID:15650194]

58. Bly M. (2005) Examination of the trace amine-associated receptor 2 (TAAR2).Schizophr. Res. 80: 367-8 [PMID:15993565]

59. Bläsius R, Weber RG, Lichter P and Ogilvie A. (1998) A novel orphan G protein-coupled receptor primarily expressed in the brain is localized on human chromosomal band 2q21. J. Neurochem. 70: 1357-65 [PMID:9523551]

60. Boda E, Viganò F, Rosa P, Fumagalli M, Labat-Gest V, Tempia F, Abbracchio MP, Dimou L and Buffo A. (2011) The GPR17 receptor in NG2 expressing cells: Focus on in vivocell maturation and participation in acute trauma and chronic damage. Glia 59: 1958-73 [PMID:21956849]

61. Bodenmüller $\mathrm{H}$ and Schaller HC. (1981) Conserved amino acid sequence of a neuropeptide, the head activator, from coelenterates to humans. Nature 293: 579-80 [PMID:7290191]

62. Boehm M, Hepworth D, Loria PM, Norquay LD, Filipski KJ, Chin JE, Cameron KO, Brenner M, Bonnette P and Cabral S et al.. (2013) Chemical Probe Identification Platform for Orphan GPCRs Using Focused Compound Screening: GPR39 as a Case Example. ACS Med Chem Lett 4: 1079-84 [PMID:24900608]

63. Bogdanov YD, Dale L, King BF, Whittock N and Burnstock G. (1997) Early expression of a novel nucleotide receptor in the neural plate of Xenopus embryos. J. Biol. Chem. 272: 12583-90 [PMID:9139711]

64. Bohnekamp J, Böselt I, Saalbach A, Tönjes A, Kovacs P, Biebermann H, Manvelyan HM, Polte T, Gasperikova D, Lkhagvasuren S, Baier L, Stumvoll M, Römpler H and Schöneberg T. (2010) Involvement of the chemokine-like receptor GPR33 in innate immunity. Biochem. Biophys. Res. Commun. 396: 272-7 [PMID:20399748]

65. Bolick DT, Skaflen MD, Johnson LE, Kwon SC, Howatt D, Daugherty A, Ravichandran KS and Hedrick CC. (2009) G2A deficiency in mice promotes macrophage activation and atherosclerosis. Circ. Res. 104: 318-27 [PMID:19106413]

66. Bolick DT, Whetzel AM, Skaflen M, Deem TL, Lee J and Hedrick CC. (2007) Absence of the G proteincoupled receptor G2A in mice promotes monocyte/endothelial interactions in aorta. Circ. Res. 100: 572-80 [PMID:17255525]

67. Bonini and James A. et al.. (2002) Methods of identifying compounds that bind to SNORF25 receptors. Patent number: US6468756.

68. Booden MA, Siderovski DP and Der CJ. (2002) Leukemia-associated Rho guanine nucleotide exchange factor promotes $\mathrm{G}$ alpha q-coupled activation of RhoA. Mol. Cell. Biol. 22: 4053-61 [PMID:12024019]

69. Borowsky B, Adham N, Jones KA, Raddatz R, Artymyshyn R, Ogozalek KL, Durkin MM, Lakhlani PP, Bonini JA and Pathirana $S$ et al.. (2001) Trace amines: identification of a family of mammalian G proteincoupled receptors. Proc. Natl. Acad. Sci. U.S.A. 98: 8966-71 [PMID:11459929]

70. Borrelli F and Izzo AA. (2009) Role of acylethanolamides in the gastrointestinal tract with special reference to food intake and energy balance. Best Pract. Res. Clin. Endocrinol. Metab. 23: 33-49 [PMID:19285259]

71. Botelho-Santos GA, Bader M, Alenina N and Santos RA. (2012) Altered regional blood flow distribution in Mas-deficient mice. Ther Adv Cardiovasc Dis 6: 201-11 [PMID:23045193]

72. Bouchard C, Pagé J, Bédard A, Tremblay P and Vallières L. (2007) G protein-coupled receptor 84, a microglia-associated protein expressed in neuroinflammatory conditions. Glia 55: 790-800 [PMID:17390309]

73. Boulay JL, Ionescu MC, Sivasankaran B, Labuhn M, Dolder-Schlienger B, Taylor E, Morin P, Hemmings BA, Lino MM, Jones G, Maier D and Merlo A. (2009) The 10q25.3-26.1 G protein-coupled receptor gene GPR26 is epigenetically silenced in human gliomas. Int. J. Oncol. 35: 1123-31 [PMID:19787267]

74. Boyle RG, Humphries J, Mitchell T, Showell GA, Apaya R, lijima H, Shimada H, Arai T, Ueno H and Usui Y et al.. (2005) The design of a new potent and selective ligand for the orphan bombesin receptor subtype 3 (BRS3). J. Pept. Sci. 11: 136-41 [PMID:15635635]

75. Bradshaw HB, Lee SH and McHugh D. (2009) Orphan endogenous lipids and orphan GPCRs: a good 
match. Prostaglandins Other Lipid Mediat. 89: 131-4 [PMID:19379823]

76. Breen C, Brownjohn PW and Ashton JC. (2012) The atypical cannabinoid O-1602 increases hind paw sensitisation in the chronic constriction injury model of neuropathic pain. Neurosci. Lett. 508: 119-22 [PMID:22227298]

77. Brennan and Thomas et al.. (2007) Transgenic mice containing GPCR5-1 gene disruptions. Patent number: US2007/0074299.

78. Bresnick JN, Skynner HA, Chapman KL, Jack AD, Zamiara E, Negulescu P, Beaumont K, Patel S and McAllister G. (2003) Identification of signal transduction pathways used by orphan g protein-coupled receptors. Assay Drug Dev Technol 1: 239-49 [PMID:15090189]

79. Brown AJ. (2007) Novel cannabinoid receptors. Br. J. Pharmacol. 152: 567-75 [PMID:17906678]

80. Brown AJ, Daniels DA, Kassim M, Brown S, Haslam CP, Terrell VR, Brown J, Nichols PL, Staton PC and Wise A et al.. (2011) Pharmacology of GPR55 in yeast and identification of GSK494581A as a mixedactivity glycine transporter subtype 1 inhibitor and GPR55 agonist. J. Pharmacol. Exp. Ther. 337: 236-46 [PMID:21233197]

81. Brown AJ, Goldsworthy SM, Barnes AA, Eilert MM, Tcheang L, Daniels D, Muir AI, Wigglesworth MJ, Kinghorn I and Fraser NJ et al.. (2003) The Orphan G protein-coupled receptors GPR41 and GPR43 are activated by propionate and other short chain carboxylic acids. J. Biol. Chem. 278: 11312-9 [PMID:12496283]

82. Brown AJ, Jupe $S$ and Briscoe CP. (2005) A family of fatty acid binding receptors.DNA Cell Biol. 24: 5461 [PMID:15684720]

83. Brown AJ and Robin Hiley C. (2009) Is GPR55 an anandamide receptor? Vitam. Horm. 81: 111-37 [PMID:19647110]

84. Brown DG, Sanderson MR, Garman E and Neidle S. (1992) Crystal structure of a berenil$\mathrm{d}(\mathrm{CGCAAATTTGCG})$ complex. An example of drug-DNA recognition based on sequence-dependent structural features. J. Mol. Biol. 226: 481-90 [PMID:1640462]

85. Brézillon S, Detheux M, Parmentier M, Hökfelt T and Hurd YL. (2001) Distribution of an orphan G-protein coupled receptor (JP05) mRNA in the human brain. Brain Res. 921: 21-30 [PMID:11720708]

86. Buccioni M, Marucci G, Dal Ben D, Giacobbe D, Lambertucci C, Soverchia L, Thomas A, Volpini R and Cristalli G. (2011) Innovative functional cAMP assay for studying G protein-coupled receptors: application to the pharmacological characterization of GPR17. Purinergic Signal. 7: 463-8 [PMID:21773766]

87. Bunnemann B, Fuxe K, Metzger R, Mullins J, Jackson TR, Hanley MR and Ganten D. (1990) Autoradiographic localization of mas proto-oncogene mRNA in adult rat brain using in situ hybridization. Neurosci. Lett. 114: 147-53 [PMID:2203997]

88. Burns JM, Summers BC, Wang Y, Melikian A, Berahovich R, Miao Z, Penfold ME, Sunshine MJ, Littman DR, Kuo CJ, Wei K, McMaster BE, Wright K, Howard MC and Schall TJ. (2006) A novel chemokine receptor for SDF-1 and I-TAC involved in cell survival, cell adhesion, and tumor development. J. Exp. Med. 203: 2201-13 [PMID:16940167]

89. Burstein ES, Ott TR, Feddock M, Ma JN, Fuhs S, Wong S, Schiffer HH, Brann MR and Nash NR. (2006) Characterization of the Mas-related gene family: structural and functional conservation of human and rhesus MrgX receptors. Br. J. Pharmacol.147: 73-82 [PMID:16284629]

90. Burstein SH, McQuain CA, Ross AH, Salmonsen RA and Zurier RE. (2011) Resolution of inflammation by $\mathrm{N}$-arachidonoylglycine. J. Cell. Biochem. 112: 3227-33 [PMID:21732409]

91. Bäck M, Powell WS, Dahlén SE, Drazen JM, Evans JF, Serhan CN, Shimizu T, Yokomizo T and Rovati GE. (2014) Update on leukotriene, lipoxin and oxoeicosanoid receptors: IUPHAR Review 7. Br. J. Pharmacol. 171: 3551-74 [PMID:24588652]

92. Bédard $A$, Tremblay $P$, Chernomoretz $A$ and Vallières L. (2007) Identification of genes preferentially expressed by microglia and upregulated during cuprizone-induced inflammation. Glia 55: 777-89 [PMID:17285589]

93. Cahir-McFarland ED, Carter K, Rosenwald A, Giltnane JM, Henrickson SE, Staudt LM and Kieff E. (2004) Role of NF-kappa B in cell survival and transcription of latent membrane protein 1-expressing or EpsteinBarr virus latency III-infected cells. J. Virol. 78: 4108-19 [PMID:15047827]

94. Cai H, Yang H, Xiang B, Li S, Liu S, Wan L, Zhang J, Li Y, Cheng J and Lu X. (2010) Selective apoptotic killing of solid and hematologic tumor cells by bombesin-targeted delivery of mitochondria-disrupting peptides. Mol. Pharm. 7: 586-96 [PMID:20141196]

95. Cai LY, Abe M, Izumi S, Imura M, Yasugi T and Ushijima T. (2007) Identification of PRTFDC1 silencing and aberrant promoter methylation of GPR150, ITGA8 and HOXD11 in ovarian cancers. Life Sci. 80: 145865 [PMID:17303177]

96. Canals M, Jenkins L, Kellett E and Milligan G. (2006) Up-regulation of the angiotensin II type 1 receptor by 
the MAS proto-oncogene is due to constitutive activation of Gq/G11 by MAS. J. Biol. Chem. 281: 16757-67 [PMID:16611642]

97. Cantagrel V, Lossi AM, Boulanger S, Depetris D, Mattei MG, Gecz J, Schwartz CE, Van Maldergem L and Villard L. (2004) Disruption of a new X linked gene highly expressed in brain in a family with two mentally retarded males. J. Med. Genet. 41: 736-42 [PMID:15466006]

98. Cantarella G, Scollo M, Lempereur L, Saccani-Jotti G, Basile F and Bernardini R. (2011) Endocannabinoids inhibit release of nerve growth factor by inflammation-activated mast cells. Biochem. Pharmacol. 82: 380-8 [PMID:21601562]

99. Carmon KS, Gong X, Lin Q, Thomas A and Liu Q. (2011) R-spondins function as ligands of the orphan receptors LGR4 and LGR5 to regulate Wnt/beta-catenin signaling. Proc. Natl. Acad. Sci. U.S.A. 108: 11452-7 [PMID:21693646]

100. Carter AN, Cole CL, Playle AG, Ramsay EJ and Shervington AA. (2008) GPR26: a marker for primary glioblastoma? Mol. Cell. Probes 22: 133-7 [PMID:18037267]

101. Cartoni C, Yasumatsu K, Ohkuri T, Shigemura N, Yoshida R, Godinot N, le Coutre J, Ninomiya Y and Damak S. (2010) Taste preference for fatty acids is mediated by GPR40 and GPR120. J. Neurosci. 30: 8376-82 [PMID:20573884]

102. Castellone RD, Leffler NR, Dong L and Yang LV. (2011) Inhibition of tumor cell migration and metastasis by the proton-sensing GPR4 receptor. Cancer Lett. 312: 197-208 [PMID:21917373]

103. Castro CH, Santos RA, Ferreira AJ, Bader M, Alenina N and Almeida AP. (2006) Effects of genetic deletion of angiotensin-(1-7) receptor Mas on cardiac function during ischemia/reperfusion in the isolated perfused mouse heart. Life Sci. 80: 264-8 [PMID:17055538]

104. Castro CH, Santos RA, Ferreira AJ, Bader M, Alenina N and Almeida AP. (2005) Evidence for a functional interaction of the angiotensin-(1-7) receptor Mas with AT1 and AT2 receptors in the mouse heart. Hypertension 46: 937-42 [PMID:16157793]

105. Catalán V, Gómez-Ambrosi J, Rotellar F, Silva C, Gil MJ, Rodríguez A, Cienfuegos JA, Salvador J and Frühbeck G. (2007) The obestatin receptor (GPR39) is expressed in human adipose tissue and is downregulated in obesity-associated type 2 diabetes mellitus. Clin. Endocrinol. (Oxf) 66: 598-601 [PMID:17371481]

106. Cavanaugh DJ, Lee H, Lo L, Shields SD, Zylka MJ, Basbaum Al and Anderson DJ. (2009) Distinct subsets of unmyelinated primary sensory fibers mediate behavioral responses to noxious thermal and mechanical stimuli. Proc. Natl. Acad. Sci. U.S.A. 106: 9075-80 [PMID:19451647]

107. Cebra-Thomas JA, Tsai JY, Pilder SH, Copeland NG, Jenkins NA and Silver LM. (1992) Localization of the Mas proto-oncogene to a densely marked region of mouse chromosome 17 associated with genomic imprinting. Genomics 13: 444-6 [PMID:1612602]

108. Ceruti S, Viganò F, Boda E, Ferrario S, Magni G, Boccazzi M, Rosa P, Buffo A and Abbracchio MP. (2011) Expression of the new P2Y-like receptor GPR17 during oligodendrocyte precursor cell maturation regulates sensitivity to ATP-induced death. Glia 59: 363-78 [PMID:21264945]

109. Ceruti S, Villa G, Genovese T, Mazzon E, Longhi R, Rosa P, Bramanti P, Cuzzocrea S and Abbracchio MP. (2009) The P2Y-like receptor GPR17 as a sensor of damage and a new potential target in spinal cord injury. Brain 132: 2206-18 [PMID:19528093]

110. Chan SY, Speck RF, Power C, Gaffen SL, Chesebro B and Goldsmith MA. (1999) V3 recombinants indicate a central role for CCR 5 as a coreceptor in tissue infection by human immunodeficiency virus type 1. J. Virol. 73: 2350-8 [PMID:9971818]

111. Chartrel N, Alvear-Perez R, Leprince J, Iturrioz X, Reaux-Le Goazigo A, Audinot V, Chomarat $P$, Coge $F$, Nosjean O, Rodriguez M, Galizzi JP, Boutin JA, Vaudry H and Llorens-Cortes C. (2007) Comment on "Obestatin, a peptide encoded by the ghrelin gene, opposes ghrelin's effects on food intake". Science 315: 766; author reply 766 [PMID:17289961]

112. Chaste P, Clement N, Mercati O, Guillaume JL, Delorme R, Botros HG, Pagan C, Périvier S, Scheid I, Nygren G, Anckarsäter H, Rastam M, Ståhlberg O, Gillberg C, Serrano E, Lemière N, Launay JM, MourenSimeoni MC, Leboyer M, Gillberg C, Jockers R and Bourgeron T. (2010) Identification of pathway-biased and deleterious melatonin receptor mutants in autism spectrum disorders and in the general population. PLOS ONE 5: e11495 [PMID:20657642]

113. Chen A, Dong L, Leffler NR, Asch AS, Witte ON and Yang LV. (2011) Activation of GPR4 by acidosis increases endothelial cell adhesion through the cAMP/Epac pathway. PLOS ONE 6: e27586 [PMID:22110680]

114. Chen CL, Broom DC, Liu Y, de Nooij JC, Li Z, Cen C, Samad OA, Jessell TM, Woolf CJ and Ma Q. (2006) Runx1 determines nociceptive sensory neuron phenotype and is required for thermal and neuropathic pain. Neuron 49: 365-77 [PMID:16446141] 
115. Chen $\mathrm{H}$ and Ikeda SR. (2004) Modulation of ion channels and synaptic transmission by a human sensory neuron-specific G-protein-coupled receptor, SNSR4/mrgX1, heterologously expressed in cultured rat neurons. J. Neurosci. 24: 5044-53 [PMID:15163697]

116. Chen IM, Harvey RC, Mullighan CG, Gastier-Foster J, Wharton W, Kang H, Borowitz MJ, Camitta BM, Carroll AJ and Devidas M et al.. (2012) Outcome modeling with CRLF2, IKZF1, JAK, and minimal residual disease in pediatric acute lymphoblastic leukemia: a Children's Oncology Group study. Blood 119: 3512-22 [PMID:22368272]

117. Chen PH, Chen X, Lin Z, Fang D and He X. (2013) The structural basis of R-spondin recognition by LGR5 and RNF43. Genes Dev. 27: 1345-50 [PMID:23756651]

118. Chen Q, Kogan JH, Gross AK, Zhou Y, Walton NM, Shin R, Heusner CL, Miyake S, Tajinda K and Tamura $\mathrm{K}$ et al.. (2012) SREB2/GPR85, a schizophrenia risk factor, negatively regulates hippocampal adult neurogenesis and neurogenesis-dependent learning and memory. Eur. J. Neurosci. 36: 2597-608 [PMID:22697179]

119. Chen Y, Wu H, Wang S, Koito H, Li J, Ye F, Hoang J, Escobar SS, Gow A, Arnett HA, Trapp BD, Karandikar NJ, Hsieh J and Lu QR. (2009) The oligodendrocyte-specific G protein-coupled receptor GPR17 is a cell-intrinsic timer of myelination. Nat. Neurosci. 12: 1398-406 [PMID:19838178]

120. Chiang N, Fredman G, Bäckhed F, Oh SF, Vickery T, Schmidt BA and Serhan CN. (2012) Infection regulates pro-resolving mediators that lower antibiotic requirements. Nature 484: 524-8 [PMID:22538616]

121. Chiba T, Ueno S, Obara Y and Nakahata N. (2011) A synthetic cannabinoid, CP55940, inhibits lipopolysaccharide-induced cytokine mRNA expression in a cannabinoid receptor-independent mechanism in rat cerebellar granule cells. J. Pharm. Pharmacol. 63: 636-47 [PMID:21492165]

122. Chiellini G, Erba P, Carnicelli V, Manfredi C, Frascarelli S, Ghelardoni S, Mariani G and Zucchi R. (2012) Distribution of exogenous [125I]-3-iodothyronamine in mouse in vivo: relationship with trace amineassociated receptors. J. Endocrinol. 213: 223-30 [PMID:22442117]

123. Chobanian HR, Guo Y, Liu P, Chioda M, Lanza Jr TJ, Chang L, Kelly TM, Kan Y, Palyha O and Guan XM et al.. (2012) Discovery of MK-7725, A Potent, Selective Bombesin Receptor Subtype-3 Agonist for the Treatment of Obesity. ACS Med Chem Lett 3: 252-6 [PMID:24900461]

124. Choi JW, Lee SY and Choi Y. (1996) Identification of a putative G protein-coupled receptor induced during activation-induced apoptosis of T cells. Cell. Immunol. 168: 78-84 [PMID:8599842]

125. Chu X, Shen M, Xie F, Miao XJ, Shou WH, Liu L, Yang PP, Bai YN, Zhang KY and Yang let al.. (2013) An X chromosome-wide association analysis identifies variants in GPR174 as a risk factor for Graves' disease. J. Med. Genet. 50: 479-85 [PMID:23667180]

126. Chu ZL, Carroll C, Alfonso J, Gutierrez V, He H, Lucman A, Pedraza M, Mondala H, Gao H and Bagnol D et al.. (2008) A role for intestinal endocrine cell-expressed g protein-coupled receptor 119 in glycemic control by enhancing glucagon-like Peptide-1 and glucose-dependent insulinotropic Peptide release. Endocrinology 149: 2038-47 [PMID:18202141]

127. Chu ZL, Carroll C, Chen R, Alfonso J, Gutierrez V, He H, Lucman A, Xing C, Sebring K and Zhou «t al.. (2010) N-oleoyldopamine enhances glucose homeostasis through the activation of GPR119. Mol. Endocrinol. 24: 161-70 [PMID:19901198]

128. Chu ZL, Jones RM, He H, Carroll C, Gutierrez V, Lucman A, Moloney M, Gao H, Mondala H and Bagnol D et al.. (2007) A role for beta-cell-expressed $G$ protein-coupled receptor 119 in glycemic control by enhancing glucose-dependent insulin release. Endocrinology 148: 2601-9 [PMID:17289847]

129. Chung JJ, Okamoto Y, Coblitz B, Li M, Qiu Y and Shikano S. (2009) PI3K/Akt signalling-mediated protein surface expression sensed by 14-3-3 interacting motif. FEBS J. 276: 5547-58 [PMID:19691494]

130. Ciana P, Fumagalli M, Trincavelli ML, Verderio C, Rosa P, Lecca D, Ferrario S, Parravicini C, Capra V, Gelosa P, Guerrini U, Belcredito S, Cimino M, Sironi L, Tremoli E, Rovati GE, Martini C and Abbracchio MP. (2006) The orphan receptor GPR17 identified as a new dual uracil nucleotides/cysteinyl-leukotrienes receptor. EMBO J. 25: 4615-27 [PMID:16990797]

131. Cikos S, Gregor P and Koppel J. (2001) Cloning of a novel biogenic amine receptor-like G protein-coupled receptor expressed in human brain. Biochim. Biophys. Acta 1521: 66-72 [PMID:11690637]

132. Cilliers T, Nhlapo J, Coetzer M, Orlovic D, Ketas T, Olson WC, Moore JP, Trkola A and Morris L. (2003) The CCR5 and CXCR4 coreceptors are both used by human immunodeficiency virus type 1 primary isolates from subtype C. J. Virol. 77: 4449-56 [PMID:12634405]

133. Cilliers T, Willey S, Sullivan WM, Patience T, Pugach P, Coetzer M, Papathanasopoulos M, Moore JP, Trkola A and Clapham P et al.. (2005) Use of alternate coreceptors on primary cells by two HIV-1 isolates. Virology 339: 136-44 [PMID:15992849]

134. Clark HF, Gurney AL, Abaya E, Baker K, Baldwin D, Brush J, Chen J, Chow B, Chui C and Crowley Cet al.. (2003) The secreted protein discovery initiative (SPDI), a large-scale effort to identify novel human 
secreted and transmembrane proteins: a bioinformatics assessment. Genome Res. 13: 2265-70 [PMID:12975309]

135. Clayton F, Kotler DP, Kuwada SK, Morgan T, Stepan C, Kuang J, Le J and Fantini J. (2001) Gp120induced Bob/GPR15 activation: a possible cause of human immunodeficiency virus enteropathy. Am. J. Pathol. 159: 1933-9 [PMID:11696454]

136. Codina J, Opyd TS, Powell ZB, Furdui CM, Petrovic S, Penn RB and DuBose TD. (2011) pH-dependent regulation of the $\alpha$-subunit of $\mathrm{H}_{+-\mathrm{K}+-\mathrm{ATPase}}(\mathrm{HKa2}$ ). Am. J. Physiol. Renal Physiol.301: F536-43 [PMID:21653633]

137. Coetzer M, Nedellec R, Cilliers T, Meyers T, Morris L and Mosier DE. (2011) Extreme genetic divergence is required for coreceptor switching in HIV-1 subtype C. J. Acquir. Immune Defic. Syndr.56: 9-15 [PMID:20921899]

138. Console-Bram L, Brailoiu E, Brailoiu GC, Sharir H and Abood ME. (2014) Activation of GPR18 by cannabinoid compounds: a tale of biased agonism. Br. J. Pharmacol. 171: 3908-17 [PMID:24762058]

139. Cox HM, Tough IR, Woolston AM, Zhang L, Nguyen AD, Sainsbury A and Herzog H. (2010) Peptide YY is critical for acylethanolamine receptor Gpr119-induced activation of gastrointestinal mucosal responses. Cell Metab. 11: 532-42 [PMID:20519124]

140. Cox PJ, Pitcher T, Trim SA, Bell CH, Qin W and Kinloch RA. (2008) The effect of deletion of the orphan G - protein coupled receptor (GPCR) gene MrgE on pain-like behaviours in mice. Mol Pain 4: 2 [PMID:18197975]

141. Croitoru-Lamoury J, Guillemin GJ, Boussin FD, Mognetti B, Gigout LI, Chéret A, Vaslin B, Le Grand R, Brew BJ and Dormont D. (2003) Expression of chemokines and their receptors in human and simian astrocytes: evidence for a central role of TNF alpha and IFN gamma in CXCR4 and CCR5 modulation. Glia 41: 354-70 [PMID:12555203]

142. Crouch E, Persson A, Chang D and Parghi D. (1991) Surfactant protein D. Increased accumulation in silica-induced pulmonary lipoproteinosis. Am. J. Pathol. 139: 765-76 [PMID:1656758]

143. Crozier RA, Ajit SK, Kaftan EJ and Pausch MH. (2007) MrgD activation inhibits KCNQ/M-currents and contributes to enhanced neuronal excitability. J. Neurosci. 27: 4492-6 [PMID:17442834]

144. da Costa Gonçalves AC, Leite R, Fraga-Silva RA, Pinheiro SV, Reis AB, Reis FM, Touyz RM, Webb RC, Alenina $\mathrm{N}$ and Bader $\mathrm{M}$ et al.. (2007) Evidence that the vasodilator angiotensin-(1-7)-Mas axis plays an important role in erectile function. Am. J. Physiol. Heart Circ. Physiol.293: H2588-96 [PMID:17616753]

145. da Silveira KD, Coelho FM, Vieira AT, Sachs D, Barroso LC, Costa VV, Bretas TL, Bader M, de Sousa LP and da Silva TA et al.. (2010) Anti-inflammatory effects of the activation of the angiotensin-(1-7) receptor, MAS, in experimental models of arthritis. J. Immunol. 185: 5569-76 [PMID:20935211]

146. Daly CJ, Ross RA, Whyte J, Henstridge CM, Irving AJ and McGrath JC. (2010) Fluorescent ligand binding reveals heterogeneous distribution of adrenoceptors and 'cannabinoid-like' receptors in small arteries. $B r$. J. Pharmacol. 159: 787-96 [PMID:20136833]

147. Damond F, Benard A, Ruelle J, Alabi A, Kupfer B, Gomes P, Rodes B, Albert J, Böni J and Garson £t al.. (2008) Quality control assessment of human immunodeficiency virus type 2 (HIV-2) viral load quantification assays: results from an international collaboration on HIV-2 infection in 2006. J. Clin. Microbiol. 46: 208891 [PMID:18434556]

148. Daniele S, Lecca D, Trincavelli ML, Ciampi O, Abbracchio MP and Martini C. (2010) Regulation of PC12 cell survival and differentiation by the new P2Y-like receptor GPR17. Cell. Signal. 22: 697-706 [PMID:20056144]

149. Daniele S, Trincavelli ML, Gabelloni P, Lecca D, Rosa P, Abbracchio MP and Martini C. (2011) Agonistinduced desensitization/resensitization of human $G$ protein-coupled receptor 17: a functional cross-talk between purinergic and cysteinyl-leukotriene ligands. J. Pharmacol. Exp. Ther. 338: 559-67 [PMID:21531793]

150. Davenport AP, Alexander SP, Sharman JL, Pawson AJ, Benson HE, Monaghan AE, Liew WC, Mpamhanga CP, Bonner TI and Neubig RR et al.. (2013) International Union of Basic and Clinical Pharmacology. LXXXVIII. G protein-coupled receptor list: recommendations for new pairings with cognate ligands. Pharmacol. Rev. 65: 967-86 [PMID:23686350]

151. Davenport AP, Bonner TI, Foord SM, Harmar AJ, Neubig RR, Pin JP, Spedding M, Kojima M and Kangawa K. (2005) International Union of Pharmacology. LVI. Ghrelin receptor nomenclature, distribution, and function. Pharmacol. Rev. 57: 541-6 [PMID:16382107]

152. de Lau W, Barker N, Low TY, Koo BK, Li VS, Teunissen H, Kujala P, Haegebarth A, Peters PJ and van de Wetering $M$ et al.. (2011) Lgr5 homologues associate with Wnt receptors and mediate R-spondin signalling. Nature 476: 293-7 [PMID:21727895]

153. De Moerlooze L, Williamson J, Liners F, Perret J and Parmentier M. (2000) Cloning and chromosomal 
mapping of the mouse and human genes encoding the orphan glucocorticoid-induced receptor (GPR83). Cytogenet. Cell Genet. 90: 146-50 [PMID:11060465]

154. Deng HK, Unutmaz D, KewalRamani VN and Littman DR. (1997) Expression cloning of new receptors used by simian and human immunodeficiency viruses. Nature 388: 296-300 [PMID:9230441]

155. Derwińska K, Bernaciak J, Wiśniowiecka-Kowalnik B, Obersztyn E, Bocian E and Stankiewicz P. (2009) Autistic features with speech delay in a girl with an approximately $1.5-\mathrm{Mb}$ deletion in $6 \mathrm{q} 16.1$, including GPR63 and FUT9. Clin. Genet. 75: 199-202 [PMID:18717687]

156. Dharmadhikari AV, Kang SH, Szafranski P, Person RE, Sampath S, Prakash SK, Bader PI, Phillips JA, Hannig V and Williams M et al.. (2012) Small rare recurrent deletions and reciprocal duplications in 2q21.1, including brain-specific ARHGEF4 and GPR148. Hum. Mol. Genet. 21: 3345-55 [PMID:22543972]

157. Dijkman R, van Doorn R, Szuhai K, Willemze R, Vermeer MH and Tensen CP. (2007) Gene-expression profiling and array-based CGH classify CD4+CD56+ hematodermic neoplasm and cutaneous myelomonocytic leukemia as distinct disease entities. Blood 109: 1720-7 [PMID:17068154]

158. DiLuigi A, Weitzman VN, Pace MC, Siano LJ, Maier D and Mehlmann LM. (2008) Meiotic arrest in human oocytes is maintained by a Gs signaling pathway. Biol. Reprod. 78: 667-72 [PMID:18184921]

159. Dinter J, Mühlhaus J, Wienchol CL, Yi CX, Nürnberg D, Morin S, Grüters A, Köhrle J, Schöneberg T and Tschöp M et al.. (2015) Inverse agonistic action of 3-iodothyronamine at the human trace amineassociated receptor 5. PLOS ONE 10: e0117774 [PMID:25706283]

160. Divorty N, Mackenzie AE, Nicklin SA and Milligan G. (2015) G protein-coupled receptor 35: an emerging target in inflammatory and cardiovascular disease. Front Pharmaco/6: 41 [PMID:25805994]

161. Dong L, Li Z, Leffler NR, Asch AS, Chi JT and Yang LV. (2013) Acidosis activation of the proton-sensing GPR4 receptor stimulates vascular endothelial cell inflammatory responses revealed by transcriptome analysis. PLOS ONE 8: e61991 [PMID:23613998]

162. Dong X, Han S, Zylka MJ, Simon MI and Anderson DJ. (2001) A diverse family of GPCRs expressed in specific subsets of nociceptive sensory neurons. Cell 106: 619-32 [PMID:11551509]

163. Duan J, Martinez M, Sanders AR, Hou C, Saitou N, Kitano T, Mowry BJ, Crowe RR, Silverman JM and Levinson DF et al.. (2004) Polymorphisms in the trace amine receptor 4 (TRAR4) gene on chromosome 6q23.2 are associated with susceptibility to schizophrenia. Am. J. Hum. Genet.75: 624-38 [PMID:15329799]

164. Duan S, Du J, Xu Y, Xing Q, Wang H, Wu S, Chen Q, Li X, Li X and Shen £t al.. (2006) Failure to find association between TRAR4 and schizophrenia in the Chinese Han population. J Neural Transm 113: 3815 [PMID:16075187]

165. Dubins JS, Sanchez-Alavez M, Zhukov V, Sanchez-Gonzalez A, Moroncini G, Carvajal-Gonzalez S, Hadcock JR, Bartfai T and Conti B. (2012) Downregulation of GPR83 in the hypothalamic preoptic area reduces core body temperature and elevates circulating levels of adiponectin. Metab. Clin. Exp. 61: 148693 [PMID:22560055]

166. Duong CQ, Bared SM, Abu-Khader A, Buechler C, Schmitz A and Schmitz G. (2004) Expression of the lysophospholipid receptor family and investigation of lysophospholipid-mediated responses in human macrophages. Biochim. Biophys. Acta 1682: 112-9 [PMID:15158762]

167. Dussor G, Zylka MJ, Anderson DJ and McCleskey EW. (2008) Cutaneous sensory neurons expressing the Mrgprd receptor sense extracellular ATP and are putative nociceptors. J. Neurophysiol. 99: 1581-9 [PMID:18234974]

168. Eberini I, Daniele S, Parravicini C, Sensi C, Trincavelli ML, Martini C and Abbracchio MP. (2011) In silico identification of new ligands for GPR17: a promising therapeutic target for neurodegenerative diseases. J. Comput. Aided Mol. Des. 25: 743-52 [PMID:21744154]

169. Eberwine $J$ and Bartfai T. (2011) Single cell transcriptomics of hypothalamic warm sensitive neurons that control core body temperature and fever response Signaling asymmetry and an extension of chemical neuroanatomy. Pharmacol. Ther. 129: 241-59 [PMID:20970451]

170. Edinger AL, Hoffman TL, Sharron M, Lee B, O'Dowd B and Doms RW. (1998) Use of GPR1, GPR15, and STRL33 as coreceptors by diverse human immunodeficiency virus type 1 and simian immunodeficiency virus envelope proteins. Virology 249: 367-78 [PMID:9791028]

171. Edinger AL, Mankowski JL, Doranz BJ, Margulies BJ, Lee B, Rucker J, Sharron M, Hoffman TL, Berson JF, Zink MC, Hirsch VM, Clements JE and Doms RW. (1997) CD4-independent, CCR5-dependent infection of brain capillary endothelial cells by a neurovirulent simian immunodeficiency virus strain. Proc. Natl. Acad. Sci. U.S.A. 94: 14742-7 [PMID:9405683]

172. Edson MA, Lin YN and Matzuk MM. (2010) Deletion of the novel oocyte-enriched gene, Gpr149, leads to increased fertility in mice. Endocrinology 151: 358-68 [PMID:19887567]

173. Egerod KL, Holst B, Petersen PS, Hansen JB, Mulder J, Hökfelt T and Schwartz TW. (2007) GPR39 splice 
variants versus antisense gene LYPD1: expression and regulation in gastrointestinal tract, endocrine pancreas, liver, and white adipose tissue. Mol. Endocrinol. 21: 1685-98 [PMID:17488974]

174. Eggerickx D, Denef JF, Labbe O, Hayashi Y, Refetoff S, Vassart G, Parmentier M and Libert F. (1995) Molecular cloning of an orphan G-protein-coupled receptor that constitutively activates adenylate cyclase. Biochem. J. 309 ( Pt 3): 837-43 [PMID:7639700]

175. El-Hashim AZ, Renno WM, Raghupathy R, Abduo HT, Akhtar S and Benter IF. (2012) Angiotensin-(1-7) inhibits allergic inflammation, via the MAS1 receptor, through suppression of ERK1/2- and NF-KBdependent pathways. Br. J. Pharmacol. 166: 1964-76 [PMID:22339213]

176. Elbim C, Monceaux V, Mueller YM, Lewis MG, François S, Diop O, Akarid K, Hurtrel B, Gougerot-Pocidalo MA and Lévy $Y$ et al.. (2008) Early divergence in neutrophil apoptosis between pathogenic and nonpathogenic simian immunodeficiency virus infections of nonhuman primates. J. Immunol. 181: 8613-23 [PMID:19050281]

177. Ellinghaus D, Folseraas T, Holm K, Ellinghaus E, Melum E, Balschun T, Laerdahl JK, Shiryaev A, Gotthardt DN and Weismüller TJ et al.. (2013) Genome-wide association analysis in primary sclerosing cholangitis and ulcerative colitis identifies risk loci at GPR35 and TCF4. Hepatology 58: 1074-83 [PMID:22821403]

178. Engel KM, Schröck K, Teupser D, Holdt LM, Tönjes A, Kern M, Dietrich K, Kovacs P, Krügel U and Scheidt HA et al.. (2011) Reduced food intake and body weight in mice deficient for the G protein-coupled receptor GPR82. PLoS ONE 6: e29400 [PMID:22216272]

179. Engelstoft MS, Egerod KL, Holst B and Schwartz TW. (2008) A gut feeling for obesity: 7TM sensors on enteroendocrine cells. Cell Metab. 8: 447-9 [PMID:19041758]

180. Engemaier E, Römpler H, Schöneberg T and Schulz A. (2006) Genomic and supragenomic structure of the nucleotide-like G-protein-coupled receptor GPR34. Genomics 87: 254-64 [PMID:16338117]

181. Ensor HM, Schwab C, Russell LJ, Richards SM, Morrison H, Masic D, Jones L, Kinsey SE, Vora AJ and Mitchell CD et al.. (2011) Demographic, clinical, and outcome features of children with acute lymphoblastic leukemia and CRLF2 deregulation: results from the MRC ALL97 clinical trial. Blood 117: 2129-36 [PMID:21106984]

182. Ernst C, Sequeira A, Klempan T, Ernst N, Ffrench-Mullen J and Turecki G. (2007) Confirmation of regionspecific patterns of gene expression in the human brain. Neurogenetics 8: 219-24 [PMID:17375343]

183. Esteban V, Heringer-Walther S, Sterner-Kock A, de Bruin R, van den Engel S, Wang Y, Mezzano S, Egido J, Schultheiss HP and Ruiz-Ortega M et al.. (2009) Angiotensin-(1-7) and the g protein-coupled receptor MAS are key players in renal inflammation. PLoS ONE 4: e5406 [PMID:19404405]

184. Evangelou E, Valdes AM, Kerkhof HJ, Styrkarsdottir U, Zhu Y, Meulenbelt I, Lories RJ, Karassa FB, Tylzanowski P and Bos SD et al.. (2011) Meta-analysis of genome-wide association studies confirms a susceptibility locus for knee osteoarthritis on chromosome 7q22. Ann. Rheum. Dis. 70: 349-55 [PMID:21068099]

185. Fallarini S, Magliulo L, Paoletti T, de Lalla C and Lombardi G. (2010) Expression of functional GPR35 in human iNKT cells. Biochem. Biophys. Res. Commun. 398: 420-5 [PMID:20599711]

186. Farzan M, Choe H, Martin K, Marcon L, Hofmann W, Karlsson G, Sun Y, Barrett P, Marchand N, Sullivan N, Gerard N, Gerard C and Sodroski J. (1997) Two orphan seven-transmembrane segment receptors which are expressed in CD4-positive cells support simian immunodeficiency virus infection. J. Exp. Med. 186: 405-11 [PMID:9236192]

187. Fathi Z, Corjay MH, Shapira H, Wada E, Benya R, Jensen R, Viallet J, Sausville EA and Battey JF. (1993) BRS-3: a novel bombesin receptor subtype selectively expressed in testis and lung carcinoma cells. J. Biol. Chem. 268: 5979-84 [PMID:8383682]

188. Feng Y, Guan XM, Li J, Metzger JM, Zhu Y, Juhl K, Zhang BB, Thornberry NA, Reitman ML and Zhou YP. (2011) Bombesin receptor subtype-3 (BRS-3) regulates glucose-stimulated insulin secretion in pancreatic islets across multiple species. Endocrinology 152: 4106-15 [PMID:21878513]

189. Feng Y, Wigg K, King N, Vetró A, Kiss E, Kapornai K, Mayer L, Gádoros J, Kennedy JL, Kovacs M, Barr $\mathrm{CL}$ and International Consortium for Childhood-Onset Mood Disorders. (2007) GPR50 is not associated with childhood-onset mood disorders in a large sample of Hungarian families. Psychiatr. Genet. 17: 347-50 [PMID:18075476]

190. Fischer A, Zundler S, Atreya R, Rath T, Voskens C, Hirschmann S, López-Posadas R, Watson A, Becker $C$ and Schuler $G$ et al.. (2016) Differential effects of $\alpha 4 \beta 7$ and GPR15 on homing of effector and regulatory T cells from patients with UC to the inflamed gut in vivo. Gut 65: 1642-64 [PMID:26209553]

191. Fleischer J, Schwarzenbacher K and Breer H. (2007) Expression of trace amine-associated receptors in the Grueneberg ganglion. Chem. Senses 32: 623-31 [PMID:17556730]

192. Fleissner D, Frede A, Knott M, Knuschke T, Geffers R, Hansen W, Dobos G, Langhorst J, Buer J and 
Westendorf AM. (2011) Generation and function of immunosuppressive human and murine CD8+ T cells by transforming growth factor- $\beta$ and retinoic acid. Immunology 134: 82-92 [PMID:21711349]

193. Fonseca BM, Teixeira NA, Almada M, Taylor AH, Konje JC and Correia-da-Silva G. (2011) Modulation of the novel cannabinoid receptor - GPR55 - during rat fetoplacental development. Placenta 32: 462-9 [PMID:21497900]

194. Foord SM, Bonner TI, Neubig RR, Rosser EM, Pin JP, Davenport AP, Spedding M and Harmar AJ. (2005) International Union of Pharmacology. XLVI. G protein-coupled receptor list. Pharmacol. Rev. 57: 279-88 [PMID:15914470]

195. Ford LA, Roelofs AJ, Anavi-Goffer S, Mowat L, Simpson DG, Irving AJ, Rogers MJ, Rajnicek AM and Ross RA. (2010) A role for L-alpha-lysophosphatidylinositol and GPR55 in the modulation of migration, orientation and polarization of human breast cancer cells. Br. J. Pharmacol. 160: 762-71 [PMID:20590578]

196. Fournier D, Luft FC, Bader M, Ganten D and Andrade-Navarro MA. (2012) Emergence and evolution of the renin-angiotensin-aldosterone system. J. Mol. Med. 90: 495-508 [PMID:22527880]

197. Fraga-Silva RA, Pinheiro SV, Gonçalves AC, Alenina N, Bader M and Santos RA. (2008) The antithrombotic effect of angiotensin-(1-7) involves mas-mediated NO release from platelets. Mol. Med. 14: 28-35 [PMID:18026570]

198. Frasch SC, Berry KZ, Fernandez-Boyanapalli R, Jin HS, Leslie C, Henson PM, Murphy RC and Bratton DL. (2008) NADPH oxidase-dependent generation of lysophosphatidylserine enhances clearance of activated and dying neutrophils via G2A. J. Biol. Chem. 283: 33736-49 [PMID:18824544]

199. Frasch SC, Zemski-Berry K, Murphy RC, Borregaard N, Henson PM and Bratton DL. (2007) Lysophospholipids of different classes mobilize neutrophil secretory vesicles and induce redundant signaling through G2A. J. Immunol. 178: 6540-8 [PMID:17475884]

200. Fredriksson R, Höglund PJ, Gloriam DE, Lagerström MC and Schiöth HB. (2003) Seven evolutionarily conserved human rhodopsin G protein-coupled receptors lacking close relatives. FEBS Lett. 554: 381-8 [PMID:14623098]

201. Frick KK and Bushinsky DA. (2010) Effect of metabolic and respiratory acidosis on intracellular calcium in osteoblasts. Am. J. Physiol. Renal Physiol. 299: F418-25 [PMID:20504884]

202. Frick KK, Krieger NS, Nehrke K and Bushinsky DA. (2009) Metabolic acidosis increases intracellular calcium in bone cells through activation of the proton receptor OGR1. J. Bone Miner. Res. 24: 305-13 [PMID:18847331]

203. Friedman RC, Farh KK, Burge CB and Bartel DP. (2009) Most mammalian mRNAs are conserved targets of microRNAs. Genome Res. 19: 92-105 [PMID:18955434]

204. Fujii H, Kawai K, Kawamura K, Mizusuna A, Onoda Y, Murachi M, Tanaka T, Endoh T and Nagase H. (2001) Synthesis of optically active TAN-67, a highly selective delta opioid receptor agonist, and investigation of its pharmacological properties. Drug Des Discov 17: 325-30 [PMID:11765135]

205. Fujisawa D, Kashiwakura J, Kita H, Kikukawa Y, Fujitani Y, Sasaki-Sakamoto T, Kuroda K, Nunomura S, Hayama $\mathrm{K}$ and Terui T et al.. (2014) Expression of Mas-related gene X2 on mast cells is upregulated in the skin of patients with severe chronic urticaria. J. Allergy Clin. Immunol. 134: 622-633.e9 [PMID:24954276]

206. Fujiwara S, Yamashita Y, Choi YL, Watanabe H, Kurashina K, Soda M, Enomoto M, Hatanaka H, Takada S, Ozawa K and Mano H. (2007) Transforming activity of purinergic receptor P2Y, G protein coupled, 8 revealed by retroviral expression screening. Leuk. Lymphoma 48: 978-86 [PMID:17487742]

207. Fukuda $\mathrm{H}$, Ito $\mathrm{S}$, Watari $\mathrm{K}$, Mogi $\mathrm{C}$, Arisawa M, Okajima F, Kurose $\mathrm{H}$ and Shuto S. (2016) Identification of a Potent and Selective GPR4 Antagonist as a Drug Lead for the Treatment of Myocardial Infarction. ACS Med Chem Lett 7: 493-7 [PMID:27190599]

208. Fukunaga S, Setoguchi S, Hirasawa A and Tsujimoto G. (2006) Monitoring ligand-mediated internalization of $G$ protein-coupled receptor as a novel pharmacological approach. Life Sci. 80: 17-23 [PMID:16978657]

209. Fumagalli M, Daniele S, Lecca D, Lee PR, Parravicini C, Fields RD, Rosa P, Antonucci F, Verderio C and Trincavelli ML et al.. (2011) Phenotypic changes, signaling pathway, and functional correlates of GPR17expressing neural precursor cells during oligodendrocyte differentiation. J. Biol. Chem. 286: 10593-604 [PMID:21209081]

210. Furutani N, Hondo M, Tsujino N and Sakurai T. (2010) Activation of bombesin receptor subtype-3 influences activity of orexin neurons by both direct and indirect pathways. J. Mol. Neurosci. 42: 106-11 [PMID:20467915]

211. Gagnon L, Leduc M, Thibodeau JF, Zhang MZ, Grouix B, Sarra-Bournet F, Gagnon W, Hince K, Tremblay $M$ and Geerts $L$ et al.. (2018) A Newly Discovered Antifibrotic Pathway Regulated by Two Fatty Acid Receptors: GPR40 and GPR84. Am. J. Pathol. 188: 1132-1148 [PMID:29454750]

212. Gantz I, Muraoka A, Yang YK, Samuelson LC, Zimmerman EM, Cook H and Yamada T. (1997) Cloning and chromosomal localization of a gene (GPR18) encoding a novel seven transmembrane receptor highly 
expressed in spleen and testis. Genomics 42: 462-6 [PMID:9205118]

213. Gao J, Tian L, Weng G, Bhagroo NV, Sorenson RL, O'Brien TD, Luo J and Guo Z. (2011) Stimulating beta cell replication and improving islet graft function by GPR119 agonists. Transpl. Int. 24: 1124-34 [PMID:21902730]

214. Gao J, Tian L, Weng G, O'Brien TD, Luo J and Guo Z. (2011) Stimulating $\beta$-cell replication and improving islet graft function by AR231453, A gpr119 agonist. Transplant. Proc. 43: 3217-20 [PMID:22099761]

215. Gao Y, Kitagawa K, Hiramatsu Y, Kikuchi H, Isobe T, Shimada M, Uchida C, Hattori T, Oda T and Nakayama K et al.. (2006) Up-regulation of GPR48 induced by down-regulation of p27Kip1 enhances carcinoma cell invasiveness and metastasis. Cancer Res. 66: 11623-31 [PMID:17178856]

216. Gao Y, Shan ZY, Wang H, Zhang HM and Teng WP. (2009) Inhibitory effect of shRNA targeting GPR48 on invasion and metastasis of human cervical carcinoma cell line HeLa. Ai Zheng 28: 104-7 [PMID:19550120]

217. Gardner J, Wu S, Ling L, Danao J, Li Y, Yeh WC, Tian H and Baribault H. (2012) G-protein-coupled receptor GPR21 knockout mice display improved glucose tolerance and increased insulin response. Biochem. Biophys. Res. Commun. 418: 1-5 [PMID:22155242]

218. Gatto D, Paus D, Basten A, Mackay CR and Brink R. (2009) Guidance of B cells by the orphan G proteincoupled receptor EBI2 shapes humoral immune responses. Immunity 31: 259-69 [PMID:19615922]

219. Gatto D, Wood K and Brink R. (2011) EBI2 operates independently of but in cooperation with CXCR5 and CCR7 to direct B cell migration and organization in follicles and the germinal center. J. Immunol. 187: 4621-8 [PMID:21948984]

220. Gava E, de Castro CH, Ferreira AJ, Colleta H, Melo MB, Alenina N, Bader M, Oliveira LA, Santos RA and Kitten GT. (2012) Angiotensin-(1-7) receptor Mas is an essential modulator of extracellular matrix protein expression in the heart. Regul. Pept. 175: 30-42 [PMID:22285513]

221. Gembardt F, Grajewski S, Vahl M, Schultheiss HP and Walther T. (2008) Angiotensin metabolites can stimulate receptors of the Mas-related genes family. Mol. Cell. Biochem. 319: 115-23 [PMID:18636314]

222. Geng Y, Xiong D, Mosyak L, Malito DL, Kniazeff J, Chen Y, Burmakina S, Quick M, Bush M and Javitch JA et al.. (2012) Structure and functional interaction of the extracellular domain of human GABA(B) receptor GBR2. Nat. Neurosci. 15: 970-8 [PMID:22660477]

223. Gerhard DS, Wagner L, Feingold EA, Shenmen CM, Grouse LH, Schuler G, Klein SL, Old S, Rasooly R and Good P et al.. (2004) The status, quality, and expansion of the NIH full-length cDNA project: the Mammalian Gene Collection (MGC). Genome Res. 14: 2121-7 [PMID:15489334]

224. Gerwins P, Nordstedt $C$ and Fredholm BB. (1990) Characterization of adenosine A1 receptors in intact DDT1 MF-2 smooth muscle cells. Mol. Pharmacol. 38: 660-6 [PMID:2172773]

225. Gharu L, Ringe R and Bhattacharya J. (2012) Evidence of extended alternate coreceptor usage by HIV-1 clade $C$ envelope obtained from an Indian patient. Virus Res. 163: 410-4 [PMID:22086059]

226. Ghate A, Befort K, Becker JA, Filliol D, Bole-Feysot C, Demebele D, Jost B, Koch M and Kieffer BL. (2007) Identification of novel striatal genes by expression profiling in adult mouse brain. Neuroscience 146: 118292 [PMID:17395390]

227. Gironacci MM, Adamo HP, Corradi G, Santos RA, Ortiz P and Carretero OA. (2011) Angiotensin (1-7) induces MAS receptor internalization. Hypertension 58: 176-81 [PMID:21670420]

228. Glatt S, Halbauer D, Heindl S, Wernitznig A, Kozina D, Su KC, Puri C, Garin-Chesa P and Sommergruber W. (2008) hGPR87 contributes to viability of human tumor cells. Int. J. Cancer 122: 2008-16 [PMID:18183596]

229. Glinka A, Dolde C, Kirsch N, Huang YL, Kazanskaya O, Ingelfinger D, Boutros M, Cruciat CM and Niehrs C. (2011) LGR4 and LGR5 are R-spondin receptors mediating Wnt/ß-catenin and Wnt/PCP signalling. EMBO Rep. 12: 1055-61 [PMID:21909076]

230. Gloriam DE, Fredriksson R and Schiöth HB. (2007) The G protein-coupled receptor subset of the rat genome. BMC Genomics 8: 338 [PMID:17892602]

231. Gloriam DE, Schiöth HB and Fredriksson R. (2005) Nine new human Rhodopsin family G-protein coupled receptors: identification, sequence characterisation and evolutionary relationship. Biochim. Biophys. Acta 1722: 235-46 [PMID:15777626]

232. Godlewski G, Offertáler L, Wagner JA and Kunos G. (2009) Receptors for acylethanolamides-GPR55 and GPR119. Prostaglandins Other Lipid Mediat. 89: 105-11 [PMID:19615459]

233. Gomes I, Aryal DK, Wardman JH, Gupta A, Gagnidze K, Rodriguiz RM, Kumar S, Wetsel WC, Pintar JE and Fricker LD et al.. (2013) GPR171 is a hypothalamic G protein-coupled receptor for BigLEN, a neuropeptide involved in feeding. Proc. Natl. Acad. Sci. U.S.A. 110: 16211-6 [PMID:24043826]

234. Gomes I, Bobeck EN, Margolis EB, Gupta A, Sierra S, Fakira AK, Fujita W, Müller TD, Müller A and Tschöp MH et al.. (2016) Identification of GPR83 as the receptor for the neuroendocrine peptide PEN.Sci 
Signal 9: ra43 [PMID:27117253]

235. Gong X, Carmon KS, Lin Q, Thomas A, Yi J and Liu Q. (2012) LGR6 is a high affinity receptor of Rspondins and potentially functions as a tumor suppressor. PLoS ONE 7: e37137 [PMID:22615920]

236. Gonzalez N, Hocart SJ, Portal-Nuñez S, Mantey SA, Nakagawa T, Zudaire E, Coy DH and Jensen RT. (2008) Molecular basis for agonist selectivity and activation of the orphan bombesin receptor subtype 3 receptor. J. Pharmacol. Exp. Ther. 324: 463-74 [PMID:18006692]

237. González N, Mantey SA, Pradhan TK, Sancho V, Moody TW, Coy DH and Jensen RT.. (2009) Characterization of putative GRP- and NMB-receptor antagonist's interaction with human receptors. Peptides 30: 1473-86 [PMID:19463875]

238. Gorbulev V, Akhundova A, Grzeschik KH and Fahrenholz F. (1994) Organization and chromosomal localization of the gene for the human bombesin receptor subtype expressed in pregnant uterus. FEBS Lett. 340: 260-4 [PMID:8131855]

239. Grosse J, Tarnow P, Römpler H, Schneider B, Sedlmeier R, Huffstadt U, Korthaus D, Nehls M, Wattler S, Schöneberg T, Biebermann H and Augustin M. (2006) N-ethyl-N-nitrosourea-based generation of mouse models for mutant G protein-coupled receptors. Physiol. Genomics 26: 209-17 [PMID:16720677]

240. Grünewald E, Kinnell HL, Porteous DJ and Thomson PA. (2009) GPR50 interacts with neuronal NOGO-A and affects neurite outgrowth. Mol. Cell. Neurosci. 42: 363-71 [PMID:19699797]

241. Guan XM, Chen H, Dobbelaar PH, Dong Y, Fong TM, Gagen K, Gorski J, He S, Howard AD and Jian 飞t al. (2010) Regulation of energy homeostasis by bombesin receptor subtype-3: selective receptor agonists for the treatment of obesity. Cell Metabolism 11: 101-112 [PMID:20096642]

242. Guan XM, Metzger JM, Yang L, Raustad KA, Wang SP, Spann SK, Kosinski JA, Yu H, Shearman LP and Faidley TD et al. (2010) Antiobesity effect of MK-5046, a novel bombesin receptor subtype-3 agonist. Journal of Pharmacology and Expimental Therapeutics336: 356-364 [PMID:21036912]

243. Gubitz AK and Reppert SM. (1999) Assignment of the melatonin-related receptor to human chromosome $X$ (GPR50) and mouse chromosome X (Gpr50). Genomics 55: 248-51 [PMID:9933574]

244. Gugger M, White R, Song S, Waser B, Cescato R, Rivière P and Reubi JC. (2008) GPR87 is an overexpressed G-protein coupled receptor in squamous cell carcinoma of the lung. Dis. Markers 24: 41-50 [PMID:18057535]

245. Guimarães GG, Santos SH, Oliveira ML, Pimenta-Velloso EP, Motta DF, Martins AS, Alenina N, Bader M, Santos RA and Campagnole-Santos MJ. (2012) Exercise induces renin-angiotensin system unbalance and high collagen expression in the heart of Mas-deficient mice. Peptides 38: 54-61 [PMID:22921883]

246. Guo Y, Zhang W, Giroux C, Cai Y, Ekambaram P, Dilly AK, Hsu A, Zhou S, Maddipati KR and Liu «t al.. (2011) Identification of the orphan G protein-coupled receptor GPR31 as a receptor for 12-(S)hydroxyeicosatetraenoic acid. J. Biol. Chem. 286: 33832-40 [PMID:21712392]

247. Habtezion A, Nguyen LP, Hadeiba H and Butcher EC. (2016) Leukocyte Trafficking to the Small Intestine and Colon. Gastroenterology 150: 340-54 [PMID:26551552]

248. Hamouda HO, Chen P, Levoye A, Sözer-Topçular N, Daulat AM, Guillaume JL, Ravid R, Savaskan E, Ferry G, Boutin JA, Delagrange P, Jockers R and Maurice P. (2007) Detection of the human GPR50 orphan seven transmembrane protein by polyclonal antibodies mapping different epitopes. J. Pineal Res. 43: 10-5 [PMID:17614830]

249. Han S, Narayanan S, Kim SH, Calderon I, Zhu X, Kawasaki A, Yue D, Lehmann J, Wong A and Buzard DJ et al.. (2015) Discovery of a novel trans-1,4-dioxycyclohexane GPR119 agonist series.Bioorg. Med. Chem. Lett. 25: 3034-8 [PMID:26048791]

250. Han SK, Dong X, Hwang JI, Zylka MJ, Anderson DJ and Simon MI. (2002) Orphan G protein-coupled receptors MrgA1 and MrgC11 are distinctively activated by RF-amide-related peptides through the Galpha q/11 pathway. Proc. Natl. Acad. Sci. U.S.A. 99: 14740-5 [PMID:12397184]

251. Han T, Lee BM, Park YH, Lee DH, Choi HH, Lee T and Kim H. (2018) YH18968, a Novel 1,2,4-Triazolone G-Protein Coupled Receptor 119 Agonist for the Treatment of Type 2 Diabetes Mellitus. Biomol Ther (Seoul) 26: 201-209 [PMID:29495245]

252. Hannedouche S, Zhang J, Yi T, Shen W, Nguyen D, Pereira JP, Guerini D, Baumgarten BU, Roggo S and Wen B et al.. (2011) Oxysterols direct immune cell migration via EBI2. Nature 475: 524-7 [PMID:21796212]

253. Hansen HS and Diep TA. (2009) N-acylethanolamines, anandamide and food intake.Biochem. Pharmacol. 78: 553-60 [PMID:19413995]

254. Hansen HS, Rosenkilde MM, Holst JJ and Schwartz TW. (2012) GPR119 as a fat sensor.Trends Pharmacol. Sci. 33: 374-81 [PMID:22560300]

255. Hansen KB, Rosenkilde MM, Knop FK, Wellner N, Diep TA, Rehfeld JF, Andersen UB, Holst JJ and Hansen HS. (2011) 2-Oleoyl glycerol is a GPR119 agonist and signals GLP-1 release in humans. J. Clin. Endocrinol. Metab. 96: E1409-17 [PMID:21778222] 
256. Hansen W, Loser K, Westendorf AM, Bruder D, Pfoertner S, Siewert C, Huehn J, Beissert S and Buer J. (2006) G protein-coupled receptor 83 overexpression in naive CD4+CD25- T cells leads to the induction of Foxp3+ regulatory T cells in vivo. J. Immunol. 177: 209-15 [PMID:16785516]

257. Hansen W, Westendorf AM, Toepfer T, Mauel S, Geffers R, Gruber AD and Buer J. (2010) Inflammation in vivo is modulated by GPR83 isoform-4 but not GPR83 isoform-1 expression in regulatory T cells. Genes Immun. 11: 357-61 [PMID:20200545]

258. Harden TK. (2013) Enigmatic GPCR finds a stimulating drug.Sci Signa/6: pe34 [PMID:24150253]

259. Harrigan MT, Campbell NF and Bourgeois S. (1991) Identification of a gene induced by glucocorticoids in murine T-cells: a potential G protein-coupled receptor. Mol. Endocrinol. 5: 1331-8 [PMID:1663214]

260. Harrison JK, Barber CM and Lynch KR. (1993) Molecular cloning of a novel rat G-protein-coupled receptor gene expressed prominently in lung, adrenal, and liver. FEBS Lett. 318: 17-22 [PMID:8382168]

261. Harvey RC, Mullighan CG, Chen IM, Wharton W, Mikhail FM, Carroll AJ, Kang H, Liu W, Dobbin KK, Smith MA, Carroll WL, Devidas M, Bowman WP, Camitta BM, Reaman GH, Hunger SP, Downing JR and Willman CL. (2010) Rearrangement of CRLF2 is associated with mutation of JAK kinases, alteration of IKZF1, Hispanic/Latino ethnicity, and a poor outcome in pediatric B-progenitor acute lymphoblastic leukemia. Blood 115: 5312-21 [PMID:20139093]

262. Hase M, Yokomizo T, Shimizu T and Nakamura M. (2008) Characterization of an orphan G proteincoupled receptor, GPR20, that constitutively activates Gi proteins. J. Biol. Chem. 283: 12747-55 [PMID:18347022]

263. Hasegawa H, Lei J, Matsumoto T, Onishi S, Suemori K and Yasukawa M. (2011) Lysophosphatidylcholine enhances the suppressive function of human naturally occurring regulatory T cells through TGF- $\beta$ production. Biochem. Biophys. Res. Commun. 415: 526-31 [PMID:22074829]

264. Hata S, Emi Y, lyanagi T and Osumi T. (1995) cDNA cloning of a putative G protein-coupled receptor from brain. Biochim. Biophys. Acta 1261: 121-5 [PMID:7893747]

265. Hattori T, Obinata H, Ogawa A, Kishi M, Tatei K, Ishikawa O and Izumi T. (2008) G2A plays proinflammatory roles in human keratinocytes under oxidative stress as a receptor for 9hydroxyoctadecadienoic acid. J. Invest. Dermatol. 128: 1123-33 [PMID:18034171]

266. Hay DL, Walker CS and Poyner DR. (2011) Adrenomedullin and calcitonin gene-related peptide receptors in endocrine-related cancers: opportunities and challenges. Endocr. Relat. Cancer 18: C1-14 [PMID:21051558]

267. He S, Dobbelaar PH, Liu J, Jian T, Sebhat IK, Lin LS, Goodman A, Guo C, Guzzo PR and Hadden Net al.. (2010) Discovery of substituted biphenyl imidazoles as potent, bioavailable bombesin receptor subtype-3 agonists. Bioorg. Med. Chem. Lett. 20: 1913-7 [PMID:20167483]

268. He W, Miao FJ, Lin DC, Schwandner RT, Wang Z, Gao J, Chen JL, Tian H and Ling L. (2004) Citric acid cycle intermediates as ligands for orphan G-protein-coupled receptors. Nature 429: 188-93 [PMID:15141213]

269. Heiber M, Docherty JM, Shah G, Nguyen T, Cheng R, Heng HH, Marchese A, Tsui LC, Shi X and George $\mathrm{SR}$ et al.. (1995) Isolation of three novel human genes encoding $\mathrm{G}$ protein-coupled receptors.DNA Cell Biol. 14: 25-35 [PMID:7832990]

270. Heiber M, Marchese A, Nguyen T, Heng HH, George SR and O'Dowd BF. (1996) A novel human gene encoding a G-protein-coupled receptor (GPR15) is located on chromosome 3. Genomics 32: 462-5 [PMID:8838812]

271. Heinig M, Petretto E, Wallace C, Bottolo L, Rotival M, Lu H, Li Y, Sarwar R, Langley SR, Bauerfeind A, Hummel O, Lee YA, Paskas S, Rintisch C, Saar K, Cooper J, Buchan R, Gray EE, Cyster JG, Cardiogenics Consortium, Erdmann J, Hengstenberg C, Maouche S, Ouwehand WH, Rice CM, Samani NJ, Schunkert H, Goodall AH, Schulz H, Roider HG, Vingron M, Blankenberg S, Münzel T, Zeller T, Szymczak S, Ziegler A, Tiret L, Smyth DJ, Pravenec M, Aitman TJ, Cambien F, Clayton D, Todd JA, Hubner N and Cook SA. (2010) A trans-acting locus regulates an anti-viral expression network and type 1 diabetes risk. Nature 467: 460-4 [PMID:20827270]

272. Heise CE, O'Dowd BF, Figueroa DJ, Sawyer N, Nguyen T, Im DS, Stocco R, Bellefeuille JN, Abramovitz M and Cheng R et al.. (2000) Characterization of the human cysteinyl leukotriene 2 receptor.J. Biol. Chem. 275: 30531-6 [PMID:10851239]

273. Hellebrand S, Schaller HC and Wittenberger T. (2000) The brain-specific G-protein coupled receptor GPR85 with identical protein sequence in man and mouse maps to human chromosome 7q31. Biochim. Biophys. Acta 1493: 269-72 [PMID:10978537]

274. Hellebrand S, Wittenberger T, Schaller HC and Hermans-Borgmeyer I. (2001) Gpr85, a novel member of the G-protein coupled receptor family, prominently expressed in the developing mouse cerebral cortex. Brain Res. Gene Expr. Patterns 1: 13-6 [PMID:15018813] 
275. Hennen S, Wang H, Peters L, Merten N, Simon K, Spinrath A, Blättermann S, Akkari R, Schrage R and Schröder R et al.. (2013) Decoding signaling and function of the orphan $G$ protein-coupled receptor GPR17 with a small-molecule agonist. Sci Signa/6: ra93 [PMID:24150254]

276. Henstridge CM, Balenga NA, Ford LA, Ross RA, Waldhoer M and Irving AJ. (2009) The GPR55 ligand Lalpha-lysophosphatidylinositol promotes RhoA-dependent Ca2+ signaling and NFAT activation. FASEB J. 23: 183-93 [PMID:18757503]

277. Henstridge CM, Balenga NA, Kargl J, Andradas C, Brown AJ, Irving A, Sanchez C and Waldhoer M. (2011) Minireview: recent developments in the physiology and pathology of the lysophosphatidylinositolsensitive receptor GPR55. Mol. Endocrinol. 25: 1835-48 [PMID:21964594]

278. Henstridge CM, Balenga NA, Schröder R, Kargl JK, Platzer W, Martini L, Arthur S, Penman J, Whistler JL, Kostenis E, Waldhoer M and Irving AJ. (2010) GPR55 ligands promote receptor coupling to multiple signalling pathways. Br. J. Pharmacol. 160: 604-14 [PMID:20136841]

279. Heringer-Walther S, Gembardt F, Perschel FH, Katz N, Schultheiss HP and Walther T. (2012) The genetic deletion of Mas abolishes salt induced hypertension in mice. Eur. J. Pharmacol.689: 147-53 [PMID:22652430]

280. Hertzberg L, Vendramini E, Ganmore I, Cazzaniga G, Schmitz M, Chalker J, Shiloh R, lacobucci I, Shochat C, Zeligson S, Cario G, Stanulla M, Strehl S, Russell LJ, Harrison CJ, Bornhauser B, Yoda A, Rechavi G, Bercovich D, Borkhardt A, Kempski H, te Kronnie G, Bourquin JP, Domany E and Izraeli S. (2010) Down syndrome acute lymphoblastic leukemia, a highly heterogeneous disease in which aberrant expression of CRLF2 is associated with mutated JAK2: a report from the International BFM Study Group. Blood 115: 1006-17 [PMID:19965641]

281. Heynen-Genel S, Dahl R, Shi S, Milan L, Hariharan S, Sergienko E, Hedrick M, Dad S, Stonich D and Su Y et al.. (2010) Screening for Selective Ligands for GPR55 - AntagonistsProbe Reports from the NIH Molecular Libraries Program [PMID:22091481]

282. Hichami A, Datiche F, Ullah S, Liénard F, Chardigny JM, Cattarelli M and Khan NA. (2007) Olfactory discrimination ability and brain expression of c-fos, Gir and Glut 1 mRNA are altered in n-3 fatty aciddepleted rats. Behav. Brain Res. 184: 1-10 [PMID:17686536]

283. Hiley CR and Kaup SS. (2007) GPR55 and the vascular receptors for cannabinoids.Br. J. Pharmacol.152: 559-61 [PMID:17704825]

284. Hinckley M, Vaccari S, Horner K, Chen R and Conti M. (2005) The G-protein-coupled receptors GPR3 and GPR12 are involved in cAMP signaling and maintenance of meiotic arrest in rodent oocytes. Dev. Biol. 287: 249-61 [PMID:16229830]

285. Hirasawa A, Tsumaya K, Awaji T, Katsuma S, Adachi T, Yamada M, Sugimoto Y, Miyazaki S and Tsujimoto G. (2005) Free fatty acids regulate gut incretin glucagon-like peptide-1 secretion through GPR120. Nat Med 11: 90-94 [PMID:15619630]

286. Hirose K, Shimoda N and Kikuchi Y. (2011) Expression patterns of Igr4 and lgr6 during zebrafish development. Gene Expr. Patterns 11: 378-83 [PMID:21570488]

287. Ho WS. (2010) Angiogenesis: a new physiological role for N-arachidonoyl serine and GPR55?Br. J. Pharmacol. 160: 1580-2 [PMID:20649562]

288. Hoffmeister-Ullerich SA, Süsens U and Schaller HC. (2004) The orphan G-protein-coupled receptor GPR19 is expressed predominantly in neuronal cells during mouse embryogenesis. Cell Tissue Res. 318: 459-63 [PMID:15452705]

289. Holst B, Egerod KL, Jin C, Petersen PS, Østergaard MV, Hald J, Sprinkel AM, Størling J, MandrupPoulsen T, Holst JJ, Thams P, Orskov C, Wierup N, Sundler F, Madsen OD and Schwartz TW. (2009) G protein-coupled receptor 39 deficiency is associated with pancreatic islet dysfunction. Endocrinology 150: 2577-85 [PMID:19213833]

290. Holst B, Egerod KL, Schild E, Vickers SP, Cheetham S, Gerlach LO, Storjohann L, Stidsen CE, Jones R, Beck-Sickinger AG and Schwartz TW. (2007) GPR39 signaling is stimulated by zinc ions but not by obestatin. Endocrinology 148: 13-20 [PMID:16959833]

291. Holst B, Holliday ND, Bach A, Elling CE, Cox HM and Schwartz TW. (2004) Common structural basis for constitutive activity of the ghrelin receptor family. J. Biol. Chem. 279: 53806-17 [PMID:15383539]

292. Holst B, Nygaard R, Valentin-Hansen L, Bach A, Engelstoft MS, Petersen PS, Frimurer TM and Schwartz TW. (2010) A conserved aromatic lock for the tryptophan rotameric switch in TM-VI of seventransmembrane receptors. J. Biol. Chem. 285: 3973-85 [PMID:19920139]

293. Horikawa Y, Oda N, Cox NJ, Li X, Orho-Melander M, Hara M, Hinokio Y, Lindner TH, Mashima H and Schwarz PE et al.. (2000) Genetic variation in the gene encoding calpain-10 is associated with type 2 diabetes mellitus. Nat. Genet. 26: 163-75 [PMID:11017071]

294. Hsu SY, Kudo M, Chen T, Nakabayashi K, Bhalla A, van der Spek PJ, van Duin M and Hsueh AJ. (2000) 
The three subfamilies of leucine-rich repeat-containing G protein-coupled receptors (LGR): identification of LGR6 and LGR7 and the signaling mechanism for LGR7. Mol. Endocrinol. 14: 1257-71 [PMID:10935549]

295. Hsu SY, Liang SG and Hsueh AJ. (1998) Characterization of two LGR genes homologous to gonadotropin and thyrotropin receptors with extracellular leucine-rich repeats and a $G$ protein-coupled, seventransmembrane region. Mol. Endocrinol. 12: 1830-45 [PMID:9849958]

296. Hu G, Ren G and Shi Y. (2011) The putative cannabinoid receptor GPR55 promotes cancer cell proliferation. Oncogene 30: 139-41 [PMID:21057532]

297. Hu LA, Tang PM, Eslahi NK, Zhou T, Barbosa J and Liu Q. (2009) Identification of surrogate agonists and antagonists for orphan G-protein-coupled receptor GPR139. J Biomol Screen 14: 789-97 [PMID:19525486]

298. Huang CW, Tzeng JN, Chen YJ, Tsai WF, Chen CC and Sun WH. (2007) Nociceptors of dorsal root ganglion express proton-sensing G-protein-coupled receptors. Mol. Cell. Neurosci. 36: 195-210 [PMID:17720533]

299. Huang F, Mehta D, Predescu S, Kim KS and Lum H. (2007) A novel lysophospholipid- and pH-sensitive receptor, GPR4, in brain endothelial cells regulates monocyte transmigration. Endothelium 14: 25-34 [PMID:17364894]

300. Huang L, Ramirez JC, Frampton GA, Golden LE, Quinn MA, Pae HY, Horvat D, Liang LJ and DeMorrow S. (2011) Anandamide exerts its antiproliferative actions on cholangiocarcinoma by activation of the GPR55 receptor. Lab. Invest. 91: 1007-17 [PMID:21464819]

301. Huang Q, Feng D, Liu K, Wang P, Xiao H, Wang Y, Zhang S and Liu Z. (2014) A medium-chain fatty acid receptor Gpr84 in zebrafish: expression pattern and roles in immune regulation. Dev. Comp. Immunol. 45: 252-8 [PMID:24704214]

302. Huang WC, Swietach $P$, Vaughan-Jones RD, Ansorge $O$ and Glitsch MD. (2008) Extracellular acidification elicits spatially and temporally distinct Ca2+ signals. Curr. Biol. 18: 781-5 [PMID:18485712]

303. Huang XP, Karpiak J, Kroeze WK, Zhu H, Chen X, Moy SS, Saddoris KA, Nikolova VD, Farrell MS and Wang $S$ et al.. (2015) Allosteric ligands for the pharmacologically dark receptors GPR68 and GPR65. Nature 527: 477-83 [PMID:26550826]

304. Hughes TE. (2009) Emerging therapies for metabolic diseases--the focus is on diabetes and obesity.Curr Opin Chem Biol 13: 332-7 [PMID:19482541]

305. Hänze J, Dittrich K, Dötsch J and Rascher W. (1997) Molecular cloning of a novel human receptor gene with homology to the rat adrenomedullin receptor and high expression in heart and immune system. Biochem. Biophys. Res. Commun. 240: 183-8 [PMID:9367907]

306. Ichimonji I, Tomura H, Mogi C, Sato K, Aoki H, Hisada T, Dobashi K, Ishizuka T, Mori M and Okajima F. (2010) Extracellular acidification stimulates IL-6 production and $\mathrm{Ca}(2+)$ mobilization through protonsensing OGR1 receptors in human airway smooth muscle cells. Am. J. Physiol. Lung Cell Mol. Physiol. 299: L567-77 [PMID:20656891]

307. Ichimura A, Hirasawa A, Hara T and Tsujimoto G. (2009) Free fatty acid receptors act as nutrient sensors to regulate energy homeostasis. Prostaglandins Other Lipid Mediat. 89: 82-8 [PMID:19460454]

308. Ichimura A, Hirasawa A, Poulain-Godefroy O, Bonnefond A, Hara T, Yengo L, Kimura I, Leloire A, Liu N and lida K et al.. (2012) Dysfunction of lipid sensor GPR120 leads to obesity in both mouse and human. Nature 483: 350-4 [PMID:22343897]

309. Idris Al and Ralston SH. (2010) Cannabinoids and bone: friend or foe?Calcif. Tissue Int. 87: 285-97 [PMID:20532878]

310. Ignatov A, Hermans-Borgmeyer I and Schaller HC. (2004) Cloning and characterization of a novel Gprotein-coupled receptor with homology to galanin receptors. Neuropharmacology 46: 1114-20 [PMID:15111018]

311. Ignatov A, Lintzel J, Hermans-Borgmeyer I, Kreienkamp HJ, Joost $P$, Thomsen S, Methner A and Schaller HC. (2003) Role of the G-protein-coupled receptor GPR12 as high-affinity receptor for sphingosylphosphorylcholine and its expression and function in brain development. J. Neurosci. 23: 907-14 [PMID:12574419]

312. Ignatov A, Lintzel J, Kreienkamp HJ and Schaller HC. (2003) Sphingosine-1-phosphate is a high-affinity ligand for the G protein-coupled receptor GPR6 from mouse and induces intracellular $\mathrm{Ca} 2+$ release by activating the sphingosine-kinase pathway. Biochem. Biophys. Res. Commun. 311: 329-36 [PMID:14592418]

313. Ignatov A, Robert J, Gregory-Evans C and Schaller HC. (2006) RANTES stimulates Ca2+ mobilization and inositol trisphosphate (IP3) formation in cells transfected with G protein-coupled receptor 75 . Br. J. Pharmacol. 149: 490-7 [PMID:17001303]

314. Ikeno Y, Konno N, Cheon SH, Bolchi A, Ottonello S, Kitamoto K and Arioka M. (2005) Secretory phospholipases A2 induce neurite outgrowth in PC12 cells through lysophosphatidylcholine generation and 
activation of G2A receptor. J. Biol. Chem. 280: 28044-52 [PMID:15927955]

315. Ikubo M, Inoue A, Nakamura S, Jung S, Sayama M, Otani Y, Uwamizu A, Suzuki K, Kishi T and Shuto Aet al.. (2015) Structure-Activity Relationships of Lysophosphatidylserine Analogs as Agonists of G-ProteinCoupled Receptors GPR34, P2Y10, and GPR174. J. Med. Chem. 58: 4204-19 [PMID:25970039]

316. Im DS, Heise CE, Nguyen T, O'Dowd BF and Lynch KR. (2001) Identification of a molecular target of psychosine and its role in globoid cell formation. J. Cell Biol. 153: 429-34 [PMID:11309421]

317. Imai Y, Inoue H, Kataoka A, Hua-Qin W, Masuda M, Ikeda T, Tsukita K, Soda M, Kodama T, Fuwa T, Honda Y, Kaneko S, Matsumoto S, Wakamatsu K, Ito S, Miura M, Aosaki T, Itohara S and Takahashi R. (2007) Pael receptor is involved in dopamine metabolism in the nigrostriatal system. Neurosci. Res. 59: 413-25 [PMID:17889953]

318. Imai Y, Soda M, Inoue H, Hattori N, Mizuno Y and Takahashi R. (2001) An unfolded putative transmembrane polypeptide, which can lead to endoplasmic reticulum stress, is a substrate of Parkin. Cell 105: 891-902 [PMID:11439185]

319. Imamachi N, Park GH, Lee H, Anderson DJ, Simon MI, Basbaum Al and Han SK. (2009) TRPV1expressing primary afferents generate behavioral responses to pruritogens via multiple mechanisms. Proc. Natl. Acad. Sci. U.S.A. 106: 11330-5 [PMID:19564617]

320. Inoue A, Ishiguro J, Kitamura H, Arima N, Okutani M, Shuto A, Higashiyama S, Ohwada T, Arai $\mathrm{H}$ and Makide $\mathrm{K}$ et al.. (2012) TGFo shedding assay: an accurate and versatile method for detecting GPCR activation. Nat. Methods 9: 1021-9 [PMID:22983457]

321. Isaacman-Beck J, Hermann EA, Yi Y, Ratcliffe SJ, Mulenga J, Allen S, Hunter E, Derdeyn CA and Collman RG. (2009) Heterosexual transmission of human immunodeficiency virus type 1 subtype C: Macrophage tropism, alternative coreceptor use, and the molecular anatomy of CCR5 utilization. J. Virol. 83: 8208-20 [PMID:19515785]

322. Isberg V, Andersen KB, Bisig C, Dietz GP, Bräuner-Osborne H and Gloriam DE. (2014) Computer-aided discovery of aromatic I- $\alpha$-amino acids as agonists of the orphan $G$ protein-coupled receptor GPR139. $J$ Chem Inf Model 54: 1553-7 [PMID:24826842]

323. Ishida J, Hashimoto T, Hashimoto Y, Nishiwaki S, Iguchi T, Harada S, Sugaya T, Matsuzaki H, Yamamoto $\mathrm{R}$ and Shiota $\mathrm{N}$ et al.. (2004) Regulatory roles for APJ, a seven-transmembrane receptor related to angiotensin-type 1 receptor in blood pressure in vivo. J. Biol. Chem. 279: 26274-9 [PMID:15087458]

324. Ishiguro H, Onaivi ES, Horiuchi Y, Imai K, Komaki G, Ishikawa T, Suzuki M, Watanabe $Y$, Ando $T$ and Higuchi $S$ et al.. (2011) Functional polymorphism in the GPR55 gene is associated with anorexia nervosa. Synapse 65: 103-8 [PMID:20506567]

325. Ishii S, Kihara $Y$ and Shimizu T. (2005) Identification of T cell death-associated gene 8 (TDAG8) as a novel acid sensing G-protein-coupled receptor. J. Biol. Chem. 280: 9083-7 [PMID:15618224]

326. Ishizaka N, Okazaki H, Kurokawa K, Kumada M and Takuwa Y. (1994) Molecular cloning of a novel putative $\mathrm{G}$ protein-coupled receptor from rat aortic smooth muscle. Downregulation of the mRNA level by the cyclic AMP messenger pathway. Biochim. Biophys. Acta 1218: 173-80 [PMID:8018717]

327. Itagaki K, Barton BE, Murphy TF, Taheri S, Shu P, Huang H and Jordan ML. (2011) Eicosanoid-induced store-operated calcium entry in dendritic cells. J. Surg. Res. 169: 301-10 [PMID:20080257]

328. Ito J, Ito M, Nambu H, Fujikawa T, Tanaka K, Iwaasa H and Tokita S. (2009) Anatomical and histological profiling of orphan G-protein-coupled receptor expression in gastrointestinal tract of C57BL/6J mice. Cell Tissue Res. 338: 257-69 [PMID:19763624]

329. Ivanova EA, Bechtold DA, Dupré SM, Brennand J, Barrett P, Luckman SM and Loudon AS. (2008) Altered metabolism in the melatonin-related receptor (GPR50) knockout mouse. Am. J. Physiol. Endocrinol. Metab. 294: E176-82 [PMID:17957037]

330. Iwabuchi M, Ui-Tei K, Yamada K, Matsuda Y, Sakai Y, Tanaka K and Ohki-Hamazaki H. (2003) Molecular cloning and characterization of avian bombesin-like peptide receptors: new tools for investigating molecular basis for ligand selectivity. Br. J. Pharmacol. 139: 555-66 [PMID:12788815]

331. Iwashita M, Makide K, Nonomura T, Misumi Y, Otani Y, Ishida M, Taguchi R, Tsujimoto M, Aoki J and Arai $\mathrm{H}$ et al.. (2009) Synthesis and evaluation of lysophosphatidylserine analogues as inducers of mast cell degranulation. Potent activities of lysophosphatidylthreonine and its 2-deoxy derivative. J. Med. Chem. 52: 5837-63 [PMID:19743861]

332. Izzo AA and Sharkey KA. (2010) Cannabinoids and the gut: new developments and emerging concepts. Pharmacol. Ther. 126: 21-38 [PMID:20117132]

333. Jackson TR, Blair LA, Marshall J, Goedert M and Hanley MR. (1988) The mas oncogene encodes an angiotensin receptor. Nature 335: 437-40 [PMID:3419518]

334. Jacobi FK, Broghammer M, Pesch K, Zrenner E, Berger W, Meindl A and Pusch CM. (2000) Physical mapping and exclusion of GPR34 as the causative gene for congenital stationary night blindness type 1. 
Hum. Genet. 107: 89-91 [PMID:10982042]

335. Jacobs KA, Collins-Racie LA, Colbert M, Duckett M, Golden-Fleet M, Kelleher K, Kriz R, LaVallie ER, Merberg D and Spaulding V et al.. (1997) A genetic selection for isolating cDNAs encoding secreted proteins. Gene 198: 289-96 [PMID:9370294]

336. Jahnke GD, Miller MJ, Martínez A, Montuenga L and Cuttitta F. (1997) Adrenomedullin expression in the mouse mammary gland: evidence for the mature form in milk. J. Mol. Endocrinol. 19: 279-89 [PMID:9460649]

337. Jaks V, Barker N, Kasper M, van Es JH, Snippert HJ, Clevers H and Toftgård R. (2008) Lgr5 marks cycling, yet long-lived, hair follicle stem cells. Nat. Genet. 40: 1291-9 [PMID:18849992]

338. Jankowski V, Tölle M, Santos RA, Günthner T, Krause E, Beyermann M, Welker P, Bader M, Pinheiro SV and Sampaio WO et al.. (2011) Angioprotectin: an angiotensin II-like peptide causing vasodilatory effects. FASEB J. 25: 2987-95 [PMID:21628446]

339. Jenkins L, Brea J, Smith NJ, Hudson BD, Reilly G, Bryant NJ, Castro M, Loza MI and Milligan G. (2010) Identification of novel species-selective agonists of the G-protein-coupled receptor GPR35 that promote recruitment of $\beta$-arrestin-2 and activate Ga13. Biochem. J. 432: 451-9 [PMID:20919992]

340. Jennings CA, Harrison DC, Maycox PR, Crook B, Smart D and Hervieu GJ. (2003) The distribution of the orphan bombesin receptor subtype-3 in the rat CNS. Neuroscience 120: 309-24 [PMID:12890504]

341. Jensen T, Elster L, Nielsen SM, Poda SB, Loechel F, Volbracht C, Klewe IV, David L and Watson SP. (2014) The identification of GPR3 inverse agonist AF64394; the first small molecule inhibitor of GPR3 receptor function. Bioorg. Med. Chem. Lett. 24: 5195-8 [PMID:25442311]

342. Jeon J, Kim C, Sun W, Chung H, Park SH and Kim H. (2002) Cloning and localization of rgpr85 encoding rat G-protein-coupled receptor. Biochem. Biophys. Res. Commun. 298: 613-8 [PMID:12408996]

343. Jiang C, Parrish NF, Wilen CB, Li H, Chen Y, Pavlicek JW, Berg A, Lu X, Song H and Tilton JCet al.. (2011) Primary infection by a human immunodeficiency virus with atypical coreceptor tropism. J. Virol. 85: 10669-81 [PMID:21835785]

344. Jiménez N, Calvo A, Martínez A, Rosell D, Cuttitta F and Montuenga LM. (1999) Expression of adrenomedullin and proadrenomedullin $\mathrm{N}$-terminal 20 peptide in human and rat prostate. J. Histochem. Cytochem. 47: 1167-78 [PMID:10449538]

345. Jin C, Decker AM, Huang XP, Gilmour BP, Blough BE, Roth BL, Hu Y, Gill JB and Zhang XP. (2014) Synthesis, pharmacological characterization, and structure-activity relationship studies of small molecular agonists for the orphan GPR88 receptor. ACS Chem Neurosci 5: 576-87 [PMID:24793972]

346. Jin C, Decker AM, Makhijani VH, Besheer J, Darcq E, Kieffer BL and Maitra R. (2018) Discovery of a Potent, Selective, and Brain-Penetrant Small Molecule that Activates the Orphan Receptor GPR88 and Reduces Alcohol Intake. J. Med. Chem. 61: 6748-6758 [PMID:30011199]

347. Jin C, Yin F, Lin M, Li H, Wang Z, Weng J, Liu M, Da Dong X, Qu J and Tu L. (2008) GPR48 regulates epithelial cell proliferation and migration by activating EGFR during eyelid development. Invest. Ophthalmol. Vis. Sci. 49: 4245-53 [PMID:18487371]

348. Jin Y, Damaj BB and Maghazachi AA. (2005) Human resting CD16-, CD16+ and IL-2-, IL-12-, IL-15- or IFN-alpha-activated natural killer cells differentially respond to sphingosylphosphorylcholine, lysophosphatidylcholine and platelet-activating factor. Eur. J. Immunol. 35: 2699-708 [PMID:16078278]

349. Jockers R, Maurice P, Boutin JA and Delagrange P. (2008) Melatonin receptors, heterodimerization, signal transduction and binding sites: what's new? Br. J. Pharmacol. 154: 1182-95 [PMID:18493248]

350. Joensuu T, Hämäläinen R, Yuan B, Johnson C, Tegelberg S, Gasparini P, Zelante L, Pirvola U, Pakarinen $L$ and Lehesjoki $A E$ et al.. (2001) Mutations in a novel gene with transmembrane domains underlie Usher syndrome type 3. Am. J. Hum. Genet.69: 673-84 [PMID:11524702]

351. Johansson A, Helou K and Levan G. (1998) Cytogenetic localization of cancer-related genes in the rat and comparative mapping studies in human and mouse. Cytogenet. Cell Genet. 81: 217-21 [PMID:9730607]

352. John GW, Pauwels PJ, Perez M, Halazy S, Le Grand B, Verscheure Y, Valentin JP, Palmier C, Wurch T and Chopin P et al.. (1999) F 11356, a novel 5-hydroxytryptamine (5-HT) derivative with potent, selective, and unique high intrinsic activity at 5-HT1B/1D receptors in models relevant to migraine. J. Pharmacol. Exp. Ther. 290: 83-95 [PMID:10381763]

353. Johns DG, Behm DJ, Walker DJ, Ao Z, Shapland EM, Daniels DA, Riddick M, Dowell S, Staton PC, Green P, Shabon U, Bao W, Aiyar N, Yue TL, Brown AJ, Morrison AD and Douglas SA. (2007) The novel endocannabinoid receptor GPR55 is activated by atypical cannabinoids but does not mediate their vasodilator effects. Br. J. Pharmacol. 152: 825-31 [PMID:17704827]

354. Johnson LE, Elias MS, Bolick DT, Skaflen MD, Green RM and Hedrick CC. (2008) The G protein-coupled receptor G2A: involvement in hepatic lipid metabolism and gallstone formation in mice. Hepatology 48: 1138-48 [PMID:18821587] 
355. Jones PG, Nawoschik SP, Sreekumar K, Uveges AJ, Tseng E, Zhang L, Johnson J, He L, Paulsen JE, Bates B and Pausch MH. (2007) Tissue distribution and functional analyses of the constitutively active orphan G protein coupled receptors, GPR26 and GPR78. Biochim. Biophys. Acta 1770: 890-901 [PMID:17363172]

356. Jonsson L, Ljunggren E, Bremer A, Pedersen C, Landén M, Thuresson K, Giacobini M and Melke J. (2010) Mutation screening of melatonin-related genes in patients with autism spectrum disorders. BMC Med Genomics 3: 10 [PMID:20377855]

357. Juknat A, Pietr M, Kozela E, Rimmerman N, Levy R, Coppola G, Geschwind D and Vogel Z. (2012) Differential transcriptional profiles mediated by exposure to the cannabinoids cannabidiol and $\Delta 9$ tetrahydrocannabinol in BV-2 microglial cells. Br. J. Pharmacol. 165: 2512-28 [PMID:21542829]

358. Junaid MA, Kuizon S, Cardona J, Azher T, Murakami N, Pullarkat RK and Brown WT. (2011) Folic acid supplementation dysregulates gene expression in lymphoblastoid cells--implications in nutrition. Biochem. Biophys. Res. Commun. 412: 688-92 [PMID:21867686]

359. Jung BP, Nguyen T, Kolakowski LF, Lynch KR, Heng HH, George SR and O'Dowd BF. (1997) Discovery of a novel human G protein-coupled receptor gene (GPR25) located on chromosome 1. Biochem. Biophys. Res. Commun. 230: 69-72 [PMID:9020062]

360. Kabarowski JH, Zhu K, Le LQ, Witte ON and Xu Y. (2001) Lysophosphatidylcholine as a ligand for the immunoregulatory receptor G2A. Science 293: 702-5 [PMID:11474113]

361. Kamohara M, Matsuo A, Takasaki J, Kohda M, Matsumoto M, Matsumoto S, Soga T, Hiyama H, Kobori M and Katou M. (2005) Identification of MrgX2 as a human G-protein-coupled receptor for proadrenomedullin $\mathrm{N}$-terminal peptides. Biochem. Biophys. Res. Commun. 330: 1146-52 [PMID:15823563]

362. Kapas S, Catt KJ and Clark AJ. (1995) Cloning and expression of cDNA encoding a rat adrenomedullin receptor. J. Biol. Chem. 270: 25344-7 [PMID:7592696]

363. Kapur A, Zhao P, Sharir H, Bai Y, Caron MG, Barak LS and Abood ME. (2009) Atypical responsiveness of the orphan receptor GPR55 to cannabinoid ligands. J. Biol. Chem. 284: 29817-27 [PMID:19723626]

364. Kargl J, Balenga NA, Platzer W, Martini L, Whistler JL and Waldhoer M. (2012) The GPCR-associated sorting protein 1 regulates ligand-induced down-regulation of GPR55. Br. J. Pharmacol. 165: 2611-9 [PMID:21718301]

365. Kargl J, Brown AJ, Andersen L, Dorn G, Schicho R, Waldhoer M and Heinemann A. (2013) A selective antagonist reveals a potential role of $G$ protein-coupled receptor 55 in platelet and endothelial cell function. J. Pharmacol. Exp. Ther. 346: 54-66 [PMID:23639801]

366. Kashem SW, Subramanian H, Collington SJ, Magotti P, Lambris JD and Ali H. (2011) G protein coupled receptor specificity for C3a and compound 48/80-induced degranulation in human mast cells: roles of Masrelated genes MrgX1 and MrgX2. Eur. J. Pharmacol. 668: 299-304 [PMID:21741965]

367. Kato S, Matsubara M, Matsuo T, Mohri Y, Kazama I, Hatano R, Umezawa A and Nishimori K. (2006) Leucine-rich repeat-containing G protein-coupled receptor-4 (LGR4, Gpr48) is essential for renal development in mice. Nephron Exp. Nephrol. 104: e63-75 [PMID:16785743]

368. Kato S, Mohri Y, Matsuo T, Ogawa E, Umezawa A, Okuyama R and Nishimori K. (2007) Eye-open at birth phenotype with reduced keratinocyte motility in LGR4 null mice. FEBS Lett. 581: 4685-90 [PMID:17850793]

369. Katz LB, Gambale JJ, Rothenberg PL, Vanapalli SR, Vaccaro N, Xi L, Polidori DC, Vets E, Sarich TC and Stein PP. (2011) Pharmacokinetics, pharmacodynamics, safety, and tolerability of JNJ-38431055, a novel GPR119 receptor agonist and potential antidiabetes agent, in healthy male subjects. Clin. Pharmacol. Ther. 90: 685-92 [PMID:21975348]

370. Katz LB, Gambale JJ, Rothenberg PL, Vanapalli SR, Vaccaro N, Xi L, Sarich TC and Stein PP. (2012) Effects of JNJ-38431055, a novel GPR119 receptor agonist, in randomized, double-blind, placebocontrolled studies in subjects with type 2 diabetes. Diabetes Obes Metab14: 709-16 [PMID:22340428]

371. Kawasawa Y, Kume K, Izumi T and Shimizu T. (2000) Mammalian PSP24s (alpha and beta isoforms) are not responsive to lysophosphatidic acid in mammalian expression systems. Biochem. Biophys. Res. Commun. 276: 957-64 [PMID:11027575]

372. Kawasawa Y, Kume K, Nakade S, Haga H, Izumi T and Shimizu T. (2000) Brain-specific expression of novel G-protein-coupled receptors, with homologies to Xenopus PSP24 and human GPR45. Biochem. Biophys. Res. Commun. 276: 952-6 [PMID:11027574]

373. Kawasawa Y, McKenzie LM, Hill DP, Bono H, Yanagisawa M, RIKEN GER Group and GSL Members. (2003) G protein-coupled receptor genes in the FANTOM2 database. Genome Res. 13: 1466-77 [PMID:12819145]

374. Kelly LM, Pereira JP, Yi T, Xu Y and Cyster JG. (2011) EBI2 guides serial movements of activated B cells and ligand activity is detectable in lymphoid and nonlymphoid tissues. J. Immunol. 187: 3026-32 
[PMID:21844396]

375. Kennedy SP, Sun D, Oleynek JJ, Hoth CF, Kong J and Hill RJ. (1998) Expression of the rat adrenomedullin receptor or a putative human adrenomedullin receptor does not correlate with adrenomedullin binding or functional response. Biochem. Biophys. Res. Commun. 244: 832-7 [PMID:9535752]

376. Kerkhof HJ, Lories RJ, Meulenbelt I, Jonsdottir I, Valdes AM, Arp P, Ingvarsson T, Jhamai M, Jonsson H, Stolk L, Thorleifsson G, Zhai G, Zhang F, Zhu Y, van der Breggen R, Carr A, Doherty M, Doherty S, Felson DT, Gonzalez A, Halldorsson BV, Hart DJ, Hauksson VB, Hofman A, loannidis JP, Kloppenburg M, Lane NE, Loughlin J, Luyten FP, Nevitt MC, Parimi N, Pols HA, Rivadeneira F, Slagboom EP, Styrkársdóttir U, Tsezou A, van de Putte T, Zmuda J, Spector TD, Stefansson K, Uitterlinden AG and van Meurs JB. (2010) A genome-wide association study identifies an osteoarthritis susceptibility locus on chromosome 7q22. Arthritis Rheum. 62: 499-510 [PMID:20112360]

377. Kerschner JE, Hong W, Taylor SR, Kerschner JA, Khampang P, Wrege KC and North PE. (2013) A novel model of spontaneous otitis media with effusion (OME) in the Oxgr1 knock-out mouse. Int. J. Pediatr. Otorhinolaryngol. 77: 79-84 [PMID:23200873]

378. Kim KS, Ren J, Jiang Y, Ebrahem Q, Tipps R, Cristina K, Xiao YJ, Qiao J, Taylor KL and Lum łet al.. (2005) GPR4 plays a critical role in endothelial cell function and mediates the effects of sphingosylphosphorylcholine. FASEB J. 19: 819-21 [PMID:15857892]

379. Kim N, Park WY, Kim JM, Park YS, Lee DH, Park JH, Kim JS, Jung HC and Song IS. (2007) Analysis of Gene Expression Profile of AGS Cells Stimulated by Helicobacter pylori Adhesion. Gut Liver 1: 40-8 [PMID:20485657]

380. Kim SJ, Shon BH, Kang JH, Hahm KS, Yoo OJ, Park YS and Lee KK. (1997) Cloning of novel trinucleotide-repeat (CAG) containing genes in mouse brain. Biochem. Biophys. Res. Commun. 240: 23943 [PMID:9367917]

381. Kim SV, Xiang WV, Kwak C, Yang Y, Lin XW, Ota M, Sarpel U, Rifkin DB, Xu R and Littman DR. (2013) GPR15-mediated homing controls immune homeostasis in the large intestine mucosa. Science 340: 14569 [PMID:23661644]

382. Kimata JT, Gosink JJ, KewalRamani VN, Rudensey LM, Littman DR and Overbaugh J. (1999) Coreceptor specificity of temporal variants of simian immunodeficiency virus Mne. J. Virol.73: 1655-60 [PMID:9882375]

383. Kinoshita M, Takahashi $Y$ and Arikawa K. (2012) Simultaneous brightness contrast of foraging Papilio butterflies. Proc. Biol. Sci. 279: 1911-8 [PMID:22179808]

384. Kirby HR, Maguire JJ, Colledge WH and Davenport AP. (2010) International Union of Basic and Clinical Pharmacology. LXXVII. Kisspeptin receptor nomenclature, distribution, and function. Pharmacol. Rev. 62: 565-78 [PMID:21079036]

385. Kitamura H, Makide K, Shuto A, Ikubo M, Inoue A, Suzuki K, Sato Y, Nakamura S, Otani Y and Ohwada T et al.. (2012) GPR34 is a receptor for lysophosphatidylserine with a fatty acid at the sn-2 position $J$. Biochem. 151: 511-8 [PMID:22343749]

386. Kitao Y, Imai Y, Ozawa K, Kataoka A, Ikeda T, Soda M, Nakimawa K, Kiyama H, Stern DM, Hori O, Wakamatsu K, Ito S, Itohara S, Takahashi R and Ogawa S. (2007) Pael receptor induces death of dopaminergic neurons in the substantia nigra via endoplasmic reticulum stress and dopamine toxicity, which is enhanced under condition of parkin inactivation. Hum. Mol. Genet. 16: 50-60 [PMID:17116640]

387. Kluskens LD, Nelemans SA, Rink R, de Vries L, Meter-Arkema A, Wang Y, Walther T, Kuipers A, Moll GN and Haas M. (2009) Angiotensin-(1-7) with thioether bridge: an angiotensin-converting enzyme-resistant, potent angiotensin-(1-7) analog. J. Pharmacol. Exp. Ther. 328: 849-54 [PMID:19038778]

388. Kober P, Bujko M, Olędzki J, Tysarowski A and Siedlecki JA. (2011) Methyl-CpG binding column-based identification of nine genes hypermethylated in colorectal cancer. Mol. Carcinog. 50: 846-56 [PMID:21438024]

389. Kogure R, Toyama K, Hiyamuta S, Kojima I and Takeda S. (2011) 5-Hydroxy-eicosapentaenoic acid is an endogenous GPR119 agonist and enhances glucose-dependent insulin secretion. Biochem. Biophys. Res. Commun. 416: 58-63 [PMID:22079287]

390. Kohno M, Hasegawa H, Inoue A, Muraoka M, Miyazaki T, Oka K and Yasukawa M. (2006) Identification of $\mathrm{N}$-arachidonylglycine as the endogenous ligand for orphan G-protein-coupled receptor GPR18. Biochem. Biophys. Res. Commun. 347: 827-32 [PMID:16844083]

391. Koldehoff M, Zakrzewski JL, Klein-Hitpass L, Beelen DW and Elmaagacli AH. (2008) Gene profiling of growth factor independence 1B gene (Gfi-1B) in leukemic cells. Int. J. Hematol. 87: 39-47

[PMID:18224412]

392. Komarova SV, Pereverzev A, Shum JW, Sims SM and Dixon SJ. (2005) Convergent signaling by acidosis 
and receptor activator of NF-kappaB ligand (RANKL) on the calcium/calcineurin/NFAT pathway in osteoclasts. Proc. Natl. Acad. Sci. U.S.A. 102: 2643-8 [PMID:15695591]

393. Korstanje R, Desai J, Lazar G, King B, Rollins J, Spurr M, Joseph J, Kadambi S, Li Y, Cherry A, Matteson PG, Paigen B and Millonig JH. (2008) Quantitative trait loci affecting phenotypic variation in the vacuolated lens mouse mutant, a multigenic mouse model of neural tube defects. Physiol. Genomics 35: 296-304 [PMID:18796533]

394. Kostenis E. (2004) Novel clusters of receptors for sphingosine-1-phosphate, sphingosylphosphorylcholine, and (lyso)-phosphatidic acid: new receptors for "old" ligands. J. Cell. Biochem. 92: 923-36 [PMID:15258916]

395. Kostenis E, Milligan G, Christopoulos A, Sanchez-Ferrer CF, Heringer-Walther S, Sexton PM, Gembardt F, Kellett E, Martini L and Vanderheyden P et al.. (2005) G-protein-coupled receptor Mas is a physiological antagonist of the angiotensin II type 1 receptor. Circulation 111: 1806-13 [PMID:15809376]

396. Kotarsky K, Boketoft A, Bristulf J, Nilsson NE, Norberg A, Hansson S, Owman C, Sillard R, Leeb-Lundberg LM and Olde B. (2006) Lysophosphatidic acid binds to and activates GPR92, a G protein-coupled receptor highly expressed in gastrointestinal lymphocytes. J. Pharmacol. Exp. Ther. 318: 619-28 [PMID:16651401]

397. Kotsikorou E, Lynch DL, Abood ME and Reggio PH. (2011) Lipid bilayer molecular dynamics study of lipidderived agonists of the putative cannabinoid receptor, GPR55. Chem. Phys. Lipids 164: 131-43 [PMID:21185816]

398. Kotsikorou E, Madrigal KE, Hurst DP, Sharir H, Lynch DL, Heynen-Genel S, Milan LB, Chung TD, Seltzman HH and Bai Y et al.. (2011) Identification of the GPR55 agonist binding site using a novel set of high-potency GPR55 selective ligands. Biochemistry 50: 5633-47 [PMID:21534610]

399. Kottyan LC, Collier AR, Cao KH, Niese KA, Hedgebeth M, Radu CG, Witte ON, Khurana Hershey GK, Rothenberg ME and Zimmermann N. (2009) Eosinophil viability is increased by acidic pH in a CAMP-and GPR65-dependent manner. Blood 114: 2774-82 [PMID:19641187]

400. Kreitzer FR and Stella N. (2009) The therapeutic potential of novel cannabinoid receptors.Pharmacol. Ther. 122: 83-96 [PMID:19248809]

401. Kress M and Kuner R. (2009) Mode of action of cannabinoids on nociceptive nerve endings.Exp Brain Res 196: 79-88 [PMID:19306092]

402. Krieger NS and Bushinsky DA. (2011) Pharmacological inhibition of intracellular calcium release blocks acid-induced bone resorption. Am. J. Physiol. Renal Physiol.300: F91-7 [PMID:21048027]

403. Krishnamoorthy S, Recchiuti A, Chiang N, Fredman G and Serhan CN. (2012) Resolvin D1 receptor stereoselectivity and regulation of inflammation and proresolving microRNAs. Am. J. Pathol. 180: 2018-27 [PMID:22449948]

404. Krishnamoorthy S, Recchiuti A, Chiang N, Yacoubian S, Lee CH, Yang R, Petasis NA and Serhan CN. (2010) Resolvin D1 binds human phagocytes with evidence for proresolving receptors. Proc. Natl. Acad. Sci. U.S.A. 107: 1660-5 [PMID:20080636]

405. Krusche CA, Kroll T, Beier HM and Classen-Linke I. (2007) Expression of leucine-rich repeat-containing Gprotein-coupled receptors in the human cyclic endometrium. Fertil. Steril. 87: 1428-37 [PMID:17274992]

406. Ku GM, Pappalardo Z, Luo CC, German MS and McManus MT. (2012) An siRNA screen in pancreatic beta cells reveals a role for Gpr27 in insulin production. PLoS Genet. 8: e1002449 [PMID:22253604]

407. Kuc D, Zgrajka W, Parada-Turska J, Urbanik-Sypniewska T and Turski WA. (2008) Micromolar concentration of kynurenic acid in rat small intestine. Amino Acids 35: 503-5 [PMID:18235993]

408. Kuhmann SE, Madani N, Diop OM, Platt EJ, Morvan J, Müller-Trutwin MC, Barré-Sinoussi F and Kabat D. (2001) Frequent substitution polymorphisms in African green monkey CCR5 cluster at critical sites for infections by simian immunodeficiency virus SIVagm, implying ancient virus-host coevolution. J. Virol. 75: 8449-60 [PMID:11507190]

409. Kumar M, Grammas P, Giacomelli F and Wiener J. (1996) Selective expression of c-mas proto-oncogene in rat cerebral endothelial cells. Neuroreport 8: 93-6 [PMID:9051759]

410. Kyaw H, Zeng Z, Su K, Fan P, Shell BK, Carter KC and Li Y. (1998) Cloning, characterization, and mapping of human homolog of mouse T-cell death-associated gene. DNA Cell Biol. 17: 493-500 [PMID:9655242]

411. Labeguere FG, Nwesome GJR, Alvey LJ, Saniere LRM and Fletcher SR. (2013) Novel dihydropyrimidinoisoquinolinones and pharmaceutical compositions thereof for the treatment of inflammatory disorders Patent number: WO2013092791A1.

412. Ladenheim EE, Hamilton NL, Behles RR, Bi S, Hampton LL, Battey JF and Moran TH. (2008) Factors contributing to obesity in bombesin receptor subtype-3-deficient mice. Endocrinology 149: 971-8 [PMID:18039774]

413. Lambert DM and Muccioli GG. (2007) Endocannabinoids and related N-acylethanolamines in the control of 
appetite and energy metabolism: emergence of new molecular players. Curr Opin Clin Nutr Metab Care 10: 735-44 [PMID:18089956]

414. Lambot MA, Mendive F, Laurent P, Van Schoore G, Noël JC, Vanderhaeghen P and Vassart G. (2009) Three-dimensional reconstruction of efferent ducts in wild-type and Lgr4 knock-out mice. Anat Rec (Hoboken) 292: 595-603 [PMID:19301269]

415. Lan H, Lin HV, Wang CF, Wright MJ, Xu S, Kang L, Juhl K, Hedrick JA and Kowalski TJ. (2012) Agonists at GPR119 mediate secretion of GLP-1 from mouse enteroendocrine cells through glucose-independent pathways. Br. J. Pharmacol. 165: 2799-807 [PMID:22029751]

416. Lan H, Vassileva G, Corona A, Liu L, Baker H, Golovko A, Abbondanzo SJ, Hu W, Yang S and Ning Yet al.. (2009) GPR119 is required for physiological regulation of glucagon-like peptide-1 secretion but not for metabolic homeostasis. J. Endocrinol. 201: 219-30 [PMID:19282326]

417. Langlois AJ, Desrosiers RC, Lewis MG, KewalRamani VN, Littman DR, Zhou JY, Manson K, Wyand MS, Bolognesi DP and Montefiori DC. (1998) Neutralizing antibodies in sera from macaques immunized with attenuated simian immunodeficiency virus. J. Virol. 72: 6950-5 [PMID:9658152]

418. Lansu K, Karpiak J, Liu J, Huang XP, McCorvy JD, Kroeze WK, Che T, Nagase H, Carroll FI and Jin \&t al.. (2017) In silico design of novel probes for the atypical opioid receptor MRGPRX2.Nat. Chem. Biol. 13: 529-536 [PMID:28288109]

419. Lardner A. (2001) The effects of extracellular pH on immune function.J. Leukoc. Biol. 69: 522-30 [PMID:11310837]

420. Lattin JE, Schroder K, Su AI, Walker JR, Zhang J, Wiltshire T, Saijo K, Glass CK, Hume DA, Kellie S and Sweet MJ. (2008) Expression analysis of G Protein-Coupled Receptors in mouse macrophages. Immunome Res 4: 5 [PMID:18442421]

421. LaTulippe E, Satagopan J, Smith A, Scher H, Scardino P, Reuter V and Gerald WL. (2002) Comprehensive gene expression analysis of prostate cancer reveals distinct transcriptional programs associated with metastatic disease. Cancer Res. 62: 4499-506 [PMID:12154061]

422. Lauckner JE, Jensen JB, Chen HY, Lu HC, Hille B and Mackie K. (2008) GPR55 is a cannabinoid receptor that increases intracellular calcium and inhibits M current. Proc. Natl. Acad. Sci. U.S.A. 105: 2699-704 [PMID:18263732]

423. Lauffer L, lakoubov R and Brubaker PL. (2008) GPR119: "double-dipping" for better glycemic control. Endocrinology 149: 2035-7 [PMID:18427153]

424. Lauffer LM, lakoubov R and Brubaker PL. (2009) GPR119 is essential for oleoylethanolamide-induced glucagon-like peptide-1 secretion from the intestinal enteroendocrine L-cell. Diabetes 58: 1058-66 [PMID:19208912]

425. Lautner RQ, Villela DC, Fraga-Silva RA, Silva N, Verano-Braga T, Costa-Fraga F, Jankowski J, Jankowski V, Sousa F and Alzamora A et al.. (2013) Discovery and characterization of alamandine: a novel component of the Renin-Angiotensin system. Circ. Res. 112: 1104-11 [PMID:23446738]

426. Lauwers E, Landuyt B, Arckens L, Schoofs L and Luyten W. (2006) Obestatin does not activate orphan G protein-coupled receptor GPR39. Biochem. Biophys. Res. Commun. 351: 21-5 [PMID:17054911]

427. Le LQ, Kabarowski JH, Weng Z, Satterthwaite AB, Harvill ET, Jensen ER, Miller JF and Witte ON. (2001) Mice lacking the orphan $G$ protein-coupled receptor G2A develop a late-onset autoimmune syndrome. Immunity 14: 561-71 [PMID:11371358]

428. Le LQ, Kabarowski JH, Wong S, Nguyen K, Gambhir SS and Witte ON. (2002) Positron emission tomography imaging analysis of G2A as a negative modifier of lymphoid leukemogenesis initiated by the BCR-ABL oncogene. Cancer Cell 1: 381-91 [PMID:12086852]

429. Lecca D, Trincavelli ML, Gelosa P, Sironi L, Ciana P, Fumagalli M, Villa G, Verderio C, Grumelli C, Guerrini U, Tremoli E, Rosa P, Cuboni S, Martini C, Buffo A, Cimino M and Abbracchio MP. (2008) The recently identified P2Y-like receptor GPR17 is a sensor of brain damage and a new target for brain repair. PLOS ONE 3: e3579 [PMID:18974869]

430. Ledent C, Demeestere I, Blum D, Petermans J, Hämäläinen T, Smits G and Vassart G. (2005) Premature ovarian aging in mice deficient for Gpr3. Proc. Natl. Acad. Sci. U.S.A. 102: 8922-6 [PMID:15956199]

431. Lee CH. (2012) Resolvins as new fascinating drug candidates for inflammatory diseases.Arch. Pharm. Res. 35: 3-7 [PMID:22297737]

432. Lee CW, Rivera R, Gardell S, Dubin AE and Chun J. (2006) GPR92 as a new G12/13- and Gq-coupled lysophosphatidic acid receptor that increases cAMP, LPA5. J. Biol. Chem. 281: 23589-97 [PMID:16774927]

433. Lee DK, George SR, Cheng R, Nguyen T, Liu Y, Brown M, Lynch KR and O'Dowd BF. (2001) Identification of four novel human $G$ protein-coupled receptors expressed in the brain. Brain Res. Mol. Brain Res. 86: 13-22 [PMID:11165367] 
434. Lee DK, Lynch KR, Nguyen T, Im DS, Cheng R, Saldivia VR, Liu Y, Liu IS, Heng HH, Seeman P, George SR, O'Dowd BF and Marchese A. (2000) Cloning and characterization of additional members of the G protein-coupled receptor family. Biochim. Biophys. Acta 1490: 311-23 [PMID:10684976]

435. Lee DK, Nguyen T, Lynch KR, Cheng R, Vanti WB, Arkhitko O, Lewis T, Evans JF, George SR and O'Dowd BF. (2001) Discovery and mapping of ten novel G protein-coupled receptor genes. Gene 275: 8391 [PMID:11574155]

436. Lee HY, Shin EH and Bae YS. (2006) Sphingosylphosphorylcholine stimulates human monocyte-derived dendritic cell chemotaxis. Acta Pharmacol. Sin. 27: 1359-66 [PMID:17007744]

437. Lee J, Hever A, Willhite D, Zlotnik A and Hevezi P. (2005) Effects of RNA degradation on gene expression analysis of human postmortem tissues. FASEB J.19: 1356-8 [PMID:15955843]

438. Lee JE, Hong EJ, Nam HY, Kim JW, Han BG and Jeon JP. (2011) MicroRNA signatures associated with immortalization of EBV-transformed lymphoblastoid cell lines and their clinical traits. Cell Prolif. 44: 59-66 [PMID:21199010]

439. Lee MG, Dong X, Liu Q, Patel KN, Choi OH, Vonakis B and Undem BJ. (2008) Agonists of the MASrelated gene (Mrgs) orphan receptors as novel mediators of mast cell-sensory nerve interactions. J. Immunol. 180: 2251-5 [PMID:18250432]

440. Lee S, Bookout AL, Lee CE, Gautron L, Harper MJ, Elias CF, Lowell BB and Elmquist JK. (2012) Lasercapture microdissection and transcriptional profiling of the dorsomedial nucleus of the hypothalamus. $J$. Comp. Neurol. 520: 3617-32 [PMID:22473294]

441. Lee Z, Cheng CT, Zhang H, Subler MA, Wu J, Mukherjee A, Windle JJ, Chen CK and Fang X. (2008) Role of LPA4/p2y9/GPR23 in negative regulation of cell motility. Mol. Biol. Cell 19: 5435-45 [PMID:18843048]

442. Lembo PM, Grazzini E, Groblewski T, O'Donnell D, Roy MO, Zhang J, Hoffert C, Cao J, Schmidt R and Pelletier $\mathrm{M}$ et al.. (2002) Proenkephalin A gene products activate a new family of sensory neuron--specific GPCRs. Nat. Neurosci. 5: 201-9 [PMID:11850634]

443. Leng N, Gu G, Simerly RB and Spindel ER. (1999) Molecular cloning and characterization of two putative $G$ protein-coupled receptors which are highly expressed in the central nervous system. Brain Res. Mol. Brain Res. 69: 73-83 [PMID:10350639]

444. Leung T, Humbert JE, Stauffer AM, Giger KE, Chen H, Tsai HJ, Wang C, Mirshahi T and Robishaw JD. (2008) The orphan G protein-coupled receptor 161 is required for left-right patterning. Dev. Biol. 323: 3140 [PMID:18755178]

445. Levoye A, Dam J, Ayoub MA, Guillaume JL, Couturier C, Delagrange P and Jockers R. (2006) The orphan GPR50 receptor specifically inhibits MT1 melatonin receptor function through heterodimerization. EMBO J. 25: 3012-23 [PMID:16778767]

446. Lewis BP, Burge CB and Bartel DP. (2005) Conserved seed pairing, often flanked by adenosines, indicates that thousands of human genes are microRNA targets. Cell 120: 15-20 [PMID:15652477]

447. Li H, Wang D, Singh LS, Berk M, Tan H, Zhao Z, Steinmetz R, Kirmani K, Wei G and Xu Y. (2009) Abnormalities in osteoclastogenesis and decreased tumorigenesis in mice deficient for ovarian cancer $G$ protein-coupled receptor 1. PLoS ONE 4: e5705 [PMID:19479052]

448. Li J, Hand LE, Meng QJ, Loudon AS and Bechtold DA. (2011) GPR50 interacts with TIP60 to modulate glucocorticoid receptor signalling. PLoS ONE 6: e23725 [PMID:21858214]

449. Li Q, Estes JD, Duan L, Jessurun J, Pambuccian S, Forster C, Wietgrefe S, Zupancic M, Schacker T and Reilly $C$ et al.. (2008) Simian immunodeficiency virus-induced intestinal cell apoptosis is the underlying mechanism of the regenerative enteropathy of early infection. J. Infect. Dis. 197: 420-9 [PMID:18199035]

450. Liaw CW and Connolly DT. (2009) Sequence polymorphisms provide a common consensus sequence for GPR41 and GPR42. DNA Cell Biol. 28: 555-60 [PMID:19630535]

451. Liberles SD and Buck LB. (2006) A second class of chemosensory receptors in the olfactory epithelium. Nature 442: 645-650 [PMID:16878137]

452. Liebscher I, Müller U, Teupser D, Engemaier E, Engel KM, Ritscher L, Thor D, Sangkuhl K, Ricken A and Wurm $A$ et al.. (2011) Altered immune response in mice deficient for the $G$ protein-coupled receptor GPR34. J. Biol. Chem. 286: 2101-10 [PMID:21097509]

453. Lin G, Murphy SL, Gaulton GN and Hoxie JA. (2005) Modification of a viral envelope glycoprotein cell-cell fusion assay by utilizing plasmid encoded bacteriophage RNA polymerase. J. Virol. Methods 128: 135-42 [PMID:15941597]

454. Lin KN, Fang SH, Cai BL, Wang XX, Lu YB, Zhang WP and Wei EQ. (2009) [Construction and identification of eukaryotic expression vector of rat GPR17 gene]. Zhejiang Da Xue Xue Bao Yi Xue Ban 38: 584-90 [PMID:20014483]

455. Lin ME, Rivera RR and Chun J. (2012) Targeted deletion of LPA5 identifies novel roles for lysophosphatidic acid signaling in development of neuropathic pain. J. Biol. Chem. 287: 17608-17 
[PMID:22461625]

456. Lin $P$ and $Y e$ RD. (2003) The lysophospholipid receptor G2A activates a specific combination of $G$ proteins and promotes apoptosis. J. Biol. Chem. 278: 14379-86 [PMID:12586833]

457. Lin XH, Yuece B, Li YY, Feng YJ, Feng JY, Yu LY, Li K, Li YN and Storr M. (2011) A novel CB receptor GPR55 and its ligands are involved in regulation of gut movement in rodents. Neurogastroenterol. Motil. 23: 862-e342 [PMID:21726355]

458. Lin ZJ, Lu XM, Zhu TJ, Fang YC, Gu QQ and Zhu W. (2008) GPR12 selections of the metabolites from an endophytic Streptomyces sp. associated with Cistanches deserticola. Arch. Pharm. Res. 31: 1108-14 [PMID:18806952]

459. Liu C, Bonaventure P, Lee G, Nepomuceno D, Kuei C, Wu J, Li Q, Joseph V, Sutton SW and Eckert Wet al.. (2015) GPR139, an Orphan Receptor Highly Enriched in the Habenula and Septum, Is Activated by the Essential Amino Acids L-Tryptophan and L-Phenylalanine. Mol. Pharmacol. 88: 911-25 [PMID:26349500]

460. Liu C, Shi J, Badner JA, Zou H, Qian Y and Gershon ES. (2007) No association of trace amine receptor genes with bipolar disorder. Mol. Psychiatry 12: 979-81 [PMID:17957234]

461. Liu C, Yang XV, Wu J, Kuei C, Mani NS, Zhang L, Yu J, Sutton SW, Qin N and Banie Het al.. (2011) Oxysterols direct B-cell migration through EBI2. Nature 475: 519-23 [PMID:21796211]

462. Liu J, Lao ZJ, Zhang J, Schaeffer MT, Jiang MM, Guan XM, Van der Ploeg LH and Fong TM. (2002) Molecular basis of the pharmacological difference between rat and human bombesin receptor subtype-3 (BRS-3). Biochemistry 41: 8954-60 [PMID:12102638]

463. Liu JP, Komachi M, Tomura H, Mogi C, Damirin A, Tobo M, Takano M, Nochi H, Tamoto K, Sato K and Okajima F. (2010) Ovarian cancer G protein-coupled receptor 1-dependent and -independent vascular actions to acidic pH in human aortic smooth muscle cells. Am. J. Physiol. Heart Circ. Physiol.299: H73142 [PMID:20622109]

464. Liu JP, Nakakura T, Tomura H, Tobo M, Mogi C, Wang JQ, He XD, Takano M, Damirin A, Komachi M, Sato K and Okajima F. (2010) Each one of certain histidine residues in G-protein-coupled receptor GPR4 is critical for extracellular proton-induced stimulation of multiple G-protein-signaling pathways. Pharmacol. Res. 61: 499-505 [PMID:20211729]

465. Liu P, Lanza Jr TJ, Chioda M, Jones C, Chobanian HR, Guo Y, Chang L, Kelly TM, Kan Y and Palyha Cet al.. (2011) Discovery of benzodiazepine sulfonamide-based bombesin receptor subtype 3 agonists and their unusual chirality. ACS Med Chem Lett 2: 933-7 [PMID:24900283]

466. Liu P, Lu Y, Liu H, Wen W, Jia D, Wang Y and You M. (2012) Genome-wide association and fine mapping of genetic loci predisposing to colon carcinogenesis in mice. Mol. Cancer Res. 10: 66-74 [PMID:22127497]

467. Liu Q, Tang Z, Surdenikova L, Kim S, Patel KN, Kim A, Ru F, Guan Y, Weng HJ, Geng Y, Undem BJ, Kollarik M, Chen ZF, Anderson DJ and Dong X. (2009) Sensory neuron-specific GPCR Mrgprs are itch receptors mediating chloroquine-induced pruritus. Cell 139: 1353-65 [PMID:20004959]

468. Liu Y, Yang FC, Okuda T, Dong X, Zylka MJ, Chen CL, Anderson DJ, Kuner R and Ma Q. (2008) Mechanisms of compartmentalized expression of Mrg class G-protein-coupled sensory receptors. $J$. Neurosci. 28: 125-32 [PMID:18171930]

469. Lobo MK, Cui Y, Ostlund SB, Balleine BW and Yang XW. (2007) Genetic control of instrumental conditioning by striatopallidal neuron-specific S1P receptor Gpr6. Nat. Neurosci. 10: 1395-7 [PMID:17934457]

470. Logue SF, Grauer SM, Paulsen J, Graf R, Taylor N, Sung MA, Zhang L, Hughes Z, Pulito VL, Liu F, Rosenzweig-Lipson S, Brandon NJ, Marquis KL, Bates B and Pausch M. (2009) The orphan GPCR, GPR88, modulates function of the striatal dopamine system: a possible therapeutic target for psychiatric disorders? Mol. Cell. Neurosci. 42: 438-47 [PMID:19796684]

471. Loh ED, Broussard SR and Kolakowski LF. (2001) Molecular characterization of a novel glycoprotein hormone G-protein-coupled receptor. Biochem. Biophys. Res. Commun. 282: 757-64 [PMID:11401528]

472. Loh ED, Broussard SR, Liu Q, Copeland NG, Gilbert DJ, Jenkins NA and Kolakowski LF. (2000) Chromosomal localization of GPR48, a novel glycoprotein hormone receptor like GPCR, in human and mouse with radiation hybrid and interspecific backcross mapping. Cytogenet. Cell Genet. 89: 2-5 [PMID:10894923]

473. Lohr JG, Stojanov P, Lawrence MS, Auclair D, Chapuy B, Sougnez C, Cruz-Gordillo P, Knoechel B, Asmann YW and Slager SL et al.. (2012) Discovery and prioritization of somatic mutations in diffuse large B-cell lymphoma (DLBCL) by whole-exome sequencing. Proc. Natl. Acad. Sci. U.S.A. 109: 3879-84 [PMID:22343534]

474. Lu LF, Gavin MA, Rasmussen JP and Rudensky AY. (2007) G protein-coupled receptor 83 is dispensable for the development and function of regulatory T cells. Mol. Cell. Biol. 27: 8065-72 [PMID:17893329]

475. Luangsay S, Wittamer V, Bondue B, De Henau O, Rouger L, Brait M, Franssen JD, de Nadai P, Huaux F 
and Parmentier M. (2009) Mouse ChemR23 is expressed in dendritic cell subsets and macrophages, and mediates an anti-inflammatory activity of chemerin in a lung disease model. J. Immunol. 183: 6489-99 [PMID:19841182]

476. Lucas RJ, Hattar S, Takao M, Berson DM, Foster RG and Yau KW. (2003) Diminished pupillary light reflex at high irradiances in melanopsin-knockout mice. Science 299: 245-7 [PMID:12522249]

477. Ludewick HP, Schwab SG, Albus M, Lerer B, Maier W, Trixler M and Wildenauer DB. (2008) No support for an association with TAAR6 and schizophrenia in a linked population of European ancestry. Psychiatr. Genet. 18: 208-10 [PMID:18628684]

478. Ludwig MG, Vanek M, Guerini D, Gasser JA, Jones CE, Junker U, Hofstetter H, Wolf RM and Seuwen K. (2003) Proton-sensing G-protein-coupled receptors. Nature 425: 93-8 [PMID:12955148]

479. Lum H, Qiao J, Walter RJ, Huang F, Subbaiah PV, Kim KS and Holian O. (2003) Inflammatory stress increases receptor for lysophosphatidylcholine in human microvascular endothelial cells. Am. J. Physiol. Heart Circ. Physiol. 285: H1786-9 [PMID:12805023]

480. Lundin C, Hjorth L, Behrendtz M, Nordgren A, Palmqvist L, Andersen MK, Biloglav A, Forestier E, Paulsson K and Johansson B. (2012) High frequency of BTG1 deletions in acute lymphoblastic leukemia in children with down syndrome. Genes Chromosomes Cancer 51: 196-206 [PMID:22072402]

481. Luo J, Zhou W, Zhou X, Li D, Weng J, Yi Z, Cho SG, Li C, Yi T, Wu X, Li XY, de Crombrugghe B, Höök M and Liu M. (2009) Regulation of bone formation and remodeling by G-protein-coupled receptor 48. Development 136: 2747-56 [PMID:19605502]

482. Luo W, Wickramasinghe SR, Savitt JM, Griffin JW, Dawson TM and Ginty DD. (2007) A hierarchical NGF signaling cascade controls Ret-dependent and Ret-independent events during development of nonpeptidergic DRG neurons. Neuron 54: 739-54 [PMID:17553423]

483. Lyle R, Watanabe D, te Vruchte D, Lerchner W, Smrzka OW, Wutz A, Schageman J, Hahner L, Davies C and Barlow DP. (2000) The imprinted antisense RNA at the Igf2r locus overlaps but does not imprint Mas1. Nat. Genet. 25: 19-21 [PMID:10802648]

484. Macintyre DJ, McGhee KA, Maclean AW, Afzal M, Briffa K, Henry B, Thomson PA, Muir WJ and Blackwood DH. (2010) Association of GPR50, an X-linked orphan G protein-coupled receptor, and affective disorder in an independent sample of the Scottish population. Neurosci. Lett. 475: 169-73 [PMID:20371266]

485. Maekawa A, Balestrieri B, Austen KF and Kanaoka Y. (2009) GPR17 is a negative regulator of the cysteinyl leukotriene 1 receptor response to leukotriene D4. Proc. Natl. Acad. Sci. U.S.A. 106: 11685-90 [PMID:19561298]

486. Maekawa A, Xing W, Austen KF and Kanaoka Y. (2010) GPR17 regulates immune pulmonary inflammation induced by house dust mites. J. Immunol. 185: 1846-54 [PMID:20574000]

487. Maekawa F, Quah HM, Tanaka K and Ohki-Hamazaki H. (2004) Leptin resistance and enhancement of feeding facilitation by melanin-concentrating hormone in mice lacking bombesin receptor subtype-3. Diabetes 53: 570-6 [PMID:14988239]

488. Maghazachi AA, Knudsen E, Jin Y, Jenstad M and Chaudhry FA. (2004) D-galactosyl-beta1-1'sphingosine and D-glucosyl-beta1-1'-sphingosine induce human natural killer cell apoptosis. Biochem. Biophys. Res. Commun. 320: 810-5 [PMID:15240120]

489. Maguire JJ, Parker WA, Foord SM, Bonner TI, Neubig RR and Davenport AP. (2009) International Union of Pharmacology. LXXII. Recommendations for trace amine receptor nomenclature. Pharmacol. Rev. 61: 1-8 [PMID:19325074]

490. Mahadevan MS, Baird S, Bailly JE, Shutler GG, Sabourin LA, Tsilfidis C, Neville CE, Narang M and Korneluk RG. (1995) Isolation of a novel G protein-coupled receptor (GPR4) localized to chromosome 19q13.3. Genomics 30: 84-8 [PMID:8595909]

491. Malicki K, Malicka E, Bańbura MW, Niemiałtowski M and Ladyńska A. (1990) Electron microscopy, immune electron microscopy, enzyme immunoassay and immunofluorescent evaluation of rotaviruses isolated from individual calves and piglets. Acta Virol. 34: 523-8 [PMID:1983178]

492. Malik L, Kelly NM, Ma JN, Currier EA, Burstein ES and Olsson R. (2009) Discovery of non-peptidergic MrgX1 and MrgX2 receptor agonists and exploration of an initial SAR using solid-phase synthesis. Bioorg. Med. Chem. Lett. 19: 1729-32 [PMID:19230660]

493. Malone MH, Wang $Z$ and Distelhorst CW. (2004) The glucocorticoid-induced gene tdag8 encodes a proapoptotic $\mathrm{G}$ protein-coupled receptor whose activation promotes glucocorticoid-induced apoptosis. J. Biol. Chem. 279: 52850-9 [PMID:15485889]

494. Mantey SA, Coy DH, Entsuah LK and Jensen RT. (2004) Development of bombesin analogs with conformationally restricted amino acid substitutions with enhanced selectivity for the orphan receptor human bombesin receptor subtype 3. J. Pharmacol. Exp. Ther. 310: 1161-70 [PMID:15102928] 
495. Mantey SA, Coy DH, Pradhan TK, Igarashi H, Rizo IM, Shen L, Hou W, Hocart SJ and Jensen RT. (2001) Rational design of a peptide agonist that interacts selectively with the orphan receptor, bombesin receptor subtype 3. J. Biol. Chem. 276: 9219-29 [PMID:11112777]

496. Mantey SA, Weber HC, Sainz E, Akeson M, Ryan RR, Pradhan TK, Searles RP, Spindel ER, Battey JF and Coy DH et al.. (1997) Discovery of a high affinity radioligand for the human orphan receptor, bombesin receptor subtype 3 , which demonstrates that it has a unique pharmacology compared with other mammalian bombesin receptors. J. Biol. Chem. 272: 26062-71 [PMID:9325344]

497. Maravillas-Montero JL, Burkhardt AM, Hevezi PA, Carnevale CD, Smit MJ and Zlotnik A. (2015) Cutting edge: GPR35/CXCR8 is the receptor of the mucosal chemokine CXCL17. J. Immunol. 194: 29-33 [PMID:25411203]

498. Marazziti D, Di Pietro C, Golini E, Mandillo S, Matteoni R and Tocchini-Valentini GP. (2009) Induction of macroautophagy by overexpression of the Parkinson's disease-associated GPR37 receptor. FASEB J. 23: 1978-87 [PMID:19218498]

499. Marazziti D, Di Pietro C, Golini E, Mandillo S, Matteoni R and Tocchini-Valentini GP. (2009) Macroautophagy of the GPR37 orphan receptor and Parkinson disease-associated neurodegeneration. Autophagy 5: 741-2 [PMID:19398891]

500. Marazziti D, Di Pietro C, Mandillo S, Golini E, Matteoni R and Tocchini-Valentini GP. (2011) Absence of the GPR37/PAEL receptor impairs striatal Akt and ERK2 phosphorylation, DeltaFosB expression, and conditioned place preference to amphetamine and cocaine. FASEB J. 25: 2071-81 [PMID:21372109]

501. Marazziti D, Gallo A, Golini E, Matteoni R and Tocchini-Valentini GP. (1998) Molecular cloning and chromosomal localization of the mouse Gpr37 gene encoding an orphan G-protein-coupled peptide receptor expressed in brain and testis. Genomics 53: 315-24 [PMID:9799598]

502. Marazziti D, Golini E, Gallo A, Lombardi MS, Matteoni R and Tocchini-Valentini GP. (1997) Cloning of GPR37, a gene located on chromosome 7 encoding a putative G-protein-coupled peptide receptor, from a human frontal brain EST library. Genomics 45: 68-77 [PMID:9339362]

503. Marazziti D, Golini E, Mandillo S, Magrelli A, Witke W, Matteoni R and Tocchini-Valentini GP. (2004) Altered dopamine signaling and MPTP resistance in mice lacking the Parkinson's disease-associated GPR37/parkin-associated endothelin-like receptor. Proc. Natl. Acad. Sci. U.S.A. 101: 10189-94 [PMID:15218106]

504. Marazziti D, Mandillo S, Di Pietro C, Golini E, Matteoni R and Tocchini-Valentini GP. (2007) GPR37 associates with the dopamine transporter to modulate dopamine uptake and behavioral responses to dopaminergic drugs. Proc. Natl. Acad. Sci. U.S.A. 104: 9846-51 [PMID:17519329]

505. Marchese A, Nguyen T, Malik P, Xu S, Cheng R, Xie Z, Heng HH, George SR, Kolakowski LF and O'Dowd BF. (1998) Cloning genes encoding receptors related to chemoattractant receptors. Genomics 50: 281-6 [PMID:9653656]

506. Marchese A, Sawzdargo M, Nguyen T, Cheng R, Heng HH, Nowak T, Im DS, Lynch KR, George SR and O'dowd BF. (1999) Discovery of three novel orphan G-protein-coupled receptors. Genomics 56: 12-21 [PMID:10036181]

507. Maresca M, Mahfoud R, Garmy N, Kotler DP, Fantini J and Clayton F. (2003) The virotoxin model of HIV-1 enteropathy: involvement of GPR15/Bob and galactosylceramide in the cytopathic effects induced by HIV$1 \mathrm{gp} 120$ in the HT-29-D4 intestinal cell line. J. Biomed. Sci. 10: 156-66 [PMID:12566994]

508. Margulies BJ, Hauer DA and Clements JE. (2001) Identification and comparison of eleven rhesus macaque chemokine receptors. AIDS Res. Hum. Retroviruses 17: 981-6 [PMID:11461684]

509. Mario EG, Santos SH, Ferreira AV, Bader M, Santos RA and Botion LM. (2012) Angiotensin-(1-7) Masreceptor deficiency decreases peroxisome proliferator-activated receptor gamma expression in adipocytes. Peptides 33: 174-7 [PMID:22119778]

510. Martin KA, Grant SG and Hockfield S. (1992) The mas proto-oncogene is developmentally regulated in the rat central nervous system. Brain Res. Dev. Brain Res. 68: 75-82 [PMID:1521325]

511. Martin KA and Hockfield S. (1993) Expression of the mas proto-oncogene in the rat hippocampal formation is regulated by neuronal activity. Brain Res. Mol. Brain Res. 19: 303-9 [PMID:8231733]

512. Martínez A, Elsasser TH, Muro-Cacho C, Moody TW, Miller MJ, Macri CJ and Cuttitta F. (1997) Expression of adrenomedullin and its receptor in normal and malignant human skin: a potential pluripotent role in the integument. Endocrinology 138: 5597-604 [PMID:9389548]

513. Martínez A, Miller MJ, Catt KJ and Cuttitta F. (1997) Adrenomedullin receptor expression in human lung and in pulmonary tumors. J. Histochem. Cytochem. 45: 159-64 [PMID:9016306]

514. Maruyama $T$, Miyamoto $\mathrm{Y}$, Nakamura $T$, Tamai $\mathrm{Y}$, Okada $\mathrm{H}$, Sugiyama $E$, Nakamura $\mathrm{T}$, Itadani $\mathrm{H}$ and Tanaka K. (2002) Identification of membrane-type receptor for bile acids (M-BAR). Biochem. Biophys. Res. Commun. 298: 714-9 [PMID:12419312] 
515. Mascitti V, Stevens BD, Choi C, McClure KF, Guimarães CR, Farley KA, Munchhof MJ, Robinson RP, Futatsugi $\mathrm{K}$ and Lavergne SY et al.. (2011) Design and evaluation of a 2-(2,3,6-trifluorophenyl)acetamide derivative as an agonist of the GPR119 receptor. Bioorg. Med. Chem. Lett. 21: 1306-9 [PMID:21310611]

516. Massart R, Guilloux JP, Mignon V, Sokoloff P and Diaz J. (2009) Striatal GPR88 expression is confined to the whole projection neuron population and is regulated by dopaminergic and glutamatergic afferents. Eur. J. Neurosci. 30: 397-414 [PMID:19656174]

517. Matsufuji T, Shimada K, Kobayashi S, Ichikawa M, Kawamura A, Fujimoto T, Arita T, Hara T, Konishi M and Abe-Ohya $R$ et al.. (2015) Synthesis and biological evaluation of novel chiral diazepine derivatives as bombesin receptor subtype-3 (BRS-3) agonists incorporating an antedrug approach. Bioorg. Med. Chem. 23: 89-104 [PMID:25497965]

518. Matsufuji T, Shimada K, Kobayashi S, Kawamura A, Fujimoto T, Arita T, Hara T, Konishi M, Abe-Ohya R and Izumi M et al.. (2014) Discovery of novel chiral diazepines as bombesin receptor subtype-3 (BRS-3) agonists with low brain penetration. Bioorg. Med. Chem. Lett. 24: 750-5 [PMID:24412111]

519. Matsumoto K, Yoshitomi T, Ishimoto Y, Tanaka N, Takahashi K, Watanabe A and Chiba K. (2018) DS8500a, an Orally Available G Protein-Coupled Receptor 119 Agonist, Upregulates Glucagon-Like Peptide1 and Enhances Glucose-Dependent Insulin Secretion and Improves Glucose Homeostasis in Type 2 Diabetic Rats. J. Pharmacol. Exp. Ther. 367: 509-517 [PMID:30217957]

520. Matsumoto M, Beltaifa S, Weickert CS, Herman MM, Hyde TM, Saunders RC, Lipska BK, Weinberger DR and Kleinman JE. (2005) A conserved mRNA expression profile of SREB2 (GPR85) in adult human, monkey, and rat forebrain. Brain Res. Mol. Brain Res. 138: 58-69 [PMID:15893849]

521. Matsumoto M, Saito T, Takasaki J, Kamohara M, Sugimoto T, Kobayashi M, Tadokoro M, Matsumoto S, Ohishi T and Furuichi K. (2000) An evolutionarily conserved G-protein coupled receptor family, SREB, expressed in the central nervous system. Biochem. Biophys. Res. Commun. 272: 576-82 [PMID:10833454]

522. Matsumoto M, Straub RE, Marenco S, Nicodemus KK, Matsumoto S, Fujikawa A, Miyoshi S, Shobo M, Takahashi S, Yarimizu J, Yuri M, Hiramoto M, Morita S, Yokota H, Sasayama T, Terai K, Yoshino M, Miyake A, Callicott JH, Egan MF, Meyer-Lindenberg A, Kempf L, Honea R, Vakkalanka RK, Takasaki J, Kamohara M, Soga T, Hiyama H, Ishii H, Matsuo A, Nishimura S, Matsuoka N, Kobori M, Matsushime $H$, Katoh M, Furuichi K and Weinberger DR. (2008) The evolutionarily conserved G protein-coupled receptor SREB2/GPR85 influences brain size, behavior, and vulnerability to schizophrenia. Proc. Natl. Acad. Sci. U.S.A. 105: 6133-8 [PMID:18413613]

523. Matsuo A, Matsumoto S, Nagano M, Masumoto KH, Takasaki J, Matsumoto M, Kobori M, Katoh M and Shigeyoshi Y. (2005) Molecular cloning and characterization of a novel Gq-coupled orphan receptor GPRg1 exclusively expressed in the central nervous system. Biochem. Biophys. Res. Commun. 331: 3639 [PMID:15845401]

524. Matsuzaki S, Ishizuka T, Yamada H, Kamide Y, Hisada T, Ichimonji I, Aoki H, Yatomi M, Komachi M and Tsurumaki $\mathrm{H}$ et al.. (2011) Extracellular acidification induces connective tissue growth factor production through proton-sensing receptor OGR1 in human airway smooth muscle cells. Biochem. Biophys. Res. Commun. 413: 499-503 [PMID:21907704]

525. Matteson PG, Desai J, Korstanje R, Lazar G, Borsuk TE, Rollins J, Kadambi S, Joseph J, Rahman T, Wink J, Benayed R, Paigen B and Millonig JH. (2008) The orphan G protein-coupled receptor, Gpr161, encodes the vacuolated lens locus and controls neurulation and lens development. Proc. Natl. Acad. Sci. U.S.A. 105: 2088-93 [PMID:18250320]

526. Mazerbourg S, Bouley DM, Sudo S, Klein CA, Zhang JV, Kawamura K, Goodrich LV, Rayburn H, TessierLavigne $M$ and Hsueh AJ. (2004) Leucine-rich repeat-containing, G protein-coupled receptor 4 null mice exhibit intrauterine growth retardation associated with embryonic and perinatal lethality. Mol. Endocrinol. 18: 2241-54 [PMID:15192078]

527. McClure KF, Darout E, Guimarães CR, DeNinno MP, Mascitti V, Munchhof MJ, Robinson RP, Kohrt J, Harris AR and Moore DE et al.. (2011) Activation of the G-protein-coupled receptor 119: a conformationbased hypothesis for understanding agonist response. J. Med. Chem. 54: 1948-52 [PMID:21361292]

528. McCormick MB, Coulombe PA and Fuchs E. (1991) Sorting out IF networks: consequences of domain swapping on IF recognition and assembly. J. Cell Biol. 113: 1111-24 [PMID:1710225]

529. McGuire J, Herman JP, Ghosal S, Eaton K, Sallee FR and Sah R. (2009) Acid-sensing by the T cell deathassociated gene 8 (TDAG8) receptor cloned from rat brain. Biochem. Biophys. Res. Commun. 386: 420-5 [PMID:19501050]

530. McHugh D. (2012) GPR18 in microglia: implications for the CNS and endocannabinoid system signalling. Br. J. Pharmacol. 167: 1575-82 [PMID:22563843]

531. McHugh D, Hu SS, Rimmerman N, Juknat A, Vogel Z, Walker JM and Bradshaw HB. (2010) N- 
arachidonoyl glycine, an abundant endogenous lipid, potently drives directed cellular migration through GPR18, the putative abnormal cannabidiol receptor. BMC Neurosci 11: 44 [PMID:20346144]

532. McHugh D, Page J, Dunn E and Bradshaw HB. (2012) $\Delta(9)$-Tetrahydrocannabinol and N-arachidonyl glycine are full agonists at GPR18 receptors and induce migration in human endometrial HEC-1B cells. Br. J. Pharmacol. 165: 2414-24 [PMID:21595653]

533. McKee KK, Tan CP, Palyha OC, Liu J, Feighner SD, Hreniuk DL, Smith RG, Howard AD and Van der Ploeg LH. (1997) Cloning and characterization of two human G protein-coupled receptor genes (GPR38 and GPR39) related to the growth hormone secretagogue and neurotensin receptors. Genomics 46: 42634 [PMID:9441746]

534. McNeil BD, Pundir P, Meeker S, Han L, Undem BJ, Kulka M and Dong X. (2015) Identification of a mastcell-specific receptor crucial for pseudo-allergic drug reactions. Nature 519: 237-41 [PMID:25517090]

535. McPartland JM, Glass M, Matias I, Norris RW and Kilpatrick CW. (2007) A shifted repertoire of endocannabinoid genes in the zebrafish (Danio rerio). Mol. Genet. Genomics 277: 555-70 [PMID:17256142]

536. McPartland JM, Matias I, Di Marzo V and Glass M. (2006) Evolutionary origins of the endocannabinoid system. Gene 370: 64-74 [PMID:16434153]

537. McPartland JM, Norris RW and Kilpatrick CW. (2007) Tempo and mode in the endocannaboinoid system. J. Mol. Evol. 65: 267-76 [PMID:17676365]

538. Meder W, Wendland M, Busmann A, Kutzleb C, Spodsberg N, John H, Richter R, Schleuder D, Meyer M and Forssmann WG. (2003) Characterization of human circulating TIG2 as a ligand for the orphan receptor ChemR23. FEBS Lett. 555: 495-9 [PMID:14675762]

539. Mehlmann LM, Saeki Y, Tanaka S, Brennan TJ, Evsikov AV, Pendola FL, Knowles BB, Eppig JJ and Jaffe LA. (2004) The Gs-linked receptor GPR3 maintains meiotic arrest in mammalian oocytes. Science 306: 1947-50 [PMID:15591206]

540. Mendive F, Laurent P, Van Schoore G, Skarnes W, Pochet R and Vassart G. (2006) Defective postnatal development of the male reproductive tract in LGR4 knockout mice. Dev. Biol. 290: 421-34 [PMID:16406039]

541. Metzger JM, Gagen K, Raustad KA, Yang L, White A, Wang SP, Craw S, Liu P, Lanza T and Lin LSet al.. (2010) Body temperature as a mouse pharmacodynamic response to bombesin receptor subtype-3 agonists and other potential obesity treatments. Am. J. Physiol. Endocrinol. Metab. 299: E816-24 [PMID:20807840]

542. Metzger R, Bader M, Ludwig T, Berberich C, Bunnemann B and Ganten D. (1995) Expression of the mouse and rat mas proto-oncogene in the brain and peripheral tissues. FEBS Lett. 357: 27-32 [PMID:8001672]

543. Meyer RC, Giddens MM, Schaefer SA and Hall RA. (2013) GPR37 and GPR37L1 are receptors for the neuroprotective and glioprotective factors prosaptide and prosaposin. Proc. Natl. Acad. Sci. U.S.A.110: 9529-34 [PMID:23690594]

544. Meyer zu Heringdorf D and Jakobs KH. (2007) Lysophospholipid receptors: signalling, pharmacology and regulation by lysophospholipid metabolism. Biochim. Biophys. Acta 1768: 923-40 [PMID:17078925]

545. Milasta S, Pediani J, Appelbe S, Trim S, Wyatt M, Cox P, Fidock M and Milligan G. (2006) Interactions between the Mas-related receptors MrgD and MrgE alter signalling and trafficking of MrgD. Mol. Pharmacol. 69: 479-91 [PMID:16282220]

546. Miller MJ, Martínez A, Unsworth EJ, Thiele CJ, Moody TW, Elsasser T and Cuttitta F. (1996) Adrenomedullin expression in human tumor cell lines. Its potential role as an autocrine growth factor. $J$. Biol. Chem. 271: 23345-51 [PMID:8798536]

547. Min KD, Asakura M, Liao Y, Nakamaru K, Okazaki H, Takahashi T, Fujimoto K, Ito S, Takahashi A, Asanuma H, Yamazaki S, Minamino T, Sanada S, Seguchi O, Nakano A, Ando Y, Otsuka T, Furukawa H, Isomura T, Takashima S, Mochizuki N and Kitakaze M. (2010) Identification of genes related to heart failure using global gene expression profiling of human failing myocardium. Biochem. Biophys. Res. Commun. 393: 55-60 [PMID:20100464]

548. Miyagi T, Chuang LF, Doi RH, Carlos MP, Torres JV and Chuang RY. (2000) Morphine induces gene expression of CCR5 in human CEMx174 lymphocytes. J. Biol. Chem. 275: 31305-10 [PMID:10887175]

549. Mizushima K, Miyamoto Y, Tsukahara F, Hirai M, Sakaki Y and Ito T. (2000) A novel G-protein-coupled receptor gene expressed in striatum. Genomics 69: 314-21 [PMID:11056049]

550. Moechars D, Depoortere I, Moreaux B, de Smet B, Goris I, Hoskens L, Daneels G, Kass S, Ver Donck L, Peeters T and Coulie B. (2006) Altered gastrointestinal and metabolic function in the GPR39-obestatin receptor-knockout mouse. Gastroenterology 131: 1131-41 [PMID:17030183]

551. Mogi C, Tobo M, Tomura H, Murata N, He XD, Sato K, Kimura T, Ishizuka T, Sasaki T, Sato T, Kihara Y, 
Ishii S, Harada A and Okajima F. (2009) Involvement of proton-sensing TDAG8 in extracellular acidification-induced inhibition of proinflammatory cytokine production in peritoneal macrophages. $J$. Immunol. 182: 3243-51 [PMID:19234222]

552. Mogi C, Tomura H, Tobo M, Wang JQ, Damirin A, Kon J, Komachi M, Hashimoto K, Sato K and Okajima F. (2005) Sphingosylphosphorylcholine antagonizes proton-sensing ovarian cancer G-protein-coupled receptor 1 (OGR1)-mediated inositol phosphate production and cAMP accumulation. J. Pharmacol. Sci. 99: 160-7 [PMID:16210776]

553. Mohebbi N, Benabbas C, Vidal S, Daryadel A, Bourgeois S, Velic A, Ludwig MG, Seuwen K and Wagner CA. (2012) The proton-activated G protein coupled receptor OGR1 acutely regulates the activity of epithelial proton transport proteins. Cell. Physiol. Biochem. 29: 313-24 [PMID:22508039]

554. Mohri Y, Kato S, Umezawa A, Okuyama R and Nishimori K. (2008) Impaired hair placode formation with reduced expression of hair follicle-related genes in mice lacking Lgr4. Dev. Dyn. 237: 2235-42 [PMID:18651655]

555. Mohri Y, Oyama K, Akamatsu A, Kato S and Nishimori K. (2011) Lgr4-deficient mice showed premature differentiation of ureteric bud with reduced expression of Wnt effector Lef1 and Gata3. Dev. Dyn. 240: 1626-34 [PMID:21523854]

556. Mohri Y, Umezu T, Hidema S, Tomisawa H, Akamatsu A, Kato S, Nawa A and Nishimori K. (2010) Reduced fertility with impairment of early-stage embryos observed in mice lacking Lgr4 in epithelial tissues. Fertil. Steril. 94: 2878-81 [PMID:20638054]

557. Monnot C, Weber V, Stinnakre J, Bihoreau C, Teutsch B, Corvol P and Clauser E. (1991) Cloning and functional characterization of a novel mas-related gene, modulating intracellular angiotensin II actions. Mol. Endocrinol. 5: 1477-87 [PMID:1723144]

558. Montpetit A and Sinnett D. (1999) Physical mapping of the G-protein coupled receptor 19 (GPR19) in the chromosome 12p12.3 region frequently rearranged in cancer cells. Hum. Genet. 105: 162-4 [PMID:10480372]

559. Montuenga LM, Martínez A, Miller MJ, Unsworth EJ and Cuttitta F. (1997) Expression of adrenomedullin and its receptor during embryogenesis suggests autocrine or paracrine modes of action. Endocrinology 138: $440-51$ [PMID:8977434]

560. Moody TW, Mantey SA, Moreno P, Nakamura T, Lacivita E, Leopoldo M and Jensen RT. (2015) ML-18 is a non-peptide bombesin receptor subtype-3 antagonist which inhibits lung cancer growth. Peptides 64: 5561 [PMID:25554218]

561. Moody TW, Sancho V, di Florio A, Nuche-Berenguer B, Mantey S and Jensen RT. (2011) Bombesin receptor subtype-3 agonists stimulate the growth of lung cancer cells and increase EGF receptor tyrosine phosphorylation. Peptides 32: 1677-84 [PMID:21712056]

562. Moreno P, Mantey SA, Nuche-Berenguer B, Reitman ML, Gonzalez N, , Coy DH and Jensen RT. (2013) Comparative Pharmacology of Bombesin Receptor Subtype-3, Nonpeptide Agonist MK-5046, a Universal Peptide Agonist, and Peptide Antagonist Bantag-1 for Human Bombesin Receptors. Pharmacol Exp Therap 347: 100-116 [PMID:23892571]

563. Moreno-Navarrete JM, Catalán V, Whyte L, Díaz-Arteaga A, Vázquez-Martínez R, Rotellar F, Guzmán R, Gómez-Ambrosi J, Pulido MR and Russell WR et al.. (2012) The L-a-lysophosphatidylinositol/GPR55 system and its potential role in human obesity. Diabetes 61: 281-91 [PMID:22179809]

564. Morita H, Mazerbourg S, Bouley DM, Luo CW, Kawamura K, Kuwabara Y, Baribault H, Tian H and Hsueh AJ. (2004) Neonatal lethality of LGR5 null mice is associated with ankyloglossia and gastrointestinal distension. Mol. Cell. Biol. 24: 9736-43 [PMID:15509778]

565. Mudipalli A, Owen RD and Preston RJ. (2005) The effect of arsenicals on ultraviolet-radiation-induced growth arrest and related signaling events in human keratinocytes. Int. J. Oncol. 27: 769-78 [PMID:16077927]

566. Mullighan CG, Collins-Underwood JR, Phillips LA, Loudin MG, Liu W, Zhang J, Ma J, Coustan-Smith E, Harvey RC, Willman CL, Mikhail FM, Meyer J, Carroll AJ, Williams RT, Cheng J, Heerema NA, Basso G, Pession A, Pui CH, Raimondi SC, Hunger SP, Downing JR, Carroll WL and Rabin KR. (2009) Rearrangement of CRLF2 in B-progenitor- and Down syndrome-associated acute lymphoblastic leukemia. Nat. Genet. 41: 1243-6 [PMID:19838194]

567. Murakami M, Shiraishi A, Tabata K and Fujita N. (2008) Identification of the orphan GPCR, P2Y(10) receptor as the sphingosine-1-phosphate and lysophosphatidic acid receptor. Biochem. Biophys. Res. Commun. 371: 707-12 [PMID:18466763]

568. Murakami N, Yokomizo T, Okuno T and Shimizu T. (2004) G2A is a proton-sensing G-protein-coupled receptor antagonized by lysophosphatidylcholine. J. Biol. Chem. 279: 42484-91 [PMID:15280385]

569. Murakami T, Shoji M, Imai Y, Inoue H, Kawarabayashi T, Matsubara E, Harigaya Y, Sasaki A, Takahashi 
R and Abe K. (2004) Pael-R is accumulated in Lewy bodies of Parkinson's disease. Ann. Neurol. 55: 43942 [PMID:14991825]

570. Murata N, Mogi C, Tobo M, Nakakura T, Sato K, Tomura H and Okajima F. (2009) Inhibition of superoxide anion production by extracellular acidification in neutrophils. Cell. Immunol. 259: 21-6 [PMID:19539899]

571. Mustata RC, Van Loy T, Lefort A, Libert F, Strollo S, Vassart G and Garcia MI. (2011) Lgr4 is required for Paneth cell differentiation and maintenance of intestinal stem cells ex vivo. EMBO Rep. 12: 558-64 [PMID:21508962]

572. Mårtensson UE, Salehi SA, Windahl S, Gomez MF, Swärd K, Daszkiewicz-Nilsson J, Wendt A, Andersson N, Hellstrand P and Grände PO et al.. (2009) Deletion of the G protein-coupled receptor 30 impairs glucose tolerance, reduces bone growth, increases blood pressure, and eliminates estradiol-stimulated insulin release in female mice. Endocrinology 150: 687-98 [PMID:18845638]

573. Mörner A, Björndal A, Albert J, Kewalramani VN, Littman DR, Inoue R, Thorstensson R, Fenyö EM and Björling E. (1999) Primary human immunodeficiency virus type 2 (HIV-2) isolates, like HIV-1 isolates, frequently use CCR5 but show promiscuity in coreceptor usage. J. Virol. 73: 2343-9 [PMID:9971817]

574. Müller A, Kleinau G, Piechowski CL, Müller TD, Finan B, Pratzka J, Grüters A, Krude H, Tschöp M and Biebermann H. (2013) G-protein coupled receptor 83 (GPR83) signaling determined by constitutive and zinc(II)-induced activity. PLoS ONE 8: e53347 [PMID:23335960]

575. Müller A, Leinweber B, Fischer J, Müller TD, Grüters A, Tschöp MH, Knäuper V, Biebermann H and Kleinau G. (2014) The extracellular N-terminal domain of G-protein coupled receptor 83 regulates signaling properties and is an intramolecular inverse agonist. BMC Res Notes 7: 913 [PMID:25516095]

576. Naderi N, Majidi M, Mousavi Z, Khoramian Tusi S, Mansouri Z and Khodagholi F. (2012) The interaction between intrathecal administration of low doses of palmitoylethanolamide and AM251 in formalin-induced pain related behavior and spinal cord IL1- $\beta$ expression in rats. Neurochem. Res. 37: 778-85 [PMID:22201038]

577. Nakahara T, Kuroki T, Ohta E, Kajihata T, Yamada H, Yamanaka M, Hashimoto K, Tsutsumi T, Hirano M and Uchimura H. (2003) Effect of the neurotoxic dose of methamphetamine on gene expression of parkin and Pael-receptors in rat striatum. Parkinsonism Relat. Disord. 9: 213-9 [PMID:12618056]

578. Nakahata T, Tokumaru K, Ito Y, Ishii N, Setoh M, Shimizu Y, Harasawa T and Aoyama K. Design and Synthesis of 1-(1-Benzothiophen-7-yl)-1H-Pyrazole, a Novel Series of G Protein-coupled Receptor 52 (GPR52) Agonists. Bioorganic \& Medicinal Chemistry

579. Nakamichi Y, Wada E, Aoki K, Ohara-Imaizumi M, Kikuta T, Nishiwaki C, Matsushima S, Watanabe T, Wada K and Nagamatsu S. (2004) Functions of pancreatic beta cells and adipocytes in bombesin receptor subtype-3-deficient mice. Biochem. Biophys. Res. Commun. 318: 698-703 [PMID:15144894]

580. Nambu H, Fukushima M, Hikichi H, Inoue T, Nagano N, Tahara Y, Nambu T, Ito J, Ogawa Y and Ozaki S et al.. (2011) Characterization of metabolic phenotypes of mice lacking GPR61, an orphan G-protein coupled receptor. Life Sci. 89: 765-72 [PMID:21971119]

581. Nath M, Offers M, Hummel M and Seissler J. (2011) Isolation and in vitro expansion of Lgr6-positive multipotent hair follicle stem cells. Cell Tissue Res. 344: 435-44 [PMID:21484413]

582. Negoro K, Yonetoku Y, Maruyama T, Yoshida S, Takeuchi M and Ohta M. (2012) Synthesis and structureactivity relationship of 4-amino-2-phenylpyrimidine derivatives as a series of novel GPR119 agonists.

Bioorg. Med. Chem. 20: 2369-75 [PMID:22365911]

583. Neubig RR. (2010) Mind your salts: when the inactive constituent isn't.Mol. Pharmacol. 78: 558-9 [PMID:20651116]

584. Nguyen LP, Pan J, Dinh TT, Hadeiba H, O'Hara 3rd E, Ebtikar A, Hertweck A, Gökmen MR, Lord GM and Jenner RG et al.. (2015) Role and species-specific expression of colon T cell homing receptor GPR15 in colitis. Nat. Immunol. 16: 207-13 [PMID:25531831]

585. Niedernberg A, Tunaru S, Blaukat A, Ardati A and Kostenis E. (2003) Sphingosine 1-phosphate and dioleoylphosphatidic acid are low affinity agonists for the orphan receptor GPR63. Cell. Signal. 15: 435-46 [PMID:12618218]

586. Nikaido Y, Koyama Y, Yoshikawa Y, Furuya T and Takeda S. (2015) Mutation analysis and molecular modeling for the investigation of ligand-binding modes of GPR84. J. Biochem. 157: 311-20 [PMID:25425658]

587. Ning Y, O'Neill K, Lan H, Pang L, Shan LX, Hawes BE and Hedrick JA. (2008) Endogenous and synthetic agonists of GPR119 differ in signalling pathways and their effects on insulin secretion in MIN6c4 insulinoma cells. Br. J. Pharmacol. 155: 1056-65 [PMID:18724386]

588. No authors listed. (2010) Deal watch: Metabolex and Sanofi-Aventis partner on GPCR agonists for type 2 diabetes. Nat Rev Drug Discov9: 670 [PMID:20811370]

589. No authors listed. (2005) Sphingosylphosphorylcholine and lysophosphatidylcholine are ligands for the G 
protein-coupled receptor GPR4. (Retraction). J. Biol. Chem. 280: 43280 [PMID:16498716]

590. Noguchi K, Ishii S and Shimizu T. (2003) Identification of p2y9/GPR23 as a novel G protein-coupled receptor for lysophosphatidic acid, structurally distant from the Edg family. J. Biol. Chem. 278: 25600-6 [PMID:12724320]

591. Nothacker HP, Wang Z, Zeng H, Mahata SK, O'Connor DT and Civelli O. (2005) Proadrenomedullin Nterminal peptide and cortistatin activation of MrgX2 receptor is based on a common structural motif. Eur. J. Pharmacol. 519: 191-3 [PMID:16111673]

592. O'Dowd BF, Nguyen T, Jung BP, Marchese A, Cheng R, Heng HH, Kolakowski LF, Lynch KR and George SR. (1997) Cloning and chromosomal mapping of four putative novel human G-protein-coupled receptor genes. Gene 187: 75-81 [PMID:9073069]

593. O'Dowd BF, Nguyen T, Lynch KR, Kolakowski LF, Thompson M, Cheng R, Marchese A, Ng G, Heng HH and George SR. (1996) A novel gene codes for a putative $G$ protein-coupled receptor with an abundant expression in brain. FEBS Lett. 394: 325-9 [PMID:8830667]

594. O'Dowd BF, Nguyen T, Marchese A, Cheng R, Lynch KR, Heng HH, Kolakowski Jr LF and George SR. (1998) Discovery of three novel G-protein-coupled receptor genes. Genomics 47: 310-3 [PMID:9479505]

595. Obara Y, Ueno S, Yanagihata Y and Nakahata N. (2011) Lysophosphatidylinositol causes neurite retraction via GPR55, G13 and RhoA in PC12 cells. PLoS ONE 6: e24284 [PMID:21904624]

596. Obinata H, Hattori T, Nakane S, Tatei K and Izumi T. (2005) Identification of 9-hydroxyoctadecadienoic acid and other oxidized free fatty acids as ligands of the $\mathrm{G}$ protein-coupled receptor G2A. J. Biol. Chem. 280: 40676-83 [PMID:16236715]

597. Ocón B, Pan J, Dinh TT, Chen W, Ballet R, Bscheider M, Habtezion A, Tu H, Zabel BA and Butcher EC. (2017) A Mucosal and Cutaneous Chemokine Ligand for the Lymphocyte Chemoattractant Receptor GPR15. Front Immuno/8: 1111 [PMID:28936214]

598. Offermanns S, Colletti SL, Lovenberg TW, Semple G, Wise A and IJzerman AP. (2011) International Union of Basic and Clinical Pharmacology. LXXXII: Nomenclature and Classification of Hydroxy-carboxylic Acid Receptors (GPR81, GPR109A, and GPR109B). Pharmacol. Rev. 63: 269-90 [PMID:21454438]

599. Ogawa A, Obinata H, Hattori T, Kishi M, Tatei K, Ishikawa $O$ and Izumi T. (2010) Identification and analysis of two splice variants of human G2A generated by alternative splicing. J. Pharmacol. Exp. Ther. 332: 469-78 [PMID:19855098]

600. Ohagen A, Devitt A, Kunstman KJ, Gorry PR, Rose PP, Korber B, Taylor J, Levy R, Murphy RL, Wolinsky SM and Gabuzda D. (2003) Genetic and functional analysis of full-length human immunodeficiency virus type 1 env genes derived from brain and blood of patients with AIDS. J. Virol. 77: 12336-45 [PMID:14581570]

601. Ohki-Hamazaki H, Wada E, Matsui K and Wada K. (1997) Cloning and expression of the neuromedin B receptor and the third subtype of bombesin receptor genes in the mouse. Brain Res. 762: 165-72 [PMID:9262170]

602. Ohki-Hamazaki H, Watase K, Yamamoto K, Ogura H, Yamano M, Yamada K, Maeno H, Imaki J, Kikuyama $S$ and Wada E et al.. (1997) Mice lacking bombesin receptor subtype-3 develop metabolic defects and obesity. Nature 390: 165-9 [PMID:9367152]

603. Oka S, Kimura S, Toshida T, Ota R, Yamashita A and Sugiura T. (2010) Lysophosphatidylinositol induces rapid phosphorylation of p38 mitogen-activated protein kinase and activating transcription factor 2 in HEK293 cells expressing GPR55 and IM-9 lymphoblastoid cells. J. Biochem. 147: 671-8 [PMID:20051382]

604. Oka S, Nakajima K, Yamashita A, Kishimoto S and Sugiura T. (2007) Identification of GPR55 as a lysophosphatidylinositol receptor. Biochem. Biophys. Res. Commun. 362: 928-34 [PMID:17765871]

605. Oka S, Ota R, Shima M, Yamashita A and Sugiura T. (2010) GPR35 is a novel lysophosphatidic acid receptor. Biochem. Biophys. Res. Commun. 395: 232-7 [PMID:20361937]

606. Oka S, Toshida T, Maruyama K, Nakajima K, Yamashita A and Sugiura T. (2009) 2-Arachidonoyl-snglycero-3-phosphoinositol: a possible natural ligand for GPR55. J. Biochem. 145: 13-20 [PMID:18845565]

607. Okamoto Y, Bernstein JD and Shikano S. (2013) Role of C-terminal membrane-proximal basic residues in cell surface trafficking of HIV coreceptor GPR15 protein. J. Biol. Chem. 288: 9189-99 [PMID:23430259]

608. Okamoto $Y$ and Shikano S. (2011) Phosphorylation-dependent C-terminal binding of 14-3-3 proteins promotes cell surface expression of HIV co-receptor GPR15. J. Biol. Chem. 286: 7171-81 [PMID:21189250]

609. Okubo S, Kurebayashi J, Otsuki T, Yamamoto Y, Tanaka K and Sonoo H. (2004) Additive antitumour effect of the epidermal growth factor receptor tyrosine kinase inhibitor gefitinib (Iressa, ZD1839) and the antioestrogen fulvestrant (Faslodex, ICl 182,780) in breast cancer cells. Br. J. Cancer90: 236-44 [PMID:14710235]

610. Okuno T and Yokomizo T. (2011) What is the natural ligand of GPR55?J. Biochem. 149: 495-7 
[PMID:21324983]

611. Onozawa Y, Fujita Y, Kuwabara H, Nagasaki M, Komai T and Oda T. (2012) Activation of T cell deathassociated gene 8 regulates the cytokine production of T cells and macrophages in vitro. Eur. $J$. Pharmacol. 683: 325-31 [PMID:22445881]

612. Osborn O, Oh da Y, McNelis J, Sanchez-Alavez M, Talukdar S, Lu M, Li P, Thiede L, Morinaga H and Kim JJ et al.. (2012) G protein-coupled receptor 21 deletion improves insulin sensitivity in diet-induced obese mice. J. Clin. Invest. 122: 2444-53 [PMID:22653059]

613. Osmers I, Smith SS, Parks BW, Yu S, Srivastava R, Wohler JE, Barnum SR and Kabarowski JH. (2009) Deletion of the G2A receptor fails to attenuate experimental autoimmune encephalomyelitis. $J$. Neuroimmunol. 207: 18-23 [PMID:19135725]

614. Ota T, Suzuki Y, Nishikawa T, Otsuki T, Sugiyama T, Irie R, Wakamatsu A, Hayashi K, Sato H and Nagai $\mathrm{K}$ et al.. (2004) Complete sequencing and characterization of 21,243 full-length human cDNAs.Nat. Genet. 36: 40-5 [PMID:14702039]

615. Overton HA, Babbs AJ, Doel SM, Fyfe MC, Gardner LS, Griffin G, Jackson HC, Procter MJ, Rasamison CM and Tang-Christensen M et al.. (2006) Deorphanization of a G protein-coupled receptor for oleoylethanolamide and its use in the discovery of small-molecule hypophagic agents. Cell Metab. 3: 16775 [PMID:16517404]

616. Owen SM, Masciotra S, Novembre F, Yee J, Switzer WM, Ostyula M and Lal RB. (2000) Simian immunodeficiency viruses of diverse origin can use CXCR4 as a coreceptor for entry into human cells. J. Virol. 74: 5702-8 [PMID:10823878]

617. Oyama K, Mohri Y, Sone M, Nawa A and Nishimori K. (2011) Conditional knockout of Lgr4 leads to impaired ductal elongation and branching morphogenesis in mouse mammary glands. Sex Dev 5: 205-12 [PMID:21791950]

618. Padmanabhan S, Myers AG and Prasad BM. (2009) Constitutively active GPR6 is located in the intracellular compartments. FEBS Lett. 583: 107-12 [PMID:19059244]

619. Pae CU, Drago A, Forlani M, Patkar AA and Serretti A. (2010) Investigation of an epistastic effect between a set of TAAR6 and HSP-70 genes variations and major mood disorders. Am. J. Med. Genet. B Neuropsychiatr. Genet. 153B: 680-3 [PMID:19582769]

620. Pae CU, Drago A, Kim JJ, Patkar AA, Jun TY, De Ronchi D and Serretti A. (2010) TAAR6 variations possibly associated with antidepressant response and suicidal behavior. Psychiatry Res 180: 20-4 [PMID:20493543]

621. Pae CU, Drago A, Mandelli L, De Ronchi D and Serretti A. (2009) TAAR 6 and HSP-70 variations associated with bipolar disorder. Neurosci. Lett. 465: 257-61 [PMID:19766166]

622. Pae CU, Drago A, Patkar AA, Jun TY and Serretti A. (2009) Epistasis between a set of variations located in the TAAR6 and HSP-70 genes toward schizophrenia and response to antipsychotic treatment. Eur Neuropsychopharmacol 19: 806-11 [PMID:19643584]

623. Pae CU, Yu HS, Amann D, Kim JJ, Lee CU, Lee SJ, Jun TY, Lee C, Paik IH and Patkar AAet al.. (2008) Association of the trace amine associated receptor 6 (TAAR6) gene with schizophrenia and bipolar disorder in a Korean case control sample. J Psychiatr Res 42: 35-40 [PMID:17097106]

624. Pappo AS, Krailo M, Chen Z, Rodriguez-Galindo C and Reaman G. (2010) Infrequent tumor initiative of the Children's Oncology Group: initial lessons learned and their impact on future plans. J. Clin. Oncol. 28: 5011-6 [PMID:20956621]

625. Pariani MJ, Spencer A, Graham JM and Rimoin DL. (2009) A 785kb deletion of 3p14.1p13, including the FOXP1 gene, associated with speech delay, contractures, hypertonia and blepharophimosis. Eur J Med Genet 52: 123-7 [PMID:19332160]

626. Park SJ, Lee SJ, Nam SY and Im DS. (2018) GPR35 mediates lodoxamide-induced migration inhibitory response but not CXCL17-induced migration stimulatory response in THP-1 cells; is GPR35 a receptor for CXCL17? Br. J. Pharmacol. 175: 154-161 [PMID:29068046]

627. Parker HE, Habib AM, Rogers GJ, Gribble FM and Reimann F. (2009) Nutrient-dependent secretion of glucose-dependent insulinotropic polypeptide from primary murine K cells. Diabetologia 52: 289-98 [PMID:19082577]

628. Parker R, Liu M, Eyre HJ, Copeland NG, Gilbert DJ, Crawford J, Sutherland GR, Jenkins NA and Herzog H. (2000) Y-receptor-like genes GPR72 and GPR73: molecular cloning, genomic organisation and assignment to human chromosome 11q21.1 and 2p14 and mouse chromosome 9 and 6. Biochim. Biophys. Acta 1491: 369-75 [PMID:10760605]

629. Parks BW, Gambill GP, Lusis AJ and Kabarowski JH. (2005) Loss of G2A promotes macrophage accumulation in atherosclerotic lesions of low density lipoprotein receptor-deficient mice. J. Lipid Res. 46: 1405-15 [PMID:15834123] 
630. Parks BW, Lusis AJ and Kabarowski JH. (2006) Loss of the lysophosphatidylcholine effector, G2A, ameliorates aortic atherosclerosis in low-density lipoprotein receptor knockout mice. Arterioscler. Thromb. Vasc. Biol. 26: 2703-9 [PMID:16990555]

631. Parks BW, Srivastava R, Yu S and Kabarowski JH. (2009) ApoE-dependent modulation of HDL and atherosclerosis by G2A in LDL receptor-deficient mice independent of bone marrow-derived cells.

Arterioscler. Thromb. Vasc. Biol. 29: 539-47 [PMID:19164809]

632. Parravicini C, Ranghino G, Abbracchio MP and Fantucci P. (2008) GPR17: molecular modeling and dynamics studies of the 3-D structure and purinergic ligand binding features in comparison with P2Y receptors. BMC Bioinformatics 9: 263 [PMID:18533035]

633. Pasternack SM, von Kügelgen I, Aboud KA, Lee YA, Rüschendorf F, Voss K, Hillmer AM, Molderings GJ, Franz T, Ramirez A, Nürnberg P, Nöthen MM and Betz RC. (2008) G protein-coupled receptor P2Y5 and its ligand LPA are involved in maintenance of human hair growth. Nat. Genet. 40: $329-34$ [PMID:18297070]

634. Pease JE. (2011) Targeting chemokine receptors in allergic disease. Biochem. J. 434: 11-24 [PMID:21269275]

635. Pease JE. (2006) Tails of the unexpected - an atypical receptor for the chemokine RANTES/CCL5 expressed in brain. Br. J. Pharmacol. 149: 460-2 [PMID:17001302]

636. Peiró C, Vallejo S, Gembardt F, Azcutia V, Heringer-Walther S, Rodríguez-Mañas L, Schultheiss HP, Sánchez-Ferrer CF and Walther T. (2007) Endothelial dysfunction through genetic deletion or inhibition of the G protein-coupled receptor Mas: a new target to improve endothelial function. J. Hypertens. 25: 2421-5 [PMID:17984663]

637. Pereira JP, Kelly LM, Xu Y and Cyster JG. (2009) EBI2 mediates B cell segregation between the outer and centre follicle. Nature 460: 1122-6 [PMID:19597478]

638. Pereverzev A, Komarova SV, Korcok J, Armstrong S, Tremblay GB, Dixon SJ and Sims SM. (2008) Extracellular acidification enhances osteoclast survival through an NFAT-independent, protein kinase Cdependent pathway. Bone 42: 150-61 [PMID:17964236]

639. Perry KJ, Johnson VR, Malloch EL, Fukui L, Wever J, Thomas AG, Hamilton PW and Henry JJ. (2010) The G-protein-coupled receptor, GPR84, is important for eye development in Xenopus laevis. Dev. Dyn. 239: 3024-37 [PMID:20925114]

640. Pertwee RG. (2007) GPR55: a new member of the cannabinoid receptor clan?Br. J. Pharmacol. 152: 9846 [PMID:17876300]

641. Pertwee RG. (2010) Receptors and channels targeted by synthetic cannabinoid receptor agonists and antagonists. Curr. Med. Chem. 17: 1360-81 [PMID:20166927]

642. Pertwee RG, Howlett AC, Abood ME, Alexander SP, Di Marzo V, Elphick MR, Greasley PJ, Hansen HS, Kunos $G$ and Mackie K et al.. (2010) International Union of Basic and Clinical Pharmacology. LXXIX. Cannabinoid receptors and their ligands: beyond $\mathrm{CB}_{1}$ and $\mathrm{CB}_{2}$. Pharmacol. Rev. 62: 588-631 [PMID:21079038]

643. Pesini P, Detheux M, Parmentier M and Hökfelt T. (1998) Distribution of a glucocorticoid-induced orphan receptor (JP05) mRNA in the central nervous system of the mouse. Brain Res. Mol. Brain Res.57: 281300 [PMID:9675427]

644. Petek E, Windpassinger C, Simma B, Mueller T, Wagner K and Kroisel PM. (2003) Molecular characterisation of a $15 \mathrm{Mb}$ constitutional de novo interstitial deletion of chromosome $3 p$ in a boy with developmental delay and congenital anomalies. J. Hum. Genet. 48: 283-7 [PMID:12836054]

645. Peter C, Waibel M, Radu CG, Yang LV, Witte ON, Schulze-Osthoff K, Wesselborg S and Lauber K. (2008) Migration to apoptotic "find-me" signals is mediated via the phagocyte receptor G2A. J. Biol. Chem. 283: 5296-305 [PMID:18089568]

646. Petersen PS, Jin C, Madsen AN, Rasmussen M, Kuhre R, Egerod KL, Nielsen LB, Schwartz TW and Holst B. (2011) Deficiency of the GPR39 receptor is associated with obesity and altered adipocyte metabolism. FASEB J. 25: 3803-14 [PMID:21784784]

647. Petitet F, Donlan M and Michel A. (2006) GPR55 as a new cannabinoid receptor: still a long way to prove it. Chem Biol Drug Des 67: 252-3 [PMID:16611220]

648. Peukert S, Hughes R, Nunez J, He G, Yan Z, Jain R, Llamas L, Luchansky S, Carlson A and Liang @t al.. (2014) Discovery of 2-Pyridylpyrimidines as the First Orally Bioavailable GPR39 Agonists ACS Med Chem Lett 5: 1114-8 [PMID:25313322]

649. Pietr M, Kozela E, Levy R, Rimmerman N, Lin YH, Stella N, Vogel Z and Juknat A. (2009) Differential changes in GPR55 during microglial cell activation. FEBS Lett. 583: 2071-6 [PMID:19464294]

650. Pillaiyar T, Köse M, Namasivayam V, Sylvester K, Borges G, Thimm D, Von Kügelen I and Müller CE. (2018) 6-(Ar)Alkylamino-Substituted Uracil Derivatives: Lipid Mimetics with Potent Activity at the Orphan G Protein-Coupled Receptor 84 (GPR84) ACS Omega 3: 3365-3383 
651. Pinheiro SV, Ferreira AJ, Kitten GT, da Silveira KD, da Silva DA, Santos SH, Gava E, Castro CH, Magalhães JA and da Mota RK et al.. (2009) Genetic deletion of the angiotensin-(1-7) receptor Mas leads to glomerular hyperfiltration and microalbuminuria. Kidney Int. 75: 1184-93 [PMID:19262461]

652. Pinheiro SV, Simões e Silva AC, Sampaio WO, de Paula RD, Mendes EP, Bontempo ED, Pesquero JB, Walther T, Alenina N and Bader M et al.. (2004) Nonpeptide AVE 0991 is an angiotensin-(1-7) receptor Mas agonist in the mouse kidney. Hypertension 44: 490-6 [PMID:15326087]

653. Pisabarro MT, Leung B, Kwong M, Corpuz R, Frantz GD, Chiang N, Vandlen R, Diehl LJ, Skelton N and Kim HS et al.. (2006) Cutting edge: novel human dendritic cell- and monocyte-attracting chemokine-like protein identified by fold recognition methods. J. Immunol. 176: 2069-73 [PMID:16455961]

654. Pitkin SL, Maguire JJ, Bonner TI and Davenport AP. (2010) International Union of Basic and Clinical Pharmacology. LXXIV. Apelin receptor nomenclature, distribution, pharmacology, and function. Pharmacol. Rev. 62: 331-42 [PMID:20605969]

655. Piñeiro R, Maffucci T and Falasca M. (2011) The putative cannabinoid receptor GPR55 defines a novel autocrine loop in cancer cell proliferation. Oncogene 30: 142-52 [PMID:20838378]

656. Prchalová E, Hin N, Thomas AG, Veeravalli V, Ng J, Alt J, Rais R, Rojas C, Li Z and Hihara Het al.. (2019) Discovery of Benzamidine- and 1-Aminoisoquinoline-Based Human MAS-Related G-Protein-Coupled Receptor X1 (MRGPRX1) Agonists. J. Med. Chem. 62: 8631-8641 [PMID:31498617]

657. Pringle KG, Tadros MA, Callister RJ and Lumbers ER. (2011) The expression and localization of the human placental prorenin/renin-angiotensin system throughout pregnancy: roles in trophoblast invasion and angiogenesis? Placenta 32: 956-62 [PMID:22018415]

658. Prossnitz ER and Barton M. (2011) The G-protein-coupled estrogen receptor GPER in health and disease. Nat Rev Endocrinol 7: 715-26 [PMID:21844907]

659. Pugliese AM, Trincavelli ML, Lecca D, Coppi E, Fumagalli M, Ferrario S, Failli P, Daniele S, Martini C, Pedata F and Abbracchio MP. (2009) Functional characterization of two isoforms of the P2Y-like receptor GPR17: [35S]GTPgammaS binding and electrophysiological studies in 1321N1 cells. Am. J. Physiol., Cell Physiol. 297: C1028-40 [PMID:19625605]

660. Pukhlik BM, Mzaiĕk V and Zaikov SV. (1991) [Clinico-immunological characteristics of drug allergy in patients with pulmonary tuberculosis]. Probl Tuberk 46-7 [PMID:1838178]

661. Pöhlmann S, Davis C, Meister S, Leslie GJ, Otto C, Reeves JD, Puffer BA, Papkalla A, Krumbiegel M and Marzi A et al.. (2004) Amino acid 324 in the simian immunodeficiency virus SIVmac V3 loop can confer CD4 independence and modulate the interaction with CCR5 and alternative coreceptors. J. Virol. 78: 322332 [PMID:15016843]

662. Pöhlmann S, Krumbiegel M and Kirchhoff F. (1999) Coreceptor usage of BOB/GPR15 and Bonzo/STRL33 by primary isolates of human immunodeficiency virus type 1. J. Gen. Virol. 80 ( Pt 5): 1241-51 [PMID:10355771]

663. Pöhlmann S, Lee B, Meister S, Krumbiegel M, Leslie G, Doms RW and Kirchhoff F. (2000) Simian immunodeficiency virus utilizes human and sooty mangabey but not rhesus macaque STRL33 for efficient entry. J. Virol. 74: 5075-82 [PMID:10799581]

664. Pöhlmann S, Stolte N, Münch J, Ten Haaft P, Heeney JL, Stahl-Hennig C and Kirchhoff F. (1999) Coreceptor usage of BOB/GPR15 in addition to CCR5 has no significant effect on replication of simian immunodeficiency virus in vivo. J. Infect. Dis. 180: 1494-502 [PMID:10515808]

665. Qi AD, Harden TK and Nicholas RA. (2013) Is GPR17 a P2Y/leukotriene receptor? examination of uracil nucleotides, nucleotide sugars, and cysteinyl leukotrienes as agonists of GPR17. J. Pharmacol. Exp. Ther. 347: 38-46 [PMID:23908386]

666. QI LL, LU YB, SHI WZ, ZHAO CZ, ZHANG YM, CHEN LP, ZHANG LH, FANG SH, BAO JF, SHEN JG and WEI EQ. (2009) [Preparation and identification of a polyclonal antibody against novel cysteinyl leukotriene receptor GPR17]. Zhejiang Da Xue Xue Bao Yi Xue Barß8: 357-61 [PMID:19693972]

667. Qi X, Tang J, Pramanik R, Schultz RM, Shirasawa S, Sasazuki T, Han J and Chen G. (2004) p38 MAPK activation selectively induces cell death in K-ras-mutated human colon cancer cells through regulation of vitamin D receptor. J. Biol. Chem. 279: 22138-44 [PMID:15037631]

668. Qiao J, Huang F, Naikawadi RP, Kim KS, Said T and Lum H. (2006) Lysophosphatidylcholine impairs endothelial barrier function through the G protein-coupled receptor GPR4. Am. J. Physiol. Lung Cell Mol. Physiol. 291: L91-101 [PMID:16461426]

669. Qin X, Qu X, Coy D and Weber HC. (2012) A selective human bombesin receptor subtype-3 peptide agonist mediates CREB phosphorylation and transactivation. J. Mol. Neurosci. 46: 88-99 [PMID:22127929]

670. Qin Y, Verdegaal EM, Siderius M, Bebelman JP, Smit MJ, Leurs R, Willemze R, Tensen CP and Osanto S. (2011) Quantitative expression profiling of G-protein-coupled receptors (GPCRs) in metastatic melanoma: the constitutively active orphan GPCR GPR18 as novel drug target. Pigment Cell Melanoma Res 24: 207- 
18 [PMID:20880198]

671. Qu L and Caterina MJ. (2018) Accelerating the reversal of inflammatory pain with NPD1 and its receptor GPR37. J. Clin. Invest. 128: 3246-3249 [PMID:30010628]

672. Rabelo LA, Xu P, Todiras M, Sampaio WO, Buttgereit J, Bader M, Santos RA and Alenina N. (2008) Ablation of angiotensin (1-7) receptor Mas in C57BI/6 mice causes endothelial dysfunction. J Am SoC Hypertens 2: 418-24 [PMID:20409925]

673. Rabin M, Birnbaum D, Young D, Birchmeier C, Wigler M and Ruddle FH. (1987) Human ros1 and mas1 oncogenes located in regions of chromosome 6 associated with tumor-specific rearrangements. Oncogene Res. 1: 169-78 [PMID:3329713]

674. Radu CG, Cheng D, Nijagal A, Riedinger M, McLaughlin J, Yang LV, Johnson J and Witte ON. (2006) Normal immune development and glucocorticoid-induced thymocyte apoptosis in mice deficient for the Tcell death-associated gene 8 receptor. Mol. Cell. Biol. 26: 668-77 [PMID:16382156]

675. Radu CG, Nijagal A, McLaughlin J, Wang L and Witte ON. (2005) Differential proton sensitivity of related G protein-coupled receptors T cell death-associated gene 8 and G2A expressed in immune cells. Proc. Natl. Acad. Sci. U.S.A. 102: 1632-7 [PMID:15665078]

676. Radu CG, Yang LV, Riedinger M, Au M and Witte ON. (2004) T cell chemotaxis to lysophosphatidylcholine through the G2A receptor. Proc. Natl. Acad. Sci. U.S.A. 101: 245-50 [PMID:14681556]

677. Rajagopal S, Kim J, Ahn S, Craig S, Lam CM, Gerard NP, Gerard C and Lefkowitz RJ. (2010) Betaarrestin- but not G protein-mediated signaling by the "decoy" receptor CXCR7. Proc. Natl. Acad. Sci. U.S.A. 107: 628-32 [PMID:20018651]

678. Rakušan D, Bürgelová M, Vaněčková I, Vaňourková Z, Husková Z, Skaroupková P, Mrázová I, Opočenský M, Kramer HJ and Netuka I et al.. (2010) Knockout of angiotensin 1-7 receptor Mas worsens the course of two-kidney, one-clip Goldblatt hypertension: roles of nitric oxide deficiency and enhanced vascular responsiveness to angiotensin II. Kidney Blood Press. Res. 33: 476-88 [PMID:21071955]

679. Ramachandran V, Arumugam T, Hwang RF, Greenson JK, Simeone DM and Logsdon CD. (2007) Adrenomedullin is expressed in pancreatic cancer and stimulates cell proliferation and invasion in an autocrine manner via the adrenomedullin receptor, ADMR. Cancer Res. 67: 2666-75 [PMID:17363587]

680. Ramachandran V, Arumugam T, Langley R, Hwang RF, Vivas-Mejia P, Sood AK, Lopez-Berestein G and Logsdon CD. (2009) The ADMR receptor mediates the effects of adrenomedullin on pancreatic cancer cells and on cells of the tumor microenvironment. PLOS ONE 4: e7502 [PMID:19847298]

681. Ramos-Álvarez I, Martín-Duce A, Moreno-Villegas Z, Sanz R, Aparicio C, Portal-Núñez S, Mantey SA, Jensen RT and González N. (2013) Bombesin receptor subtype-3 (BRS-3), a novel candidate as therapeutic molecular target in obesity and diabetes. Mol. Cell. Endocrinol. 367: 109-15 [PMID:23291341]

682. Rao A and Herr DR. (2017) G protein-coupled receptor GPR19 regulates E-cadherin expression and invasion of breast cancer cells. Biochim. Biophys. Acta 1864: 1318-1327 [PMID:28476646]

683. Rao S, Garrett-Sinha LA, Yoon J and Simon MC. (1999) The Ets factors PU.1 and Spi-B regulate the transcription in vivo of P2Y10, a lymphoid restricted heptahelical receptor. J. Biol. Chem. 274: 34245-52 [PMID:10567398]

684. Rau KK, Mcllwrath SL, Wang H, Lawson JJ, Jankowski MP, Zylka MJ, Anderson DJ and Koerber HR. (2009) Mrgprd enhances excitability in specific populations of cutaneous murine polymodal nociceptors. $J$. Neurosci. 29: 8612-9 [PMID:19571152]

685. Redell MS, Tsimelzon A, Hilsenbeck SG and Tweardy DJ. (2007) Conditional overexpression of Stat3alpha in differentiating myeloid cells results in neutrophil expansion and induces a distinct, antiapoptotic and pro-oncogenic gene expression pattern. J. Leukoc. Biol. 82: 975-85 [PMID:17634277]

686. Ren H, Orozco IJ, Su Y, Suyama S, Gutiérrez-Juárez R, Horvath TL, Wardlaw SL, Plum L, Arancio O and Accili D. (2012) FoxO1 Target Gpr17 Activates AgRP Neurons to Regulate Food Intake. Cell 149: 1314-26 [PMID:22682251]

687. Ren J and Zhang L. (2011) Effects of ovarian cancer G protein coupled receptor 1 on the proliferation, migration, and adhesion of human ovarian cancer cells. Chin. Med. J. 124: 1327-32 [PMID:21740742]

688. Reppert SM, Weaver DR and Godson C. (1996) Melatonin receptors step into the light: cloning and classification of subtypes. Trends Pharmacol. Sci. 17: 100-2 [PMID:8936344]

689. Revankar CM, Cimino DF, Sklar LA, Arterburn JB and Prossnitz ER. (2005) A transmembrane intracellular estrogen receptor mediates rapid cell signaling. Science 307: 1625-30 [PMID:15705806]

690. Rezgaoui M, Süsens U, Ignatov A, Gelderblom M, Glassmeier G, Franke I, Urny J, Imai Y, Takahashi R and Schaller HC. (2006) The neuropeptide head activator is a high-affinity ligand for the orphan G-proteincoupled receptor GPR37. J. Cell. Sci. 119: 542-9 [PMID:16443751]

691. Riesewijk AM, Schepens MT, Mariman EM, Ropers HH and Kalscheuer VM. (1996) The MAS protooncogene is not imprinted in humans. Genomics 35: 380-2 [PMID:8661154] 
692. Riker Al, Enkemann SA, Fodstad O, Liu S, Ren S, Morris C, Xi Y, Howell P, Metge B, Samant RS, Shevde LA, Li W, Eschrich S, Daud A, Ju J and Matta J. (2008) The gene expression profiles of primary and metastatic melanoma yields a transition point of tumor progression and metastasis. BMC Med Genomics 1: 13 [PMID:18442402]

693. Rikitake Y, Hirata K, Yamashita T, Iwai K, Kobayashi S, Itoh H, Ozaki M, Ejiri J, Shiomi M and Inoue Net al.. (2002) Expression of G2A, a receptor for lysophosphatidylcholine, by macrophages in murine, rabbit, and human atherosclerotic plaques. Arterioscler. Thromb. Vasc. Biol. 22: 2049-53 [PMID:12482833]

694. Ritscher L, Engemaier E, Stäubert C, Liebscher I, Schmidt P, Hermsdorf T, Römpler H, Schulz A and Schöneberg T. (2012) The ligand specificity of the G-protein-coupled receptor GPR34. Biochem. J. 443: 841-50 [PMID:22348703]

695. Rivera SP, Saarikoski ST, Sun W and Hankinson O. (2007) Identification of novel dioxin-responsive genes by representational difference analysis. Xenobiotica 37: 271-9 [PMID:17624025]

696. Robas N, Mead E and Fidock M. (2003) MrgX2 is a high potency cortistatin receptor expressed in dorsal root ganglion. J. Biol. Chem. 278: 44400-4 [PMID:12915402]

697. Romero-Zerbo SY, Rafacho A, Díaz-Arteaga A, Suárez J, Quesada I, Imbernon M, Ross RA, Dieguez C, Rodríguez de Fonseca $F$ and Nogueiras $R$ et al.. (2011) A role for the putative cannabinoid receptor GPR55 in the islets of Langerhans. J. Endocrinol. 211: 177-85 [PMID:21885477]

698. Rosenkilde MM, Benned-Jensen T, Andersen H, Holst PJ, Kledal TN, Lüttichau HR, Larsen JK, Christensen JP and Schwartz TW. (2006) Molecular pharmacological phenotyping of EBI2. An orphan seven-transmembrane receptor with constitutive activity. J. Biol. Chem. 281: 13199-208 [PMID:16540462]

699. Ross PC, Figler RA, Corjay MH, Barber CM, Adam N, Harcus DR and Lynch KR. (1990) RTA, a candidate G protein-coupled receptor: cloning, sequencing, and tissue distribution. Proc. Natl. Acad. Sci. U.S.A.87: 3052-6 [PMID:2109324]

700. Ross RA. (2009) The enigmatic pharmacology of GPR55.Trends Pharmacol. Sci. 30: 156-63 [PMID:19233486]

701. Rossi P, Dolci S, Sette C, Capolunghi F, Pellegrini M, Loiarro M, Di Agostino S, Paronetto MP, Grimaldi P, Merico D, Martegani E and Geremia R. (2004) Analysis of the gene expression profile of mouse male meiotic germ cells. Gene Expr. Patterns 4: 267-81 [PMID:15053975]

702. Rosu-Myles M, Khandaker M, Wu DM, Keeney M, Foley SR, Howson-Jan K, Yee IC, Fellows F, Kelvin D and Bhatia M. (2000) Characterization of chemokine receptors expressed in primitive blood cells during human hematopoietic ontogeny. Stem Cells 18: 374-81 [PMID:11007922]

703. Roth RB, Hevezi P, Lee J, Willhite D, Lechner SM, Foster AC and Zlotnik A. (2006) Gene expression analyses reveal molecular relationships among 20 regions of the human CNS. Neurogenetics 7: 67-80 [PMID:16572319]

704. Rubic T, Lametschwandtner G, Jost S, Hinteregger S, Kund J, Carballido-Perrig N, Schwärzler C, Junt T, Voshol $\mathrm{H}$ and Meingassner JG et al.. (2008) Triggering the succinate receptor GPR91 on dendritic cells enhances immunity. Nat. Immunol. 9: 1261-9 [PMID:18820681]

705. Ruffner H, Sprunger J, Charlat O, Leighton-Davies J, Grosshans B, Salathe A, Zietzling S, Beck V, Therier $\mathrm{M}$ and Isken $\mathrm{A}$ et al.. (2012) R-Spondin potentiates Wnt/ $\beta$-catenin signaling through orphan receptors LGR4 and LGR5. PLOS ONE 7: e40976 [PMID:22815884]

706. Ruiz-Medina J, Ledent $C$ and Valverde O. (2011) GPR3 orphan receptor is involved in neuropathic pain after peripheral nerve injury and regulates morphine-induced antinociception. Neuropharmacology 61: 4350 [PMID:21352831]

707. Russell JL, Goetsch SC, Aguilar HR, Coe H, Luo X, Liu N, van Rooij E, Frantz DE and Schneider JW. (2012) Regulated expression of pH sensing G Protein-coupled receptor-68 identified through chemical biology defines a new drug target for ischemic heart disease. ACS Chem. Biol. 7: 1077-83 [PMID:22462679]

708. Ryan RR, Katsuno T, Mantey SA, Pradhan TK, Weber HC, Coy DH, Battey JF and Jensen RT. (1999) Comparative pharmacology of the nonpeptide neuromedin B receptor antagonist PD 168368. J. Pharmacol. Exp. Ther. 290: 1202-11 [PMID:10454496]

709. Ryan RR, Weber HC, Hou W, Sainz E, Mantey SA, Battey JF, Coy DH and Jensen RT. (1998) Ability of various bombesin receptor agonists and antagonists to alter intracellular signaling of the human orphan receptor BRS-3. J. Biol. Chem. 273: 13613-24 [PMID:9593699]

710. Ryan RR, Weber HC, Mantey SA, Hou W, Hilburger ME, Pradhan TK, Coy DH and Jensen RT. (1998) Pharmacology and intracellular signaling mechanisms of the native human orphan receptor BRS-3 in lung cancer cells. J. Pharmacol. Exp. Ther. 287: 366-80 [PMID:9765358]

711. Ryberg E, Larsson N, Sjögren S, Hjorth S, Hermansson NO, Leonova J, Elebring T, Nilsson K, Drmota T and Greasley PJ. (2007) The orphan receptor GPR55 is a novel cannabinoid receptor. Br. J. Pharmacol. 
152: 1092-101 [PMID:17876302]

712. Ryder C, McColl K, Zhong F and Distelhorst CW. (2012) Acidosis Promotes Bcl-2 Family-mediated Evasion of Apoptosis: INVOLVEMENT OF ACID-SENSING G PROTEIN-COUPLED RECEPTOR GPR65 SIGNALING TO MEK/ERK. J. Biol. Chem. 287: 27863-75 [PMID:22685289]

713. Römpler H, Schulz A, Pitra C, Coop G, Przeworski M, Pääbo S and Schöneberg T. (2005) The rise and fall of the chemoattractant receptor GPR33. J. Biol. Chem. 280: 31068-75 [PMID:15987686]

714. Römpler H, Yu HT, Arnold A, Orth A and Schöneberg T. (2006) Functional consequences of naturally occurring DRY motif variants in the mammalian chemoattractant receptor GPR33. Genomics 87: 724-32 [PMID:16595170]

715. Saeki $Y$, Ueno S, Mizuno R, Nishimura T, Fujimura H, Nagai $Y$ and Yanagihara T. (1993) Molecular cloning of a novel putative G protein-coupled receptor (GPCR21) which is expressed predominantly in mouse central nervous system. FEBS Lett. 336: 317-22 [PMID:8262253]

716. Sah R, Parker SL, Sheriff S, Eaton K, Balasubramaniam A and Sallee FR. (2007) Interaction of NPY compounds with the rat glucocorticoid-induced receptor (GIR) reveals similarity to the NPY-Y2 receptor. Peptides 28: $302-9$ [PMID:17240481]

717. Sah R, Pritchard LM, Richtand NM, Ahlbrand R, Eaton K, Sallee FR and Herman JP. (2005) Expression of the glucocorticoid-induced receptor mRNA in rat brain. Neuroscience 133: 281-92 [PMID:15893650]

718. Sakamoto Y, Inoue H, Kawakami S, Miyawaki K, Miyamoto T, Mizuta K and Itakura M. (2006) Expression and distribution of Gpr119 in the pancreatic islets of mice and rats: predominant localization in pancreatic polypeptide-secreting PP-cells. Biochem. Biophys. Res. Commun. 351: 474-80 [PMID:17070774]

719. Sampaio WO, Souza dos Santos RA, Faria-Silva R, da Mata Machado LT, Schiffrin EL and Touyz RM. (2007) Angiotensin-(1-7) through receptor Mas mediates endothelial nitric oxide synthase activation via Akt-dependent pathways. Hypertension 49: 185-92 [PMID:17116756]

720. Sancho V, Moody TW, Mantey SA, Di Florio A, Uehara H, Coy DH and Jensen RT. (2010) Pharmacology of putative selective hBRS-3 receptor agonists for human bombesin receptors (BnR): affinities, potencies and selectivity in multiple native and BnR transfected cells. Peptides 31: 1569-78 [PMID:20438784]

721. Sanderlin EJ, Leffler NR, Lertpiriyapong K, Cai Q, Hong H, Bakthavatchalu V, Fox JG, Oswald JZ, Justus CR and Krewson EA et al.. (2017) GPR4 deficiency alleviates intestinal inflammation in a mouse model of acute experimental colitis. Biochim Biophys Acta Mol Basis Dis 1863: 569-584 [PMID:27940273]

722. Sanders AR, Duan J, Levinson DF, Shi J, He D, Hou C, Burrell GJ, Rice JP, Nertney DA, Olincy A, Rozic P, Vinogradov S, Buccola NG, Mowry BJ, Freedman R, Amin F, Black DW, Silverman JM, Byerley WF, Crowe RR, Cloninger CR, Martinez M and Gejman PV. (2008) No significant association of 14 candidate genes with schizophrenia in a large European ancestry sample: implications for psychiatric genetics. $A m \mathrm{~J}$ Psychiatry 165: 497-506 [PMID:18198266]

723. Santos EL, Reis RI, Silva RG, Shimuta SI, Pecher C, Bascands JL, Schanstra JP, Oliveira L, Bader M and Paiva AC et al.. (2007) Functional rescue of a defective angiotensin II AT1 receptor mutant by the Mas protooncogene. Regul. Pept. 141: 159-67 [PMID:17320985]

724. Santos RA, Castro CH, Gava E, Pinheiro SV, Almeida AP, Paula RD, Cruz JS, Ramos AS, Rosa KT and Irigoyen MC et al.. (2006) Impairment of in vitro and in vivo heart function in angiotensin-(1-7) receptor MAS knockout mice. Hypertension 47: 996-1002 [PMID:16567589]

725. Santos RA, Haibara AS, Campagnole-Santos MJ, Simões e Silva AC, Paula RD, Pinheiro SV, Leite MF, Lemos VS, Silva DM and Guerra MT et al.. (2003) Characterization of a new selective antagonist for angiotensin-(1-7), D-pro7-angiotensin-(1-7). Hypertension 41: 737-43 [PMID:12623989]

726. Santos RA, Simoes e Silva AC, Maric C, Silva DM, Machado RP, de Buhr I, Heringer-Walther S, Pinheiro SV, Lopes MT and Bader M et al.. (2003) Angiotensin-(1-7) is an endogenous ligand for the G proteincoupled receptor Mas. Proc. Natl. Acad. Sci. U.S.A. 100: 8258-63 [PMID:12829792]

727. Santos SH, Fernandes LR, Mario EG, Ferreira AV, Pôrto LC, Alvarez-Leite JI, Botion LM, Bader M, Alenina N and Santos RA. (2008) Mas deficiency in FVB/N mice produces marked changes in lipid and glycemic metabolism. Diabetes 57: 340-7 [PMID:18025412]

728. Sauer CG, White K, Stöhr H, Grimm T, Hutchinson A, Bernstein PS, Lewis RA, Simonelli F, Pauleikhoff D, Allikmets $\mathrm{R}$ and Weber BH. (2001) Evaluation of the G protein coupled receptor-75 (GPR75) in age related macular degeneration. Br J Ophthalmo/85: 969-75 [PMID:11466257]

729. Savergnini SQ, Beiman M, Lautner RQ, de Paula-Carvalho V, Allahdadi K, Pessoa DC, Costa-Fraga FP, Fraga-Silva RA, Cojocaru $G$ and Cohen $Y$ et al.. (2010) Vascular relaxation, antihypertensive effect, and cardioprotection of a novel peptide agonist of the MAS receptor. Hypertension 56: 112-20 [PMID:20479330]

730. Sawzdargo M, George SR, Nguyen T, Xu S, Kolakowski LF and O'Dowd BF. (1997) A cluster of four novel human $\mathrm{G}$ protein-coupled receptor genes occurring in close proximity to CD22 gene on chromosome 
19q13.1. Biochem. Biophys. Res. Commun. 239: 543-7 [PMID:9344866]

731. Sawzdargo M, Nguyen T, Lee DK, Lynch KR, Cheng R, Heng HH, George SR and O'Dowd BF. (1999) Identification and cloning of three novel human $G$ protein-coupled receptor genes GPR52, PsiGPR53 and GPR55: GPR55 is extensively expressed in human brain. Brain Res. Mol. Brain Res. 64: 193-8 [PMID:9931487]

732. Saxena H, Deshpande DA, Tiegs BC, Yan H, Battafarano RJ, Burrows WM, Damera G, Panettieri RA, Dubose TD and An SS et al.. (2012) The GPCR OGR1 (GPR68) mediates diverse signalling and contraction of airway smooth muscle in response to small reductions in extracellular $\mathrm{pH}$. Br. J. Pharmacol. 166: 981-90 [PMID:22145625]

733. Schaub A, Fütterer A and Pfeffer K. (2001) PUMA-G, an IFN-gamma-inducible gene in macrophages is a novel member of the seven transmembrane spanning receptor superfamily. Eur. J. Immunol. 31: 3714-25 [PMID:11745392]

734. Schenten D, Marcon L, Karlsson GB, Parolin C, Kodama T, Gerard N and Sodroski J. (1999) Effects of soluble CD4 on simian immunodeficiency virus infection of CD4-positive and CD4-negative cells. J. Virol. 73: 5373-80 [PMID:10364284]

735. Schimenti JC. (1999) ORFless, intronless, and mutant transcription units in the mouse t complex responder (Tcr) locus. Mamm. Genome 10: 969-76 [PMID:10501965]

736. Schuelert $\mathrm{N}$ and McDougall JJ. (2011) The abnormal cannabidiol analogue O-1602 reduces nociception in a rat model of acute arthritis via the putative cannabinoid receptor GPR55. Neurosci. Lett. 500: 72-6 [PMID:21683763]

737. Schweifer N, Valk PJ, Delwel R, Cox R, Francis F, Meier-Ewert S, Lehrach H and Barlow DP. (1997) Characterization of the C3 YAC contig from proximal mouse chromosome 17 and analysis of allelic expression of genes flanking the imprinted Igf2r gene. Genomics 43: 285-97 [PMID:9268631]

738. Schöneberg T, Schulz A, Grosse R, Schade R, Henklein P, Schultz G and Gudermann T. (1999) A novel subgroup of class I G-protein-coupled receptors. Biochim. Biophys. Acta 1446: 57-70 [PMID:10395919]

739. Scott GA, Jacobs SE and Pentland AP. (2006) SPLA2-X stimulates cutaneous melanocyte dendricity and pigmentation through a lysophosphatidylcholine-dependent mechanism. J. Invest. Dermatol. 126: 855-61 [PMID:16456529]

740. Scott JS, Birch AM, Brocklehurst KJ, Broo A, Brown HS, Butlin RJ, Clarke DS, Davidsson O, Ertan A and Goldberg K et al.. (2012) Use of small-molecule crystal structures to address solubility in a novel series of $G$ protein coupled receptor 119 agonists: optimization of a lead and in vivo evaluation. J. Med. Chem. 55: 5361-79 [PMID:22545772]

741. Sebhat IK, Franklin C, Lo MM, Chen D, Jewell JP, Miller R, Pang J, Palyha O, Kan Y and Kelly TMet al.. (2011) Discovery of MK-5046, a Potent, Selective Bombesin Receptor Subtype-3 Agonist for the Treatment of Obesity. ACS Med Chem Lett 2: 43-7 [PMID:24900253]

742. Sellick GS, Coleman RJ, Webb EL, Chow J, Bevan S, Rosbotham JL and Houlston RS. (2005) Dominantly inherited cutaneous small-vessel lymphocytic vasculitis maps to chromosome 6q26-q27. Hum. Genet. 118: 82-6 [PMID:16133183]

743. Semple G, Fioravanti B, Pereira G, Calderon I, Uy J, Choi K, Xiong Y, Ren A, Morgan M and Dave Vet al.. (2008) Discovery of the first potent and orally efficacious agonist of the orphan G-protein coupled receptor 119. J. Med. Chem. 51: $5172-5$ [PMID:18698756]

744. Semple G, Lehmann J, Wong A, Ren A, Bruce M, Shin YJ, Sage CR, Morgan M, Chen WC and Sebring K et al.. (2012) Discovery of a second generation agonist of the orphan G-protein coupled receptor GPR119 with an improved profile. Bioorg. Med. Chem. Lett. 22: 1750-5 [PMID:22264481]

745. Semple G, Ren A, Fioravanti B, Pereira G, Calderon I, Choi K, Xiong Y, Shin YJ, Gharbaoui T and Sage $\mathrm{CR}$ et al.. (2011) Discovery of fused bicyclic agonists of the orphan G-protein coupled receptor GPR119 with in vivo activity in rodent models of glucose control. Bioorg. Med. Chem. Lett. 21: 3134-41 [PMID:21444206]

746. Serrano A, Rivera P, Pavon FJ, Decara J, Suárez J, Rodriguez de Fonseca F and Parsons LH. (2012) Differential effects of single versus repeated alcohol withdrawal on the expression of endocannabinoid system-related genes in the rat amygdala. Alcohol. Clin. Exp. Res. 36: 984-94 [PMID:22141465]

747. Serretti A, Pae CU, Chiesa A, Mandelli L and De Ronchi D. (2009) Influence of TAAR6 polymorphisms on response to aripiprazole. Prog. Neuropsychopharmacol. Biol. Psychiatry33: 822-6 [PMID:19345712]

748. Setoh M, Ishii N, Kono M, Miyanohana Y, Shiraishi E, Harasawa T, Ota H, Odani T, Kanzaki N and Aoyama $\mathrm{K}$ et al.. (2014) Discovery of the first potent and orally available agonist of the orphan G-proteincoupled receptor 52. J. Med. Chem. 57: 5226-37 [PMID:24884590]

749. Setty MK, Devadas K, Ragupathy V, Ravichandran V, Tang S, Wood O, Gaddam DS, Lee S and Hewlett IK. (2011) XMRV: usage of receptors and potential co-receptors. Virol. J. 8: 423 [PMID:21896167] 
750. Seuwen K, Ludwig MG and Wolf RM. (2006) Receptors for protons or lipid messengers or both?J. Recept. Signal Transduct. Res. 26: 599-610 [PMID:17118800]

751. Shaffer AL, Yu X, He Y, Boldrick J, Chan EP and Staudt LM. (2000) BCL-6 represses genes that function in lymphocyte differentiation, inflammation, and cell cycle control. Immunity 13: 199-212 [PMID:10981963]

752. Sharma R, Eng H, Walker GS, Barreiro G, Stepan AF, McClure KF, Wolford A, Bonin PD, Cornelius P and Kalgutkar AS. (2011) Oxidative metabolism of a quinoxaline derivative by xanthine oxidase in rodent plasma. Chem. Res. Toxicol. 24: 2207-16 [PMID:21939274]

753. Shemesh R, Toporik A, Levine Z, Hecht I, Rotman G, Wool A, Dahary D, Gofer E, Kliger Y and Soffer MA et al.. (2008) Discovery and validation of novel peptide agonists for G-protein-coupled receptors.J. Biol. Chem. 283: 34643-9 [PMID:18854305]

754. Shi F, Shen JK, Chen D, Fog K, Thirstrup K, Hentzer M, Karlsson JJ, Menon V, Jones KA and Smith KEet al.. (2011) Discovery and SAR of a Series of Agonists at Orphan G Protein-Coupled Receptor 139ACS Med Chem Lett 2: 303-6 [PMID:24900311]

755. Shields SD, Cavanaugh DJ, Lee H, Anderson DJ and Basbaum Al. (2010) Pain behavior in the formalin test persists after ablation of the great majority of C-fiber nociceptors. Pain 151: 422-9 [PMID:20832171]

756. Shinohara T, Harada M, Ogi K, Maruyama M, Fujii R, Tanaka H, Fukusumi S, Komatsu H, Hosoya M and Noguchi $Y$ et al.. (2004) Identification of a G protein-coupled receptor specifically responsive to betaalanine. J. Biol. Chem. 279: 23559-64 [PMID:15037633]

757. Shore DM and Reggio PH. (2015) The therapeutic potential of orphan GPCRs, GPR35 and GPR55.Front Pharmacol6: 69 [PMID:25926795]

758. Shyy W, Wang K, Gurnett CA, Dobbs MB, Miller NH, Wise C, Sheffield VC and Morcuende JA. (2010) Evaluation of GPR50, hMel-1B, and ROR-alpha melatonin-related receptors and the etiology of adolescent idiopathic scoliosis. J Pediatr Orthop 30: 539-43 [PMID:20733416]

759. Sidibe A, Mullier A, Chen P, Baroncini M, Boutin JA, Delagrange P, Prevot V and Jockers R. (2010) Expression of the orphan GPR50 protein in rodent and human dorsomedial hypothalamus, tanycytes and median eminence. J. Pineal Res. 48: 263-9 [PMID:20210849]

760. Sikand $P$, Dong $X$ and LaMotte RH. (2011) BAM8-22 peptide produces itch and nociceptive sensations in humans independent of histamine release. J. Neurosci. 31: 7563-7 [PMID:21593341]

761. Sin WC, Zhang Y, Zhong W, Adhikarakunnathu S, Powers S, Hoey T, An S and Yang J. (2004) G proteincoupled receptors GPR4 and TDAG8 are oncogenic and overexpressed in human cancers. Oncogene 23: 6299-303 [PMID:15221007]

762. Singh A, Besson G, Mobasher A and Collman RG. (1999) Patterns of chemokine receptor fusion cofactor utilization by human immunodeficiency virus type 1 variants from the lungs and blood. J. Virol. 73: 6680-90 [PMID:10400765]

763. Singh G and Davenport AP. (2006) Neuropeptide B and W: neurotransmitters in an emerging G-proteincoupled receptor system. Br. J. Pharmacol. 148: 1033-41 [PMID:16847439]

764. Slominski A, Pisarchik A, Zbytek B, Tobin DJ, Kauser S and Wortsman J. (2003) Functional activity of serotoninergic and melatoninergic systems expressed in the skin. J. Cell. Physiol. 196: 144-53 [PMID:12767050]

765. Snippert HJ, Haegebarth A, Kasper M, Jaks V, van Es JH, Barker N, van de Wetering M, van den Born M, Begthel H, Vries RG, Stange DE, Toftgård R and Clevers H. (2010) Lgr6 marks stem cells in the hair follicle that generate all cell lineages of the skin. Science 327: 1385-9 [PMID:20223988]

766. Soga T, Ohishi T, Matsui T, Saito T, Matsumoto M, Takasaki J, Matsumoto S, Kamohara M, Hiyama H and Yoshida $S$ et al.. (2005) Lysophosphatidylcholine enhances glucose-dependent insulin secretion via an orphan G-protein-coupled receptor. Biochem. Biophys. Res. Commun. 326: 744-51 [PMID:15607732]

767. Solinski HJ, Gudermann T and Breit A. (2014) Pharmacology and signaling of MAS-related G proteincoupled receptors. Pharmacol. Rev. 66: 570-97 [PMID:24867890]

768. Song H, Luo J, Luo W, Weng J, Wang Z, Li B, Li D and Liu M. (2008) Inactivation of G-protein-coupled receptor 48 (Gpr48/Lgr4) impairs definitive erythropoiesis at midgestation through down-regulation of the ATF4 signaling pathway. J. Biol. Chem. 283: 36687-97 [PMID:18955481]

769. Song ZH, Modi W and Bonner TI. (1995) Molecular cloning and chromosomal localization of human genes encoding three closely related $G$ protein-coupled receptors. Genomics 28: 347-9 [PMID:8530049]

770. Southern C, Cook JM, Neetoo-Isseljee Z, Taylor DL, Kettleborough CA, Merritt A, Bassoni DL, Raab WJ, Quinn E and Wehrman TS et al.. (2013) Screening $\beta$-Arrestin Recruitment for the Identification of Natural Ligands for Orphan G-Protein-Coupled Receptors. J Biomol Screen 18: 599-609 [PMID:23396314]

771. Sreedharan S, Almén MS, Carlini VP, Haitina T, Stephansson O, Sommer WH, Heilig M, de Barioglio SR, Fredriksson R and Schiöth HB. (2011) The G protein coupled receptor Gpr153 shares common evolutionary origin with Gpr162 and is highly expressed in central regions including the thalamus, 
cerebellum and the arcuate nucleus. FEBS J. 278: 4881-94 [PMID:21981325]

772. Staton PC, Hatcher JP, Walker DJ, Morrison AD, Shapland EM, Hughes JP, Chong E, Mander PK, Green PJ and Billinton A et al.. (2008) The putative cannabinoid receptor GPR55 plays a role in mechanical hyperalgesia associated with inflammatory and neuropathic pain. Pain 139: 225-36 [PMID:18502582]

773. Stein LM, Yosten GL and Samson WK. (2016) Adropin acts in brain to inhibit water drinking: potential interaction with the orphan G protein-coupled receptor, GPR19. Am. J. Physiol. Regul. Integr. Comp. Physiol. 310: R476-80 [PMID:26739651]

774. Stoddart LA, Smith NJ and Milligan G. (2008) International Union of Pharmacology. LXXI. Free fatty acid receptors FFA1, -2, and -3: pharmacology and pathophysiological functions. Pharmacol. Rev. 60: 405-17 [PMID:19047536]

775. Stone VM, Dhayal S, Smith DM, Lenaghan C, Brocklehurst KJ and Morgan NG. (2012) The cytoprotective effects of oleoylethanolamide in insulin-secreting cells do not require activation of GPR119. Br. J. Pharmacol. 165: 2758-70 [PMID:22029844]

776. Storjohann L, Holst B and Schwartz TW. (2008) Molecular mechanism of Zn2+ agonism in the extracellular domain of GPR39. FEBS Lett. 582: 2583-8 [PMID:18588883]

777. Storlazzi CT, Albano F, Lo Cunsolo C, Doglioni C, Guastadisegni MC, Impera L, Lonoce A, Funes S, Macrì E, luzzolino P, Panagopoulos I, Specchia G and Rocchi M. (2007) Upregulation of the SOX5 by promoter swapping with the P2RY8 gene in primary splenic follicular lymphoma. Leukemia 21: 2221-5 [PMID:17554380]

778. Stäubert C, Böselt I, Bohnekamp J, Römpler H, Enard W and Schöneberg T. (2010) Structural and functional evolution of the trace amine-associated receptors TAAR3, TAAR4 and TAAR5 in primates. PLOS ONE 5: e11133 [PMID:20559446]

779. Subramanian H, Gupta K and Ali H. (2016) Roles of Mas-related G protein-coupled receptor X2 on mast cell-mediated host defense, pseudoallergic drug reactions, and chronic inflammatory diseases. J. Allergy Clin. Immunol. 138: 700-10 [PMID:27448446]

780. Subramanian H, Gupta K, Guo Q, Price R and Ali H. (2011) Mas-related gene X2 (MrgX2) is a novel G protein-coupled receptor for the antimicrobial peptide LL-37 in human mast cells: resistance to receptor phosphorylation, desensitization, and internalization. J. Biol. Chem. 286: 44739-49 [PMID:22069323]

781. Subramanian H, Kashem SW, Collington SJ, Qu H, Lambris JD and Ali H. (2011) PMX-53 as a dual CD88 antagonist and an agonist for Mas-related gene 2 (MrgX2) in human mast cells. Mol. Pharmacol. 79: 100513 [PMID:21441599]

782. Sugimoto N, Oida T, Hirota K, Nakamura K, Nomura T, Uchiyama T and Sakaguchi S. (2006) Foxp3dependent and -independent molecules specific for CD25+CD4+ natural regulatory $T$ cells revealed by DNA microarray analysis. Int. Immunol. 18: 1197-209 [PMID:16772372]

783. Sugita K, Yamamura C, Tabata K and Fujita N. (2013) Expression of orphan G-protein coupled receptor GPR174 in $\mathrm{CHO}$ cells induced morphological changes and proliferation delay via increasing intracellular cAMP. Biochem. Biophys. Res. Commun. 430: 190-5 [PMID:23178570]

784. Sugo T and Mori M. (2008) Another ligand fishing for G protein-coupled receptor 14 . Discovery of urotensin II-related peptide in the rat brain. Peptides 29: 809-12 [PMID:17628210]

785. Sugo T, Tachimoto H, Chikatsu T, Murakami Y, Kikukawa Y, Sato S, Kikuchi K, Nagi T, Harada M, Ogi K, Ebisawa M and Mori M. (2006) Identification of a lysophosphatidylserine receptor on mast cells. Biochem. Biophys. Res. Commun. 341: 1078-87 [PMID:16460680]

786. Sumida H, Lu E, Chen H, Yang Q, Mackie K and Cyster JG. (2017) GPR55 regulates intraepithelial lymphocyte migration dynamics and susceptibility to intestinal damage. Sci Immuno/2: [PMID:29222090]

787. Sumida H, Noguchi K, Kihara Y, Abe M, Yanagida K, Hamano F, Sato S, Tamaki K, Morishita Y and Kano MR et al.. (2010) LPA4 regulates blood and lymphatic vessel formation during mouse embryogenesis. Blood 116: 5060-70 [PMID:20713964]

788. Sun X, Yang LV, Tiegs BC, Arend LJ, McGraw DW, Penn RB and Petrovic S. (2010) Deletion of the pH sensor GPR4 decreases renal acid excretion. J. Am. Soc. Nephrol.21: 1745-55 [PMID:20798260]

789. Suply T, Hannedouche S, Carte N, Li J, Grosshans B, Schaefer M, Raad L, Beck V, Vidal S and HiouFeige A et al.. (2017) A natural ligand for the orphan receptor GPR15 modulates lymphocyte recruitment to epithelia. Sci Signal10: [PMID:28900043]

790. Suzuki M, Takaishi S, Nagasaki M, Onozawa Y, lino I, Maeda H, Komai T and Oda T. (2013) Mediumchain Fatty Acid-sensing Receptor, GPR84, Is a Proinflammatory Receptor. J. Biol. Chem. 288: 10684-91 [PMID:23449982]

791. Swan C, Duroudier NP, Campbell E, Zaitoun A, Hastings M, Dukes GE, Cox J, Kelly FM, Wilde J and Lennon MG et al.. (2013) Identifying and testing candidate genetic polymorphisms in the irritable bowel syndrome (IBS): association with TNFSF15 and TNFa. Gut 62: 985-94 [PMID:22684480] 
792. Szewczyk JW, Acton J, Adams AD, Chicchi G, Freeman S, Howard AD, Huang Y, Li C, Meinke PT and Mosely R et al.. (2011) Design of potent and selective GPR119 agonists for type II diabetes.Bioorg. Med. Chem. Lett. 21: 2665-9 [PMID:21273063]

793. Süsens U, Hermans-Borgmeyer I, Urny J and Schaller HC. (2006) Characterisation and differential expression of two very closely related G-protein-coupled receptors, GPR139 and GPR142, in mouse tissue and during mouse development. Neuropharmacology 50: 512-20 [PMID:16378626]

794. Tabata K, Baba K, Shiraishi A, Ito M and Fujita N. (2007) The orphan GPCR GPR87 was deorphanized and shown to be a lysophosphatidic acid receptor. Biochem. Biophys. Res. Commun. 363: 861-6 [PMID:17905198]

795. Takeda S, Okada T, Okamura M, Haga T, Isoyama-Tanaka J, Kuwahara H and Minamino N. (2004) The receptor-Galpha fusion protein as a tool for ligand screening: a model study using a nociceptin receptorGalphai2 fusion protein. J. Biochem. 135: 597-604 [PMID:15173198]

796. Takenouchi R, Inoue K, Kambe $Y$ and Miyata A. (2012) N-arachidonoyl glycine induces macrophage apoptosis via GPR18. Biochem. Biophys. Res. Commun. 418: 366-71 [PMID:22266325]

797. Tallant EA, Ferrario CM and Gallagher PE. (2005) Angiotensin-(1-7) inhibits growth of cardiac myocytes through activation of the mas receptor. Am. J. Physiol. Heart Circ. Physiol.289: H1560-6 [PMID:15951342]

798. Tanaka S, Ishii K, Kasai K, Yoon SO and Saeki Y. (2007) Neural expression of G protein-coupled receptors GPR3, GPR6, and GPR12 up-regulates cyclic AMP levels and promotes neurite outgrowth. J. Biol. Chem. 282: 10506-15 [PMID:17284443]

799. Tanaka S, Shaikh IM, Chiocca EA and Saeki Y. (2009) The Gs-linked receptor GPR3 inhibits the proliferation of cerebellar granule cells during postnatal development. PLOS ONE 4: e5922 [PMID:19526062]

800. Taniguchi Y, Tonai-Kachi H and Shinjo K. (2006) Zaprinast, a well-known cyclic guanosine monophosphate-specific phosphodiesterase inhibitor, is an agonist for GPR35. FEBS Lett. 580: 5003-8 [PMID:16934253]

801. Tarttelin EE, Kirschner LS, Bellingham J, Baffi J, Taymans SE, Gregory-Evans K, Csaky K, Stratakis CA and Gregory-Evans CY. (1999) Cloning and characterization of a novel orphan G-protein-coupled receptor localized to human chromosome 2p16. Biochem. Biophys. Res. Commun. 260: 174-80 [PMID:10381362]

802. Tatemoto K, Nozaki Y, Tsuda R, Konno S, Tomura K, Furuno M, Ogasawara H, Edamura K, Takagi H and Iwamura $\mathrm{H}$ et al.. (2006) Immunoglobulin E-independent activation of mast cell is mediated by $\mathrm{Mrg}$ receptors. Biochem. Biophys. Res. Commun. 349: 1322-8 [PMID:16979137]

803. Thabuis C, Destaillats F, Landrier JF, Tissot-Favre D and Martin JC. (2010) Analysis of gene expression pattern reveals potential targets of dietary oleoylethanolamide in reducing body fat gain in $\mathrm{C} 3 \mathrm{H}$ mice. $\mathrm{J}$. Nutr. Biochem. 21: 922-8 [PMID:19954948]

804. Thathiah A, Spittaels K, Hoffmann M, Staes M, Cohen A, Horré K, Vanbrabant M, Coun F, Baekelandt V, Delacourte A, Fischer DF, Pollet D, De Strooper B and Merchiers P. (2009) The orphan G protein-coupled receptor 3 modulates amyloid-beta peptide generation in neurons. Science 323: 946-951 [PMID:19213921]

805. Thimm D, Funke M, Meyer A and Müller CE. (2013) 6-Bromo-8-(4-[(3)H]methoxybenzamido)-4-oxo-4Hchromene-2-carboxylic Acid: a powerful tool for studying orphan G protein-coupled receptor GPR35. J. Med. Chem. 56: 7084-99 [PMID:23888932]

806. Thomas P, Pang Y, Filardo EJ and Dong J. (2005) Identity of an estrogen membrane receptor coupled to a G protein in human breast cancer cells. Endocrinology 146: 624-32 [PMID:15539556]

807. Thomson PA, Wray NR, Thomson AM, Dunbar DR, Grassie MA, Condie A, Walker MT, Smith DJ, Pulford DJ, Muir W, Blackwood DH and Porteous DJ. (2005) Sex-specific association between bipolar affective disorder in women and GPR50, an X-linked orphan G protein-coupled receptor. Mol. Psychiatry 10: 470-8 [PMID:15452587]

808. Tobo A, Tobo M, Nakakura T, Ebara M, Tomura H, Mogi C, Im DS, Murata N, Kuwabara A and Ito Set al.. (2015) Characterization of Imidazopyridine Compounds as Negative Allosteric Modulators of ProtonSensing GPR4 in Extracellular Acidification-Induced Responses. PLOS ONE 10: e0129334 [PMID:26070068]

809. Tobo M, Tomura H, Mogi C, Wang JQ, Liu JP, Komachi M, Damirin A, Kimura T, Murata N, Kurose H, Sato $\mathrm{K}$ and Okajima F. (2007) Previously postulated "ligand-independent" signaling of GPR4 is mediated through proton-sensing mechanisms. Cell. Signal. 19: 1745-53 [PMID:17462861]

810. Toda N, Hao X, Ogawa Y, Oda K, Yu M, Fu Z, Chen Y, Kim Y, Lizarzaburu M and Lively Set al.. (2013) Potent and Orally Bioavailable GPR142 Agonists as Novel Insulin Secretagogues for the Treatment of Type 2 Diabetes. ACS Med Chem Lett 4: 790-4 [PMID:24900747]

811. Toma I, Kang JJ, Sipos A, Vargas S, Bansal E, Hanner F, Meer E and Peti-Peterdi J. (2008) Succinate receptor GPR91 provides a direct link between high glucose levels and renin release in murine and rabbit 
kidney. J. Clin. Invest. 118: 2526-34 [PMID:18535668]

812. Toms C, Jessup H, Thompson C, Baban D, Davies K and Powrie F. (2008) Gpr83 expression is not required for the maintenance of intestinal immune homeostasis and regulation of T-cell-dependent colitis. Immunology 125: 302-12 [PMID:18479351]

813. Tomura H, Mogi C, Sato K and Okajima F. (2005) Proton-sensing and lysolipid-sensitive G-protein-coupled receptors: a novel type of multi-functional receptors. Cell. Signal. 17: 1466-76 [PMID:16014326]

814. Tomura H, Wang JQ, Komachi M, Damirin A, Mogi C, Tobo M, Kon J, Misawa N, Sato K and Okajima F. (2005) Prostaglandin I(2) production and cAMP accumulation in response to acidic extracellular $\mathrm{pH}$ through OGR1 in human aortic smooth muscle cells. J. Biol. Chem. 280: 34458-64 [PMID:16087674]

815. Tomura H, Wang JQ, Liu JP, Komachi M, Damirin A, Mogi C, Tobo M, Nochi H, Tamoto K, Im DS, Sato K and Okajima F. (2008) Cyclooxygenase-2 expression and prostaglandin E2 production in response to acidic pH through OGR1 in a human osteoblastic cell line. J. Bone Miner. Res. 23: 1129-39 [PMID:18302504]

816. Toyooka M, Tujii T and Takeda S. (2009) The N-terminal domain of GPR61, an orphan G-protein-coupled receptor, is essential for its constitutive activity. J. Neurosci. Res. 87: 1329-33 [PMID:19025769]

817. Toyota M, Kopecky KJ, Toyota MO, Jair KW, Willman CL and Issa JP. (2001) Methylation profiling in acute myeloid leukemia. Blood 97: 2823-9 [PMID:11313277]

818. Tremblay F, Perreault M, Klaman LD, Tobin JF, Smith E and Gimeno RE. (2007) Normal food intake and body weight in mice lacking the G protein-coupled receptor GPR39. Endocrinology 148: 501-6 [PMID:17095592]

819. Trent JM, Thompson FH and Meyskens FL. (1989) Identification of a recurring translocation site involving chromosome 6 in human malignant melanoma. Cancer Res. 49: 420-3 [PMID:2642739]

820. Trivellin G, Daly AF, Faucz FR, Yuan B, Rostomyan L, Larco DO, Schernthaner-Reiter MH, Szarek E, Leal LF and Caberg JH et al.. (2014) Gigantism and acromegaly due to Xq26 microduplications and GPR101 mutation. N. Engl. J. Med. 371: 2363-74 [PMID:25470569]

821. Tyler WA, Jain MR, Cifelli SE, Li Q, Ku L, Feng Y, Li H and Wood TL. (2011) Proteomic identification of novel targets regulated by the mammalian target of rapamycin pathway during oligodendrocyte differentiation. Glia 59: 1754-69 [PMID:21858874]

822. Uehara H, González N, Sancho V, Mantey SA, Nuche-Berenguer B, Pradhan T, Coy DH and Jensen RT. (2011) Pharmacology and selectivity of various natural and synthetic bombesin related peptide agonists for human and rat bombesin receptors differs. Peptides 32: 1685-99 [PMID:21729729]

823. Uhlenbrock K, Gassenhuber H and Kostenis E. (2002) Sphingosine 1-phosphate is a ligand of the human gpr3, gpr6 and gpr12 family of constitutively active G protein-coupled receptors. Cell Signal 14: 941-953 [PMID:12220620]

824. Uhlenbrock K, Huber J, Ardati A, Busch AE and Kostenis E. (2003) Fluid shear stress differentially regulates gpr3, gpr6, and gpr12 expression in human umbilical vein endothelial cells. Cell. Physiol. Biochem. 13: 75-84 [PMID:12649592]

825. Underwood SL, Christoforou A, Thomson PA, Wray NR, Tenesa A, Whittaker J, Adams RA, Le Hellard S, Morris SW, Blackwood DH, Muir WJ, Porteous DJ and Evans KL. (2006) Association analysis of the chromosome 4p-located G protein-coupled receptor 78 (GPR78) gene in bipolar affective disorder and schizophrenia. Mol. Psychiatry 11: 384-94 [PMID:16389273]

826. Unutmaz D, KewalRamani VN and Littman DR. (1998) G protein-coupled receptors in HIV and SIV entry: new perspectives on lentivirus-host interactions and on the utility of animal models. Semin. Immunol. 10: 225-36 [PMID:9653049]

827. Valdenaire O, Giller T, Breu V, Ardati A, Schweizer A and Richards JG. (1998) A new family of orphan G protein-coupled receptors predominantly expressed in the brain. FEBS Lett. 424: 193-6 [PMID:9539149]

828. Valdes AM and Spector TD. (2010) The genetic epidemiology of osteoarthritis. Curr Opin Rheumato/22: 139-43 [PMID:20090528]

829. Valverde O, Célérier E, Baranyi M, Vanderhaeghen P, Maldonado R, Sperlagh B, Vassart G and Ledent C. (2009) GPR3 receptor, a novel actor in the emotional-like responses. PLoS ONE 4: e4704 [PMID:19259266]

830. van Hagen PM, Dalm VA, Staal F and Hofland LJ. (2008) The role of cortistatin in the human immune system. Mol. Cell. Endocrinol. 286: 141-7 [PMID:18450367]

831. Van Schoore G, Mendive F, Pochet R and Vassart G. (2005) Expression pattern of the orphan receptor LGR4/GPR48 gene in the mouse. Histochem. Cell Biol. 124: 35-50 [PMID:16028069]

832. Vanti WB, Muglia P, Nguyen T, Cheng R, Kennedy JL, George SR and O'Dowd BF. (2003) Discovery of a null mutation in a human trace amine receptor gene. Genomics 82: 531-536 [PMID:14559210]

833. Vanti WB, Nguyen T, Cheng R, Lynch KR, George SR and O'Dowd BF. (2003) Novel human G-protein- 
coupled receptors. Biochem. Biophys. Res. Commun. 305: 67-71 [PMID:12732197]

834. Vassilatis DK, Hohmann JG, Zeng H, Li F, Ranchalis JE, Mortrud MT, Brown A, Rodriguez SS, Weller JR and Wright AC et al.. (2003) The G protein-coupled receptor repertoires of human and mouse.Proc. Natl. Acad. Sci. U.S.A. 100: 4903-8 [PMID:12679517]

835. Velcicky J, Miltz W, Oberhauser B, Orain D, Vaupel A, Weigand K, Dawson King J, Littlewood-Evans A, Nash M and Feifel R et al.. (2017) Development of Selective, Orally Active GPR4 Antagonists with Modulatory Effects on Nociception, Inflammation, and Angiogenesis. J. Med. Chem. 60: 3672-3683 [PMID:28445047]

836. Venkataraman C and Kuo F. (2005) The G-protein coupled receptor, GPR84 regulates IL-4 production by T lymphocytes in response to CD3 crosslinking. Immunol. Lett. 101: 144-53 [PMID:15993493]

837. Vezzulli L, Guzmán CA, Colwell RR and Pruzzo C. (2008) Dual role colonization factors connecting Vibrio cholerae's lifestyles in human and aquatic environments open new perspectives for combating infectious diseases. Curr. Opin. Biotechnol. 19: 254-9 [PMID:18501582]

838. Villar AJ and Pedersen RA. (1994) Parental imprinting of the Mas protooncogene in mouse.Nat. Genet. 8: 373-9 [PMID:7894489]

839. Vladimirov VI, Maher BS, Wormley B, O'Neill FA, Walsh D, Kendler KS and Riley BP. (2009) The trace amine associated receptor (TAAR6) gene is not associated with schizophrenia in the Irish Case-Control Study of Schizophrenia (ICCSS) sample. Schizophr. Res. 107: 249-54 [PMID:18973992]

840. Von Bohlen und Halbach O, Walther T, Bader M and Albrecht D. (2000) Interaction between Mas and the angiotensin AT1 receptor in the amygdala. J. Neurophysiol. 83: 2012-21 [PMID:10758111]

841. Vödrös D and Fenyö EM. (2005) Quantitative evaluation of HIV and SIV co-receptor use with GHOST(3) cell assay. Methods Mol. Biol. 304: 333-42 [PMID:16061987]

842. Vödrös D, Thorstensson R, Biberfeld G, Schols D, De Clercq E and Fenyö EM. (2001) Coreceptor usage of sequential isolates from cynomolgus monkeys experimentally Infected with simian immunodeficiency virus (SIVsm). Virology 291: 12-21 [PMID:11878872]

843. Vödrös D, Thorstensson R, Doms RW, Fenyö EM and Reeves JD. (2003) Evolution of coreceptor use and CD4-independence in envelope clones derived from SIVsm-infected macaques. Virology 316: 17-28 [PMID:14599787]

844. Waldeck-Weiermair M, Zoratti C, Osibow K, Balenga N, Goessnitzer E, Waldhoer M, Malli R and Graier WF. (2008) Integrin clustering enables anandamide-induced Ca2+ signaling in endothelial cells via GPR55 by protection against CB1-receptor-triggered repression. J. Cell. Sci. 121: 1704-17 [PMID:18445684]

845. Wallrabenstein I, Kuklan J, Weber L, Zborala S, Werner M, Altmüller J, Becker C, Schmidt A, Hatt H and Hummel T et al.. (2013) Human trace amine-associated receptor TAAR5 can be activated by trimethylamine. PLOS ONE 8: e54950 [PMID:23393561]

846. Walther T, Balschun D, Voigt JP, Fink H, Zuschratter W, Birchmeier C, Ganten D and Bader M. (1998) Sustained long term potentiation and anxiety in mice lacking the Mas protooncogene. J. Biol. Chem. 273: 11867-73 [PMID:9565612]

847. Walther T, Wessel N, Kang N, Sander A, Tschöpe C, Malberg H, Bader M and Voss A. (2000) Altered heart rate and blood pressure variability in mice lacking the Mas protooncogene. Braz. J. Med. Biol. Res. 33: 1-9 [PMID:10625868]

848. Wan ES, Qiu W, Baccarelli A, Carey VJ, Bacherman H, Rennard SI, Agusti A, Anderson W, Lomas DA and Demeo DL. (2012) Cigarette smoking behaviors and time since quitting are associated with differential DNA methylation across the human genome. Hum. Mol. Genet. 21: 3073-82 [PMID:22492999]

849. Wang C, Dehghani B, Magrisso IJ, Rick EA, Bonhomme E, Cody DB, Elenich LA, Subramanian S, Murphy SJ and Kelly MJ et al.. (2008) GPR30 contributes to estrogen-induced thymic atrophy.Mol. Endocrinol. 22: 636-48 [PMID:18063692]

850. Wang D, Herman JP, Pritchard LM, Spitzer RH, Ahlbrand RL, Kramer GL, Petty F, Sallee FR and Richtand NM. (2001) Cloning, expression, and regulation of a glucocorticoid-induced receptor in rat brain: effect of repetitive amphetamine. J. Neurosci. 21: 9027-35 [PMID:11698613]

851. Wang D, Huang B, Zhang S, Yu X, Wu W and Wang X. (2013) Structural basis for R-spondin recognition by LGR4/5/6 receptors. Genes Dev. 27: 1339-44 [PMID:23756652]

852. Wang D, Stoveken HM, Zucca S, Dao M, Orlandi C, Song C, Masuho I, Johnston C, Opperman KJ and Giles AC et al.. (2019) Genetic behavioral screen identifies an orphan anti-opioid system. Science 365: 1267-1273 [PMID:31416932]

853. Wang $\mathrm{H}$ and Zylka MJ. (2009) Mrgprd-expressing polymodal nociceptive neurons innervate most known classes of substantia gelatinosa neurons. J. Neurosci. 29: 13202-9 [PMID:19846708]

854. Wang HQ, Imai Y, Inoue H, Kataoka A, lita S, Nukina N and Takahashi R. (2008) Pael-R transgenic mice crossed with parkin deficient mice displayed progressive and selective catecholaminergic neuronal loss. $J$. 
Neurochem. 107: 171-85 [PMID:18691389]

855. Wang J, Duhart HM, Xu Z, Patterson TA, Newport GD and Ali SF. (2008) Comparison of the time courses of selective gene expression and dopaminergic depletion induced by MPP+ in MN9D cells. Neurochem. Int. 52: 1037-43 [PMID:18069091]

856. Wang J, Li X, Ke Y, Lu Y, Wang F, Fan N, Sun H, Zhang H, Liu R and Yang tet al.. (2012) GPR48 increases mineralocorticoid receptor gene expression. J. Am. Soc. Nephrol.23: 281-93 [PMID:22135314]

857. Wang J, Simonavicius N, Wu X, Swaminath G, Reagan J, Tian H and Ling L. (2006) Kynurenic acid as a ligand for orphan G protein-coupled receptor GPR35. J. Biol. Chem. 281: 22021-8 [PMID:16754668]

858. Wang J, Wu X, Simonavicius N, Tian H and Ling L. (2006) Medium-chain fatty acids as ligands for orphan G protein-coupled receptor GPR84. J. Biol. Chem. 281: 34457-64 [PMID:16966319]

859. Wang J, Zhu LY, Liu Q, Hentzer M, Smith GP and Wang MW. (2015) High-throughput screening of antagonists for the orphan G-protein coupled receptor GPR139. Acta Pharmacol. Sin. 36: 874-8 [PMID:26027661]

860. Wang JQ, Kon J, Mogi C, Tobo M, Damirin A, Sato K, Komachi M, Malchinkhuu E, Murata N, Kimura T, Kuwabara A, Wakamatsu K, Koizumi H, Uede T, Tsujimoto G, Kurose H, Sato T, Harada A, Misawa N, Tomura $\mathrm{H}$ and Okajima F. (2004) TDAG8 is a proton-sensing and psychosine-sensitive G-protein-coupled receptor. J. Biol. Chem. 279: 45626-33 [PMID:15326175]

861. Wang Y, de Vallière C, Imenez Silva PH, Leonardi I, Gruber S, Gerstgrasser A, Melhem H, Weber A, Leucht K and Wolfram L et al.. (2018) The Proton-activated Receptor GPR4 Modulates Intestinal Inflammation. J Crohns Colitis 12: 355-368 [PMID:29136128]

862. Wang Y, Pringle KG, Sykes SD, Marques FZ, Morris BJ, Zakar T and Lumbers ER. (2012) Fetal sex affects expression of renin-angiotensin system components in term human decidua. Endocrinology 153: 462-8 [PMID:22045662]

863. Wang Y, Zhang M, Tan Y, Xiang Y, Liu H, Qu F, Qin L and Qin X. (2007) BRS-3 activation transforms the effect of human bronchial epithelial cells from PGE2 mediated inhibition to TGF-beta1 dependent promotion on proliferation and collagen synthesis of lung fibroblasts. Cell Biol. Int. 31: 1495-500 [PMID:17714959]

864. Wang Z, Jin C, Li H, Li C, Hou Q, Liu M, Dong Xda E and Tu L. (2010) GPR48-Induced keratinocyte proliferation occurs through HB-EGF mediated EGFR transactivation. FEBS Lett. 584: 4057-62 [PMID:20732323]

865. Weber D, Berger C, Eickelmann P, Antel J and Kessler H. (2003) Design of selective peptidomimetic agonists for the human orphan receptor BRS-3. J. Med. Chem. 46: 1918-30 [PMID:12723954]

866. Weber D, Berger C, Heinrich T, Eickelmann P, Antel J and Kessler H. (2002) Systematic optimization of a lead-structure identities for a selective short peptide agonist for the human orphan receptor BRS-3. J. Pept. Sci. 8: 461-75 [PMID:12212809]

867. Weber HC, Jensen RT and Battey JF. (2000) Molecular organization of the mouse gastrin-releasing peptide receptor gene and its promoter. Gene 244: 137-49 [PMID:10689196]

868. Weber HC, Walters J, Leyton J, Casibang M, Purdom S, Jensen RT, Coy DH, Ellis C, Clark G and Moody TW. (2001) A bombesin receptor subtype-3 peptide increases nuclear oncogene expression in a MEK-1 dependent manner in human lung cancer cells. Eur. J. Pharmacol. 412: 13-20 [PMID:11166731]

869. Wei X, Walia V, Lin JC, Teer JK, Prickett TD, Gartner J, Davis S, NISC Comparative Sequencing Program, Stemke-Hale K and Davies MA et al.. (2011) Exome sequencing identifies GRIN2A as frequently mutated in melanoma. Nat. Genet. 43: 442-6 [PMID:21499247]

870. Weiler A, May GE, Qi Y, Wilson N and Watkins DI. (2006) Polymorphisms in eight host genes associated with control of HIV replication do not mediate elite control of viral replication in SIV-infected Indian rhesus macaques. Immunogenetics 58: 1003-9 [PMID:17106666]

871. Weng J, Luo J, Cheng X, Jin C, Zhou X, Qu J, Tu L, Ai D, Li D, Wang J, Martin JF, Amendt BA and Liu M. (2008) Deletion of $G$ protein-coupled receptor 48 leads to ocular anterior segment dysgenesis (ASD) through down-regulation of Pitx2. Proc. Natl. Acad. Sci. U.S.A. 105: 6081-6 [PMID:18424556]

872. Weng Z, Fluckiger AC, Nisitani S, Wahl MI, Le LQ, Hunter CA, Fernal AA, Le Beau MM and Witte ON. (1998) A DNA damage and stress inducible G protein-coupled receptor blocks cells in G2/M. Proc. Natl. Acad. Sci. U.S.A. 95: 12334-9 [PMID:9770487]

873. Whalley NM, Pritchard LE, Smith DM and White A. (2011) Processing of proglucagon to GLP-1 in pancreatic $\alpha$-cells: is this a paracrine mechanism enabling GLP-1 to act on $\beta$-cells? J. Endocrinol. 211: 99106 [PMID:21795304]

874. Whyte LS, Ryberg E, Sims NA, Ridge SA, Mackie K, Greasley PJ, Ross RA and Rogers MJ. (2009) The putative cannabinoid receptor GPR55 affects osteoclast function in vitro and bone mass in vivo. Proc. Natl. Acad. Sci. U.S.A. 106: 16511-6 [PMID:19805329] 
875. Wiemer G, Dobrucki LW, Louka FR, Malinski T and Heitsch H. (2002) AVE 0991, a nonpeptide mimic of the effects of angiotensin-(1-7) on the endothelium. Hypertension 40: 847-52 [PMID:12468568]

876. Williams JR, Khandoga AL, Goyal P, Fells JI, Perygin DH, Siess W, Parrill AL, Tigyi G and Fujiwara Y. (2009) Unique ligand selectivity of the GPR92/LPA5 lysophosphatidate receptor indicates role in human platelet activation. J. Biol. Chem. 284: 17304-19 [PMID:19366702]

877. Wilson SR, Gerhold KA, Bifolck-Fisher A, Liu Q, Patel KN, Dong X and Bautista DM. (2011) TRPA1 is required for histamine-independent, Mas-related G protein-coupled receptor-mediated itch. Nat. Neurosci. 14: 595-602 [PMID:21460831]

878. Witte ON, Kabarowski JH, Xu Y, Le LQ and Zhu K. (2005) Retraction.Science 307: 206 [PMID:15653487]

879. Wittenberger T, Schaller HC and Hellebrand S. (2001) An expressed sequence tag (EST) data mining strategy succeeding in the discovery of new G-protein coupled receptors. J. Mol. Biol. 307: 799-813 [PMID:11273702]

880. Wu Y, Kuntz JD, Carpenter AJ, Fang J, Sauls HR, Gomez DJ, Ammala C, Xu Y, Hart S and Tadepalli S. (2010) 2,5-Disubstituted pyridines as potent GPR119 agonists. Bioorg. Med. Chem. Lett. 20: 2577-81 [PMID:20227877]

881. Wunder F, Tinel H, Kast R, Geerts A, Becker EM, Kolkhof P, Hütter J, Ergüden J and Härter M. (2010) Pharmacological characterization of the first potent and selective antagonist at the cysteinyl leukotriene 2 (CysLT(2)) receptor. Br. J. Pharmacol. 160: 399-409 [PMID:20423349]

882. Wyder L, Suply T, Ricoux B, Billy E, Schnell C, Baumgarten BU, Maira SM, Koelbing C, Ferretti M and Kinzel $B$ et al.. (2011) Reduced pathological angiogenesis and tumor growth in mice lacking GPR4, a proton sensing receptor. Angiogenesis 14: 533-44 [PMID:22045552]

883. Xi L, Junjian Z, Yumin L, Yunwen L and Hongbin W. (2009) Serum biomarkers of vascular cognitive impairment evaluated by bead-based proteomic technology. Neurosci. Lett. 463: 6-11 [PMID:19631719]

884. Xia Y, Chackalamannil S, Greenlee WJ, Jayne C, Neustadt B, Stamford A, Vaccaro H, Xu XL, Baker H and O'Neill K et al.. (2011) Discovery of a nortropanol derivative as a potent and orally active GPR119 agonist for type 2 diabetes. Bioorg. Med. Chem. Lett. 21: 3290-6 [PMID:21536438]

885. Xiao L, Rudolph DL, Owen SM, Spira TJ and Lal RB. (1998) Adaptation to promiscuous usage of CC and CXC-chemokine coreceptors in vivo correlates with HIV-1 disease progression. AIDS 12: F137-43 [PMID:9764773]

886. Xiao XQ, Grove KL, Lau SY, McWeeney S and Smith MS. (2005) Deoxyribonucleic acid microarray analysis of gene expression pattern in the arcuate nucleus/ventromedial nucleus of hypothalamus during lactation. Endocrinology 146: 4391-8 [PMID:16002521]

887. Xu P, Costa-Goncalves AC, Todiras M, Rabelo LA, Sampaio WO, Moura MM, Santos SS, Luft FC, Bader $M$ and Gross $V$ et al.. (2008) Endothelial dysfunction and elevated blood pressure in MAS gene-deleted mice. Hypertension 51: 574-80 [PMID:18180400]

888. Xu P, Santos RA, Bader M and Alenina N. (2007) Alterations in gene expression in the testis of angiotensin-(1-7)-receptor Mas-deficient mice. Regul. Pept. 138: 51-5 [PMID:17196677]

889. Xu X, Quiambao AB, Roveri L, Pardue MT, Marx JL, Röhlich P, Peachey NS and Al-Ubaidi MR. (2000) Degeneration of cone photoreceptors induced by expression of the Mas1 protooncogene. Exp. Neurol. 163: 207-19 [PMID:10785460]

890. Xu Y. (2002) Sphingosylphosphorylcholine and lysophosphatidylcholine: G protein-coupled receptors and receptor-mediated signal transduction. Biochim. Biophys. Acta 1582: 81-8 [PMID:12069813]

891. Xu Y and Casey G. (1996) Identification of human OGR1, a novel G protein-coupled receptor that maps to chromosome 14. Genomics 35: 397-402 [PMID:8661159]

892. Xu Y, Zhu K, Hong G, Wu W, Baudhuin LM, Xiao Y and Damron DS. (2000) Sphingosylphosphorylcholine is a ligand for ovarian cancer G-protein-coupled receptor 1. Nat. Cell Biol. 2: 261-7 [PMID:10806476]

893. Yamashita A, Kumazawa T, Koga H, Suzuki N, Oka S and Sugiura T. (2010) Generation of lysophosphatidylinositol by DDHD domain containing 1 (DDHD1): Possible involvement of phospholipase D/phosphatidic acid in the activation of DDHD1. Biochim. Biophys. Acta 1801: 711-20 [PMID:20359546]

894. Yamashita R, Takegawa Y, Sakumoto M, Nakahara M, Kawazu H, Hoshii T, Araki K, Yokouchi Y and Yamamura K. (2009) Defective development of the gall bladder and cystic duct in Lgr4- hypomorphic mice. Dev. Dyn. 238: 993-1000 [PMID:19301403]

895. Yanagida K, Masago K, Nakanishi H, Kihara Y, Hamano F, Tajima Y, Taguchi R, Shimizu T and Ishii S. (2009) Identification and characterization of a novel lysophosphatidic acid receptor, p2y5/LPA6. J. Biol. Chem. 284: 17731-41 [PMID:19386608]

896. Yang C, Yang Q and Compans RW. (2000) Coreceptor-dependent inhibition of the cell fusion activity of simian immunodeficiency virus Env proteins. J. Virol. 74: 6217-22 [PMID:10846110]

897. Yang LV, Radu CG, Roy M, Lee S, McLaughlin J, Teitell MA, Iruela-Arispe ML and Witte ON. (2007) 
Vascular abnormalities in mice deficient for the G protein-coupled receptor GPR4 that functions as a pH sensor. Mol. Cell. Biol. 27: 1334-47 [PMID:17145776]

898. Yang LV, Radu CG, Wang L, Riedinger M and Witte ON. (2005) Gi-independent macrophage chemotaxis to lysophosphatidylcholine via the immunoregulatory GPCR G2A. Blood 105: 1127-34 [PMID:15383458]

899. Yang M, Mailhot G, Birnbaum MJ, MacKay CA, Mason-Savas A and Odgren PR. (2006) Expression of and role for ovarian cancer G-protein-coupled receptor 1 (OGR1) during osteoclastogenesis. J. Biol. Chem. 281: 23598-605 [PMID:16787916]

900. Yang Y, Fu A, Wu X and Reagan JD. (2012) GPR35 is a target of the loop diuretic drugs bumetanide and furosemide. Pharmacology 89: 13-7 [PMID:22236570]

901. Yasuda H, Hirata S, Inoue K, Mashima H, Ohnishi H and Yoshiba M. (2007) Involvement of membranetype bile acid receptor M-BAR/TGR5 in bile acid-induced activation of epidermal growth factor receptor and mitogen-activated protein kinases in gastric carcinoma cells. Biochem. Biophys. Res. Commun. 354: 154-9 [PMID:17214962]

902. Yasuda S, Miyazaki T, Munechika K, Yamashita M, Ikeda Y and Kamizono A. (2007) Isolation of Zn2+ as an endogenous agonist of GPR39 from fetal bovine serum. J. Recept. Signal Transduct. Res. 27: 235-46 [PMID:17885920]

903. Ye C, Zhang Z, Wang Z, Hua Q, Zhang R and Xie X. (2014) Identification of a novel small-molecule agonist for human G protein-coupled receptor 3. J. Pharmacol. Exp. Ther. 349: 437-43 [PMID:24633425]

904. Yee KK, Li Y, Redding KM, Iwatsuki K, Margolskee RF and Jiang P. (2013) Lgr5-EGFP marks taste bud stem/progenitor cells in posterior tongue. Stem Cells 31: 992-1000 [PMID:23377989]

905. Yin H, Chu A, Li W, Wang B, Shelton F, Otero F, Nguyen DG, Caldwell JS and Chen YA. (2009) Lipid G protein-coupled receptor ligand identification using beta-arrestin PathHunter assay. J Biol Chem 284: 12328-12338 [PMID:19286662]

906. Yoshida S, Ohishi T, Matsui T and Shibasaki M. (2010) Identification of a novel GPR119 agonist, AS1269574, with in vitro and in vivo glucose-stimulated insulin secretion. Biochem. Biophys. Res. Commun. 400: 437-41 [PMID:20804735]

907. Yoshida S, Ohishi T, Matsui T, Tanaka H, Oshima H, Yonetoku Y and Shibasaki M. (2010) Novel GPR119 agonist AS1535907 contributes to first-phase insulin secretion in rat perfused pancreas and diabetic $\mathrm{db} / \mathrm{db}$ mice. Biochem. Biophys. Res. Commun. 402: 280-5 [PMID:20937249]

908. Yoshida S, Ohishi T, Matsui T, Tanaka H, Oshima H, Yonetoku Y and Shibasaki M. (2011) The role of small molecule GPR119 agonist, AS1535907, in glucose-stimulated insulin secretion and pancreatic $\beta$-cell function. Diabetes Obes Metab 13: 34-41 [PMID:21114601]

909. Yoshida S, Tanaka H, Oshima H, Yamazaki T, Yonetoku Y, Ohishi T, Matsui T and Shibasaki M. (2010) AS1907417, a novel GPR119 agonist, as an insulinotropic and $\beta$-cell preservative agent for the treatment of type 2 diabetes. Biochem. Biophys. Res. Commun. 400: 745-51 [PMID:20816753]

910. Yosten GL, Kolar GR, Redlinger LJ and Samson WK. (2013) Evidence for an interaction between proinsulin C-peptide and GPR146. J. Endocrinol. 218: B1-8 [PMID:23759446]

911. Yotsumoto S, Shimada T, Cui CY, Nakashima H, Fujiwara H and Ko MS. (1998) Expression of adrenomedullin, a hypotensive peptide, in the trophoblast giant cells at the embryo implantation site in mouse. Dev. Biol. 203: 264-75 [PMID:9808778]

912. Young D, O'Neill K, Jessell T and Wigler M. (1988) Characterization of the rat mas oncogene and its highlevel expression in the hippocampus and cerebral cortex of rat brain. Proc. Natl. Acad. Sci. U.S.A.85: 5339-42 [PMID:2455902]

913. Young D, Waitches G, Birchmeier C, Fasano O and Wigler M. (1986) Isolation and characterization of a new cellular oncogene encoding a protein with multiple potential transmembrane domains. Cell 45: 711-9 [PMID:3708691]

914. Yousefi S, Cooper PR, Potter SL, Mueck B and Jarai G. (2001) Cloning and expression analysis of a novel G-protein-coupled receptor selectively expressed on granulocytes. J. Leukoc. Biol. 69: 1045-52 [PMID:11404393]

915. Yu M, Lizarzaburu M, Motani A, Fu Z, Du X, Liu JJ, Jiao X, Lai S, Fan P and Fu Aet al.. (2013) Aminopyrazole-Phenylalanine Based GPR142 Agonists: Discovery of Tool Compound and in Vivo Efficacy Studies. ACS Med Chem Lett 4: 829-34 [PMID:24900757]

916. Yu X, Huang XP, Kenakin TP, Slocum ST, Chen X, Martini ML, Liu J and Jin J. (2019) Design, Synthesis, and Characterization of Ogerin-Based Positive Allosteric Modulators for G Protein-Coupled Receptor 68 (GPR68). J. Med. Chem. 62: 7557-7574 [PMID:31298539]

917. Zabel BA, Silverio AM and Butcher EC. (2005) Chemokine-like receptor 1 expression and chemerindirected chemotaxis distinguish plasmacytoid from myeloid dendritic cells in human blood. J. Immunol. 174: 244-51 [PMID:15611246] 
918. Zaslavsky A, Singh LS, Tan H, Ding H, Liang Z and Xu Y. (2006) Homo- and hetero-dimerization of LPA/S1P receptors, OGR1 and GPR4. Biochim. Biophys. Acta 1761: 1200-12 [PMID:17023202]

919. Zeng Z, Fan P, Rand E, Kyaw H, Su K, Madike V, Carter KC and Li Y. (1998) Cloning of a putative human neurotransmitter receptor expressed in skeletal muscle and brain. Biochem. Biophys. Res. Commun. 242: 575-8 [PMID:9464258]

920. Zeng Z, Su K, Kyaw H and Li Y. (1997) A novel endothelin receptor type-B-like gene enriched in the brain. Biochem. Biophys. Res. Commun. 233: 559-67 [PMID:9144577]

921. Zhang JC, Xie YF, Liu SJ, Dai LB and Li JP. (2010) [The expression of melatonin receptor in human hypertrophic scar]. Zhonghua Zheng Xing Wai Ke Za Zhi26: 203-7 [PMID:20737950]

922. Zhang JV, Klein C, Ren P, Kass S, Ver Donck L, Moechars D and Hsueh AJW. (2007) Response to Comment on "Obestatin, a Peptide Encoded by the Ghrelin Gene, Opposes Ghrelin's Effects on Food Intake". Science 315: 766d

923. Zhang JV, Ren PG, Avsian-Kretchmer O, Luo CW, Rauch R, Klein C and Hsueh AJ. (2005) Obestatin, a peptide encoded by the ghrelin gene, opposes ghrelin's effects on food intake. Science 310: 996-9 [PMID:16284174]

924. Zhang L, He T, Huang Y, Chen Z, Guo Y, Wu S, Kunstman KJ, Brown RC, Phair JP and Neumann Alet al.. (1998) Chemokine coreceptor usage by diverse primary isolates of human immunodeficiency virus type 1. J. Virol. 72: 9307-12 [PMID:9765480]

925. Zhang L, Nothacker HP, Wang Z, Bohn LM and Civelli O. (2009) Pharmacological characterization of a selective agonist for bombesin receptor subtype-3. Biochem. Biophys. Res. Commun. 387: 283-8 [PMID:19580790]

926. Zhang L, Parks GS, Wang Z, Wang L, Lew M and Civelli O. (2013) Anatomical characterization of bombesin receptor subtype-3 mRNA expression in the rodent central nervous system. J. Comp. Neurol. 521: 1020-39 [PMID:22911445]

927. Zhang L, Taylor N, Xie Y, Ford R, Johnson J, Paulsen JE and Bates B. (2005) Cloning and expression of MRG receptors in macaque, mouse, and human. Brain Res. Mol. Brain Res. 133: 187-97 [PMID:15710235]

928. Zhang LL, Wang JJ, Liu Y, Lu XB, Kuang Y, Wan YH, Chen Y, Yan HM, Fei J and Wang ZG. (2011) GPR26-deficient mice display increased anxiety- and depression-like behaviors accompanied by reduced phosphorylated cyclic AMP responsive element-binding protein level in central amygdala. Neuroscience 196: 203-14 [PMID:21924326]

929. Zhang LY, Jia MR and Sun T. (2018) The roles of special proresolving mediators in pain reliefRev Neurosci 29: 645-660 [PMID:29420307]

930. Zhang M and Xia G. (2012) Hormonal control of mammalian oocyte meiosis at diplotene stage.Cell. Mol. Life Sci. 69: 1279-88 [PMID:22045555]

931. Zhang T, Li Z, Dang H, Chen R, Liaw C, Tran TA, Boatman PD, Connolly DT and Adams JW. (2012) Inhibition of Mas G-protein signaling improves coronary blood flow, reduces myocardial infarct size, and provides long-term cardioprotection. Am. J. Physiol. Heart Circ. Physiol.302: H299-311 [PMID:22003054]

932. Zhang X, Maor Y, Wang JF, Kunos G and Groopman JE. (2010) Endocannabinoid-like N-arachidonoyl serine is a novel pro-angiogenic mediator. Br. J. Pharmacol. 160: 1583-94 [PMID:20649563]

933. Zhao B, Zhao CZ, Zhang XY, Huang XQ, Shi WZ, Fang SH, Lu YB, Zhang WP, Xia Q and Wei EQ. (2012) The new P2Y-like receptor $G$ protein-coupled receptor 17 mediates acute neuronal injury and late microgliosis after focal cerebral ischemia in rats. Neuroscience 202: 42-57 [PMID:22155652]

934. Zhao P, Sharir H, Kapur A, Cowan A, Geller EB, Adler MW, Seltzman HH, Reggio PH, Heynen-Genel S, Sauer M, Chung TD, Bai Y, Chen W, Caron MG, Barak LS and Abood ME. (2010) Targeting of the orphan receptor GPR35 by pamoic acid: a potent activator of extracellular signal-regulated kinase and $\beta$-arrestin2 with antinociceptive activity. Mol. Pharmacol. 78: 560-8 [PMID:20826425]

935. Zhao SX, Xue LQ, Liu W, Gu ZH, Pan CM, Yang SY, Zhan M, Wang HN, Liang J and Gao Gœet al.. (2013) Robust evidence for five new Graves' disease risk loci from a staged genome-wide association analysis. Hum. Mol. Genet. 22: 3347-62 [PMID:23612905]

936. Zhu K, Baudhuin LM, Hong G, Williams FS, Cristina KL, Kabarowski JH, Witte ON and Xu Y. (2001) Sphingosylphosphorylcholine and lysophosphatidylcholine are ligands for the $G$ protein-coupled receptor GPR4. J. Biol. Chem. 276: 41325-35 [PMID:11535583]

937. Zhu X, Huang D, Lan X, Tang C, Zhu Y, Han J, Huang W and Qian H. (2011) The first pharmacophore model for potent G protein-coupled receptor 119 agonist. Eur J Med Chem 46: 2901-7 [PMID:21524831]

938. Zingoni A, Rocchi M, Storlazzi CT, Bernardini G, Santoni A and Napolitano M. (1997) Isolation and chromosomal localization of GPR31, a human gene encoding a putative $\mathrm{G}$ protein-coupled receptor. Genomics 42: 519-23 [PMID:9205127]

939. Zohn IE, Klinger M, Karp X, Kirk H, Symons M, Chrzanowska-Wodnicka M, Der CJ and Kay RJ. (2000) 
G2A is an oncogenic G protein-coupled receptor. Oncogene 19: 3866-77 [PMID:10951580]

940. Zohn IE, Symons M, Chrzanowska-Wodnicka M, Westwick JK and Der CJ. (1998) Mas oncogene signaling and transformation require the small GTP-binding protein Rac. Mol. Cell. Biol. 18: 1225-35 [PMID:9488437]

941. Zucchi R, Chiellini G, Scanlan TS and Grandy DK. (2006) Trace amine-associated receptors and their ligands. Br. J. Pharmacol. 149: 967-78 [PMID:17088868]

942. Zylka MJ, Dong X, Southwell AL and Anderson DJ. (2003) Atypical expansion in mice of the sensory neuron-specific Mrg G protein-coupled receptor family. Proc. Natl. Acad. Sci. U.S.A. 100: 10043-8 [PMID:12909716]

943. Zylka MJ, Rice FL and Anderson DJ. (2005) Topographically distinct epidermal nociceptive circuits revealed by axonal tracers targeted to Mrgprd. Neuron 45: 17-25 [PMID:15629699] 